University of Louisville

ThinkIR: The University of Louisville's Institutional Repository

Electronic Theses and Dissertations

$12-2017$

\title{
"It teaches them to have a conversation in the real world" : an analysis of how identity performances shape classroom discussions.
}

Ashley Lauren Shelton Arnold

University of Louisville

Follow this and additional works at: https://ir.library.louisville.edu/etd

Part of the Curriculum and Instruction Commons, Language and Literacy Education Commons, Other Teacher Education and Professional Development Commons, Secondary Education Commons, and the Secondary Education and Teaching Commons

\section{Recommended Citation}

Shelton Arnold, Ashley Lauren, "'It teaches them to have a conversation in the real world" : an analysis of how identity performances shape classroom discussions." (2017). Electronic Theses and Dissertations. Paper 2835.

https://doi.org/10.18297/etd/2835

This Doctoral Dissertation is brought to you for free and open access by ThinkIR: The University of Louisville's Institutional Repository. It has been accepted for inclusion in Electronic Theses and Dissertations by an authorized administrator of ThinkIR: The University of Louisville's Institutional Repository. This title appears here courtesy of the author, who has retained all other copyrights. For more information, please contact thinkir@louisville.edu. 
“IT TEACHES THEM HOW TO HANDLE A CONVERSATION IN THE REAL WORLD": AN ANALYSIS OF HOW IDENTITY PERFORMANCES SHAPE CLASSROOM DISCUSSIONS

By

Ashley Lauren Shelton Arnold

B.A, Southern Illinois University Edwardsville, 2009

B.S., Southern Illinois University Edwardsville, 2009

M.A., London Metropolitan University, 2011

\begin{abstract}
A Dissertation
Submitted to the Faculty of the

College of Education and Human Development of the University of Louisville in Partial Fulfillment of the Requirements

for the Degree of

Doctor of Philosophy

in Curriculum and Instruction

Department of Middle and Secondary Education

University of Louisville

Louisville, Kentucky
\end{abstract}

December 2017 
Copyright 2017 by Ashley Lauren Shelton Arnold

All rights reserved. 

“IT TEACHES THEM HOW TO HANDLE A CONVERSATION IN THE REAL WORLD": AN ANALYSIS OF HOW IDENTITY PERFORMANCES SHAPE CLASSROOM DISCUSSIONS

By

Ashley Lauren Shelton Arnold

B.A, Southern Illinois University Edwardsville, 2009

B.S., Southern Illinois University Edwardsville, 2009

M.A., London Metropolitan University, 2011

A Dissertation Approved On

October 19, 2017

by the following Dissertation Committee

Dissertation Director

Dr. James Chisholm

Dissertation Co-Director

Dr. Penny Howell

Committee Member

Dr. Lori Norton-Meier

Committee Member

Dr. Andrea Olinger 


\section{DEDICATION}

This dissertation is dedicated to my parents

Dr. John Howard Shelton

And

Mrs. Cathryn Elaine Shelton

for providing me unconditional support and love throughout my educational journey. 


\section{ACKNOWLEDGEMENTS}

I owe many thanks to those that have supported me throughout this journey. This work would not have been completed without them.

First, I'd like to thank my committee members for providing thoughtful responses to my work at various stages during my dissertation. Your feedback was invaluable as I shaped my thinking. Most importantly, I'd like to thank my director, Dr. James Chisholm, for being the mentor that I hope to be for someone else one day. Your constructive criticism, purposeful feedback, and consistent encouragement made my writing that much better. Further, you have taught me many invaluable lessons, most notably that it's okay to say no every once and awhile. I hope that I can pay your mentorship forward within the field. I would also like to thank my family, who have consistently supported me from the very start of this journey. To my parents, who instilled a sense of drive within me that was instrumental in reaching this point, I cannot express enough gratitude. Your love and guidance have made me who I am today. I would also like to thank my brother for always

knowing how to make me laugh, even when stressed out. I'd like to thank my grandparents, aunts and uncles, and the Joyce children, for being my cheerleaders and reminding me how lucky I am to be surrounded by such a strong and loving bunch. And, I must thank Big Chief and Little Chief for their snorts and licks.

Finally, I want to thank my husband, Justin, for his understanding, patience, and encouragement throughout this process. Justin, you have never doubted me and, in turn, 
have pushed me to never doubt myself. I love you more than anything and cannot wait to see where life takes us next. 


\begin{abstract}
“IT TEACHES THEM HOW TO HANDLE A CONVERSATION IN THE REAL WORLD": AN ANALYSIS OF HOW IDENTITY PERFORMANCES SHAPE CLASSROOM DISCUSSIONS
\end{abstract}

Ashley L. Shelton Arnold

October 19, 2017

Although discussion has long played a role in classroom learning, recent focus on moving discussion away from the evaluative and toward the dialogic is key to understanding how discussion can be driven by multiple, shared understandings. Adopting a sociocultural perspective, this dissertation explores the ways in which identity performances shape one teacher and his students' participation in classroom discussions. The theoretical framework guiding this study draws on the relationship between discourse and identities construction, with further attention given to improvisations of identities, figured worlds, and the ways in which power shapes discourse. This dissertation argues that performed identities shape the ways in which discussion participants engaged in critical talk, particularly in how participants develop disagreement, engage in perspective taking, and foster power, agency, and voice in the classroom. Ultimately, this study suggests that it is imperative to consider the ways in which teachers navigate disagreement in the classroom, provide opportunities for students to participate in political discussion, and consider the ways in which participants' identities may shape discussion. 


\section{TABLE OF CONTENTS}

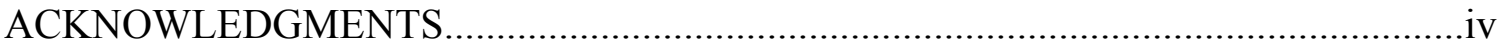

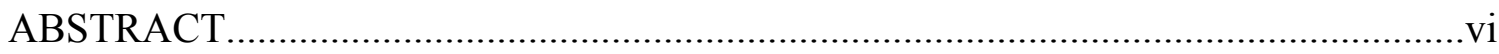

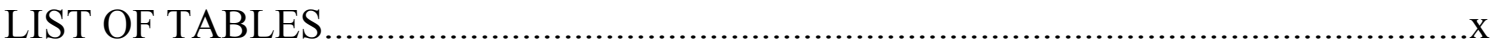

CHAPTER 1: NEGOTIATING IDENTITIES THROUGH DISCOURSE..............1

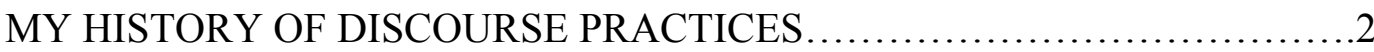

DISCOURSES OF TEACHING ......................................... 5

A SOCIOCULTURAL THEORY OF IDENTITY ..........................

STUDY RATIONALE............................................... 9

AN ETHNOGRAPHIC APPROACH..................................... 10

THE CHAPTERS ................................................... 12

CHAPTER 2: THEORETICAL FRAMEWORK AND LITERATURE REVIEW .......14

THEORETICAL FRAMEWORK.......................................14

LITERATURE REVIEW ..............................................24

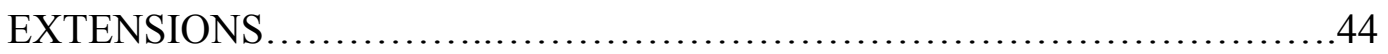

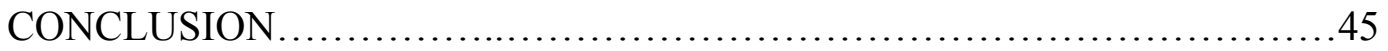

CHAPTER 3: METHODOLOGICAL RATIONALE ................................48

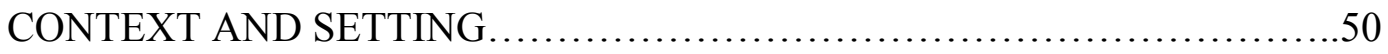

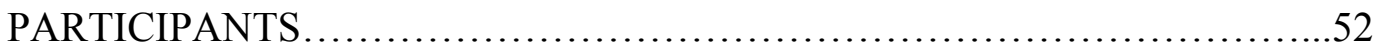

RESEARCH QUESTIONS..........................................54

DATA COLLECTION..................................................55 


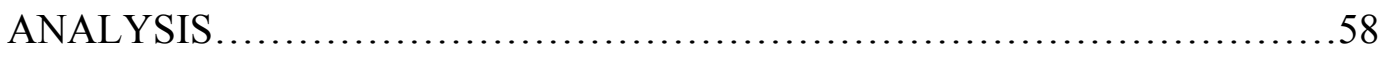

ROLE OF THE RESEARCHER...........................................63

CHAPTER 4: CONTEXTUAL PROFILES: THE COMMUNITY OF MARVILLE, MR. STARK, AND THE FOCAL STUDENTS .....................................67

THE COMMUNITY OF MARVILLE.....................................67

THE FOCAL STUDENTS AND TEACHER .................................. 83

CONCLUSION .............................................................. 125

CHAPTER 5: AN ANALYSIS OF CLASSROOM DISCUSSION ACROSS

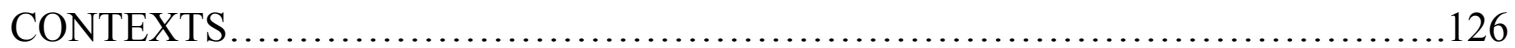

WHOLE CLASS DISCUSSION............................................

LITERATURE CIRCLE DISCUSSION....................................146

POLITICAL CIRCLE DISCUSSION.........................................162

CONSIDERING CRITICAL MOMENTS OF TALK........................182

CHAPTER 6: DISCUSSION AND CONCLUSION..................................185

IDENTITY PERFORMANCES ........................................187

POLITICAL TALK AND DISAGREEMENT..................................189

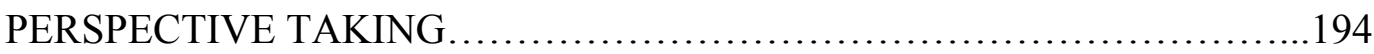

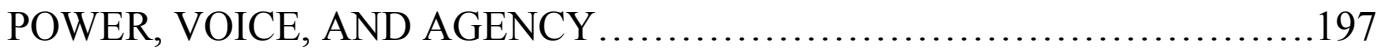

FUTURE DIRECTIONS FOR RESEARCH................................201

IMPLICATIONS FOR CLASSROOM TEACHING.........................204

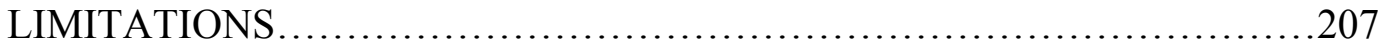

FINAL THOUGHTS........................................................208

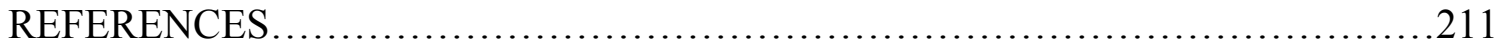


APPENDICES.

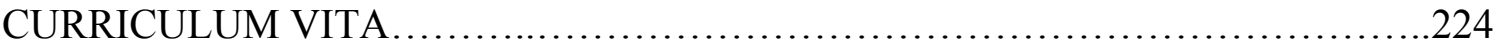




\section{LIST OF TABLES}

TABLE

PAGES

1. Marville High SchoolCareer Track.......................................50-51

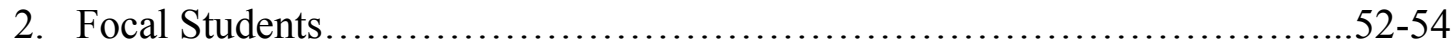

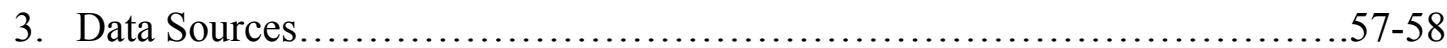

4. Mr. Stark Interview 1 Transcription Coding ................................60

5. Literature Circle Transcription Denotations..................................62

6. Field Notes Protocol...........................................................63 


\section{CHAPTER 1}

\section{NEGOTIATING IDENTITIES THROUGH DISCOURSE}

I preach that there are all kinds of truth, your truth and somebody else's. But behind all of them there is only one truth and that is that there's no truth.

\section{-Flannery O’Connor}

"There have been so many interpretations of the story that I'm not going to choose between them. Make your own choice. They contradict each other, the various choices. The only choice that really matters, the only interpretation of the story, if you want one, is your own. Not your teacher's, not your professor's, not mine, not a critic's, not some authority's. The only thing that matters is, first, the experience of being in the story, moving through it. Then any interpretation you like. If it's yours, then that's the right one..."

-William Golding, Lord of the Flies (1959) 


\section{My History of Discourse Practices}

Language tells my story, and that story is made up of a number of moments, conversations, histories, practices, contradictions, truths, half-truths, and lies. Language is one of my tools - I use language to construct my truths and write my story. Language becomes a way for me to communicate the myriad of identities that I perform through discourse, or "language-in-use" (Gee, 2014; Rymes, 2016). As a daughter and sister, I engage in the discourse of my family, which involves inside jokes, professional lingo, personal stories, and social markers. As a student, I take up the discourse of education, but one that is markedly different from the discourse of education that I engage in as a teacher; going from practitioner to researcher has caused me to not only utilize different components of language, but also to more carefully attend to the language that I use. As a woman, I take up the discourses of being a female, namely when I interact with others as a woman. The ways in which I use language around other women to say something about myself are largely different from the ways in which I take up the same practice around men. As a reader, I enter into the many discourses of literature, a vast system of discourses within discourses. The ways in which I take up these discourses are certainly not identical to that of others. However, as Bakhtin (1982) notes, "All words have the 'taste' of a profession, a genre, a tendency, a party, a particular work, a particular person, a generation, an age group, the day and hour. Each word tastes of the context and contexts in which it has lived its socially charged life; all words and forms are populated by intentions" (p. 293). When I respond to my father calling me "Elaine"; when I speak to my classmates about methodologies; when I discuss critical literacy with my students; 
when I engage in gossip with my girlfriends; and when I read Harry Potter and the Sorcerer's Stone (Rowling, 2001) or Love in the Time of Cholera (Marquez, 1985), my words and others are peppered with the social, cultural, and historical markers of belonging to these groups of discourse.

Holland, Lachicotte, Skinner, and Cain (2001) argue, "Selves are socially constructed through the mediation of powerful discourses..." (p. 26). My utterances are a way to assert who I am in any given situation, but also allow me to reconsider the ways in which others are participating in social discourses. As Bakhtin (1984) writes, "When we select words in the process of constructing an utterance, we by no means always take them from the system of language in their neutral, dictionary form. We usually take them from other utterances, and mainly from utterances that are kindred to ours in genre, that is, in theme, composition, or style" (p.87). Therefore, these utterances, along with my gestures, style, and appearance, occur as ways for me to enter into the multiple communities in which I participate; taken together, this is my "communicative repertoire" (Rymes, 2016).

I perform a number of different identities through my discourse practices. I use words to take up, assert, reject, and resist identities as they are available to me. As a young adult, I performed well in the sciences. I consistently scored high marks in my Biology courses, and therefore took up this "good at science" identity as I continued into college. The sciences were considered a "smart" field to belong in, and this identity was both imposed upon me and taken up by me. Further, as a woman within the sciences, I was identified by others as a standout surrounded by my male contemporaries. Because of this, a Discourse, or a way of being in a specific context, emerged as I engaged in talk 
with others to project a recognized identity that was "socially-situated" (Gee, 2014, p. 47) to explain the kind of person I wanted to promote and be in this context-namely a scientist. In this way, the Discourse of "doing" science became one in which I took part, but not one in which I always felt I belonged. However, I also simultaneously took up the discourse practices that I was a part of in my English courses. This identity was one that I readily took up — as a voracious reader, I longed to discuss authors who were important to me. Up until this point in my life, I had privileged the identity of reader and writer, avidly joining these discourses both in school and beyond. These identities often felt at odds with one another inside of me. I consistently negotiated my sense of self as I moved in and out of these competing discourse practices and others. This negotiation is commonplace for our society where performed identities are constantly being tried on and discarded (Hinchman \& Chandler-Olcott, 2006; Gee, 2006).

All of these discourse practices become a part of the myriad identities that make up my sense of self as I constantly negotiate who I am and who I want to be. My cultural background, my family, my histories, my relationships, and my life trajectory shape these practices. In turn, these practices shape the ways in which I enter discourses, negotiate my utterances within them, and construct and perform my identity in relation to them. I chose to begin this chapter by considering my own discourse history in order to better understand how identity performances shape my discourses as I promote who I am. Talk is an intrinsic part of how I show others who I am, who I want to be, and how I want them to perceive me to be. By constructing my own brief, albeit incomplete, trajectory of discourse, I note the both fluid and complicated nature of discourse, which will no doubt be explored in later chapters as I seek to explore others' identity performances and 
discourse practices. Within this dissertation, I take up research questions to consider how discourse shapes teachers and students, and their learning, in the classroom. Specifically, I seek to address the following:

1) How do identity performances shape the ways in which students and their teacher participate in classroom discussions?

2) How do these identity performances mediate the development of critical talk during classroom discussions?

\section{Discourses of Teaching}

For teachers, sense of self can be presented in a number of different ways. At any given time, teachers must perform roles such as: lesson planners and presenters, classroom managers, learners through professional development, administrators of the myriad paperwork responsibilities, and curriculum experts, amongst many others. Each of these roles is negotiated through the discourse practices that are embedded within them. For example, teachers must often negotiate, through language, teaching students how to analyze characters in The House on Mango Street (Cisneros, 1984) while simultaneously explicating the demands of curriculum mandates (essential questions, warm-ups and closings), all while intermittently monitoring, and sometimes maintaining, students' behavior and engagement. This means a constant shift across different identities as these roles come to fruition throughout their daily lives. These identities are performed within the social practice (Holland et al., 2001) of teaching. While teachers consider the social norms that are present within their profession, they are also trying to negotiate their own identities both within and separate from these practices. One's way of being can be negotiated by employing "interactive identity-based communication using language" 
(Gee, 2014, p. 24). In doing so, a Discourse (Gee, 2014) can be defined as performing, through language, a recognizable self. Therefore, a Discourse becomes a way of being in a specific context (i.e. a teacher within the larger world of education). For teachers, this is often a negotiated construct as they seek out the ways in which their beliefs and understandings about themselves and the profession fit in, or are at odds with, the dominant discourses surrounding their community. This may include their attitudes toward testing mandates, their opinions about what should and should not be taught in their classrooms, their pedagogical views towards assessment, or even the ways in which they believe their personality may or may not fit within their classrooms.

Others often position teachers within these roles around them, such as administration, parents, and students. Leander (2011) argues that positioning includes "activity and artifacts that contribute to another's identity, one's own identity, or to selfother relations...positions are offered, accepted, rejected, and otherwise continuously negotiated" (p. 116). For example, at the site of my study, teachers were required to attend a professional development around the book The Fundamental 5: The Formula for Quality Instruction (Cain \& Laird, 2011). Not only did the school invest heavily in the approaches within this book by having Sean Cain provide the professional development himself; the school also put into place expectations that teachers were adhering to these beliefs in their day-to-day teaching practices. These forces and more, such as past experiences, cultural backgrounds, relationships with learning, interactions with students, and pedagogical beliefs, inform the identities that teachers perform (Agee, 2006; Schappe, 2015; Skerrett, 2009). 
While it may seem that these forces would work in tandem with one another, this is not necessarily the case. In fact, teachers may feel that the abundance of hats they must wear are at odds with their own understanding of themselves (Bickmore, Smagorinsky, \& O’Donnell-Allen, 2005). While much research has broadly taken into consideration how personal and professional experiences shape identities, this study aims to contribute to a growing body of scholarly work that studies the local, every day practices in which teachers may perform these identities, particularly through discourse (Alsup, 2006;

Flowerdew \& Wang, 2015; Rumenapp, 2016; Schieble, Vetter, \& Meacham, 2015). New teachers in particular are subject to the negotiation of the many roles they must fulfill (Alsup, 2006; Pearce \& Morrison, 2011). This negotiation can come to fruition in competing discourses as teachers seek out their own construction of identity within the larger realm of education.

\section{A Sociocultural Theory of Identity}

Identities are socially and culturally constructed selves that are performed in many different contexts and for many different purposes. In thinking of the discourses that teachers take up throughout their educational careers, the identities that they perform through these discourses cannot be neglected. As Gee (2006) argued, "Identities today take work. A person is expected to craft them out of available social and cultural resources. A person is expected to take on new identities through life, dropping some, changing others, and taking on new ones" (p. 166). People constantly perform identities through discourse as they negotiate their sense of self in any given context-i.e. attending a professional development as a teacher, answering questions in class, or in the case of this study participating in different contexts of classroom discussion. 
I believe that identities are formed in, and respond to, the worlds in which individuals move. These figured worlds provide both context and meaning for the social relationships that occur within them. Just as Discourses are created to inform others of one's identity in any given situation, these Discourses can belong in, or be at odds with, a figured world, defined as: "a picture of a simplified world that captures what is taken to be typical or normal" (Gee, 2014, p. 89). Holland et al. (2003) further Gee's understanding by stating that a figured world is "a socially and culturally constructed realm of interpretation in which particular characters and actors are recognized, significance is assigned to certain acts, and particular outcomes are valued over others. People create figured worlds as a way to normalize "typical stories" (Gee, 2014, p. 89) that help them navigate and interpret the world around them. Figured worlds can include "participants, activities, ways of interacting, forms of language, people, objects, environments, and institutions, as well as values..." (Gee, 2014, p. 90). A figured world can be created in relation to occurrences within it (Holland et al., 2001). For example, a teacher Discourse or student Discourse can be carried out within the figured world of education. The social position of teacher or student is "named and conducted" (p. 60) as a Discourse within the figured world of education in order for one to negotiate his or her self within that world. Researching how teachers and students create Discourses to navigate their identities within a figured world, such as that of education, can increase understanding of daily classroom practices and the ways in which they shape both students' and a teacher's identities alike. Further, agency and power are intricately tied into the identities that individuals inhabit within figured worlds. Lewis, Enciso, and Moje (2007) describe power as "produced and enacted in and through discourses, relationships, 
activities, spaces and times by people as they compete for access to and control of resources, tools, and identities" (p. 17). These ways of acquiring power are contextually situated within the figured worlds that are populated by many identifiable selves. To revisit the ways in which teachers take up a myriad of identities within the classroom, a consideration for how power plays a role in the performance of these identities is imperative. Teachers may take on identities, through discourse, as they take up their roles as educators, consider when to push back against institutional mandates and when to accept them, or simply as a means of negotiating classroom practices with students.

\section{Study Rationale}

Within the figured worlds that dominate education, Hall (1996) argues that a privileged view of identity as stable is valued (qtd. in Lewis \& del Valle, 2008, p. 310). This extends to views of literacy, as well. This understanding of identity and literacy is directly at odds with my belief that a number of identities can be performed at any given time, which furthers the argument that teachers and students must learn to expertly negotiate their many identities even if they may not align with the privileged practices they must inhabit in a school setting (Glenn \& Ginsberg, 2016). Students and teachers are often labeled or positioned within education, both formally and informally; they may carry these "stable" labels with them throughout their educational careers, and these labels can often define who they are to others within this setting as they may perform identities through discourse. For example, students who are formally labeled or positioned as resistant or struggling readers may equate these identities with their classroom experiences (Glenn \& Ginsberg, 2016); informally, students may be labeled by their peers and perform those identities within the classroom (Chisholm \& Olinger, 
2017). As Moore and Cunningham (2006) assert, "As youth internalize various views of themselves from their interactions, they begin to compare, contrast, and play with them, seizing opportunities for combinations and modifications. They eventually take on and act out identities that position themselves in various ways. In some cases these actions foster academic identities; in other cases they are impediments" (p. 139). Because of this various positioning of identities, I question how students' identities are performed when they are given the opportunity within a classroom to participate in whole class discussion as well as circle discussion for the first time. Further, I question how a teacher negotiates classroom discussion, and whether tensions exist in trying to provide students with a space in which they are able to perform a myriad of identities as disagreement arises during each of these discussion contexts. This study seeks to explore those questions as I deeply immerse myself into one classroom where a teacher seeks to provide his students with the opportunity to participate in classroom discussion in which students begin to navigate disagreement and contentious talk.

\section{An Ethnographic Approach}

LeCompte and Schensul (2010) denote two purposes in conducting ethnographic research: "understanding socio/cultural problems in communities or institutions" and "using the research to develop and assess approaches to solving problems or helping to bring about positive change in institutions or communities" (p. 9). At the center of discourse is a sociocultural understanding that speaking is used as a mediator for thinking, and therefore talk becomes the tool speakers use to navigate those understandings (Vygotsky, 1978). However, when talk becomes a barrier for, is not privileged by, or is not considered valuable by speakers in a classroom community during 
discussion in general, or literature discussions, researchers must consider how this shapes the performed identities of participants, as well as the labels that they carry with them.

In this dissertation, I adopt an ethnographic approach as I seek to understand how one teacher and his students' identity performances shape discussion within a particular classroom. I explore these identity performances across three discourse contexts: whole class discussion, literature circle discussion, and political discussion. Further, I investigate how these identity performances shape the ways in which participants' discussions develop political talk, consider multiple perspectives, and allow for voice in the classroom. Particularly, I hope to better understand how these identity performances through discourse mediate learning in the atypically figured world of Mr. Stark's classroom. I consider Mr. Stark's classroom to be an atypically figured world in that there are tensions between the type of teacher that he wants to be and the figured world of education that he believes he needs to fit within; in this way, Mr. Stark's classroom presents an unusual space in which he negotiates these tensions through discourse. By considering how talk develops within and across the contexts above in studying the local, everyday discourse practices in this classroom, I hope to better understand how both students and teachers negotiate their many identities across different discussion contexts. An understanding of these practices may speak to future classroom instruction as educators consider or reconsider the ways in which talk in their classrooms facilitates or disrupts learning for students. 


\section{The Chapters}

In this chapter, I introduce the broad ideas and theories that ground this dissertation. Particularly, this chapter briefly discussed the main components of my theoretical framework: discourse and identities construction.

In chapter 2, I provide a theoretical framework that outlines my argument for conducting this study. This framework capitalizes on theory surrounding discourse, identities construction, figured worlds, and power and agency, which are all constructs that guided my thinking as I conducted this research. In addition, I provide a brief overview of the literature that attends to the history and current climate of classroom discussions, paying special attention to the ways in which identities shape, and are shaped by, classroom discussions. More particularly, I focus this review on studies that explore how students engage in political talk/disagreement, perspective taking, and the promotion or silencing of voice and agency during classroom discussion.

In chapter 3, I present my methodological rationale for taking up an ethnographic approach towards data collection in the classroom. I follow this with a discussion of my research questions, the site and participants of my study, and the methods for data collection. I then turn to a discussion of the ways in which I collected and analyzed data. Finally, I attend to my stance as a researcher within this study.

Chapters 4 and 5 contain the findings from this study. Chapter 4 provides contextual profiles of the community of Marville, Mr. Stark, and the focal students. These contextual profiles are analyses of the identities that Mr. Stark and his students described during individual interviews coupled with my own observations. In chapter 5, I analyze the ways in which both Mr. Stark and his students perform these identities 
through three discussion contexts: whole class discussion, literature circle discussion, and political discussion. My rationale for writing two distinct chapters is that an understanding of the beliefs that participants have about themselves and how they want others to see them is first necessary before considering the ways in which they participate in discussion by performing these identities. Further, I conducted analysis of the contextual profiles before I analyzed classroom discussion; therefore, the analysis of identity performances informed the analysis of classroom discussion.

Finally in chapter 6 , I discuss the analysis from the previous chapters, paying careful attention to the ways in which identity performances shaped classroom discussion as students developed political talk and disagreement, considered multiple perspectives, and gained voice and agency within the classroom. I then argue for implications in future research and teaching before discussing limitations to this study. 


\section{CHAPTER 2}

\section{THEORETICAL FRAMEWORK AND LITERATURE REVIEW}

\section{Theoretical Framework}

The theoretical framework guiding this study draws on a number of constructs. I begin by articulating the ways in which both discourses and identities are constructed, and post the relationship between discourse, discussion and identity performances. I then move into a discussion of improvisations of identities, figured worlds of education, and the ways in which power shapes discourse.

\section{Discourse Construction}

Dialogism, a theory arising from the work of Bakhtin (1986), concerns itself with the ways in which expression, specifically the nature of discussion, is a reciprocal process whereby speakers' statements take into account previous speakers' utterances as well as future speakers' responses. Each utterance is both addressed from one speaker to another (Bakhtin, p. 95) as well as expectant in response. As Bakhtin (1986) argues:

When we select words in the process of constructing an utterance, we by no means always take them from the system of language in their neutral, dictionary form. We usually take them from other utterances, and mainly from utterances that are kindred to ours in genre, that is, in theme, composition, or style. (p. 87) 
Therefore, utterances can be seen as both historically and culturally shaped, but also spontaneous in nature. Cazden and Beck (2003) stated, "Learning new ways with words entails taking on new interactional roles and the new identities they create and express" (p. 166). Bakhtin described this process as assimilation of words, whereby speakers rely on others' words as well as "varying degrees of 'our-own-ness"” (p. 89) in constructing utterances noting, "these words carry with them their own expression, their own evaluative tone, which we assimilate, re-work, and re-accentuate" (p. 89). This assimilation comprises "language-in-use" (Rymes, 2016) for speakers. Speakers dwell on a number of different resources, including the social context in which they are speaking, the interactional relationship they have with others, and their own agency. In this fashion, speakers perform identities through discourse. Language, therefore, allows speakers to take on social identities (Gee, 2014). Within this argument, dialogic discussion is both heteroglossic, or mixed with many others' words and meanings, and polyphonic, inherent of many styles, references and assumptions which aren't "owned” by the speaker (Bakhtin, 1981). Lewis, Enciso, and Moje (2007) describe this as Bakhtin's conversation surrounding "disequilibrium in relation to identity and discourse" (p. 7). In other words, speakers are constantly negotiating themselves and their performed identities during discussion as they take up and discard the many available language resources they have in order to be a specific person, during a specific context, at a specific time (see Figure $1)$. 
Speakers draw on a number of

available resources in order to engage in discourse.

Teachers and students perform identities by enacting through

talk a recognizable sense of self

that may or may not be taken up by others.

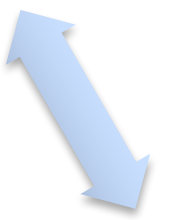

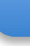

Discourses enacted are used within discussion as teachers and students make claims about what they know and who they are.

Figure 1: Relationship Between Discourse, Discussion, and Identity Performances

The ways in which these utterances are shaped inform the discourse that occurs within discussion in the ELA classroom. To study dialogic discussion is to study one form of communication in the classroom. Cazden (2001) stated three ways in which communication through language is at the center of school: oral language is used both by teachers to educate and by students to demonstrate their learning; classrooms are crowded environments in which talk occurs normally and simultaneously, and in which teachers regulate talk; and, language is a marker of identities of participants (p. 2). Thus, language use in classroom discussions is situated — it is not neutral but "populated-overpopulated - by the intentions of others" (Bakhtin, 1986, p. 294). By situated, discussion can be thought of as dynamic. Speakers within discussion have a number of intentions at any given time and discussion provides them with an opportunity to make those intentions known. For example, a speaker may choose to reject an understanding of literature during discussion, and they may perform an identity of resistance in order to 
make that intention known. In this way, language can be used to take up different ways of being at various times/places and for various reasons (Gee, 2014, p. 3). As in the example above, when students utilize language during discussion, they are making claims about what they know and who they are at that given time. Dialogic discussion, by nature, involves providing students with opportunities to respond to authentic questions, engaging in discussion openly amongst peers, and teachers taking up students' questions to build on and continue discussion (Applebee et. al., 2003). Language within discussion is used to "build things in the world, to engage in world building, and to keep the social world going" (Gee, 2014, p. 31). From a sociocultural perspective, language becomes a mediator for thinking as students co-construct knowledge with one another during discussion. Therefore participants shape the nature of discussion, and it may provide an opportunity for participants to perform identities that are otherwise marginalized in that space. Further, dialogic discussion can allow for authentic and open conversation. However, moving discussion into a truly dialogic space is not without its complications, and should not be thought of as an easy and swift occurrence, but rather something that happens over time, affected by the participants as well as the space in which they inhabit (Bakhtin, 1986).

\section{Identities Construction}

Identities allow individuals to make meaning and create understanding of the world around them. Identities also dictate the interactions humans have with one another, allowing them to respond and adapt to situations. Indeed, identities are a way to combine one's social and cultural world with one's personal world (Holland et. al., 2003). These "self understandings" (Holland et al., p. 3) are ways for individuals to negotiate the 
worlds in which they are a part. Constructed worlds, according to Holland and colleagues, are "recognized fields or frames of social life..." (p. 7). In other words, individual identities are in constant flux; individuals are composed of a number of inconsistent identities and views of self which are embodied and performed across different social structures, at different times, for different reasons (Holland et al., 1998; Moore \& Cunningham, 2006). Identities become ways of "mediating agency" (Holland et al., p. 4) for students and teachers as they participate in learning processes, such as discussion. In doing so, a social construction of the self is created within an institution, whereby "interactive identity-based communication using language" (Gee, 2012, p. 24) can occur; specifically from a literacy lens, this identity recognition is imperative for students to understand that literacy is not an exclusionary process. This follows a view of the socially constructed self, which sees discourse as a way to convey what we say and make claims about who we are (Gee, 2001; Holland et al. 1998). Holland and colleagues denote three tenets to describe the socially constructed self: selves which are socially constructed are neither universally identified nor unchanging, selves are "socially embedded practices", and production of self occurs at multiple sites (p. 28). Therefore learning, from a sociocultural perspective, involves relationships and practices between participants (Moje \& Luke, 2009, p. 416). In addition, Gee (2001) notes that identities are those selves that are recognized by others. A number of discourses may be taken up in order to inform the identities that one wants to project at any given time. Identity construction through discussion allows for a taking up of discourses in many different contexts as they become available (Holland \& Lave, 2001). 


\section{Improvisations of Identities}

Because an individual's identities are fluid, moments occur in which an individual must take up a new understanding of self, or improvisation. Improvisations can be described as moments where "our past, brought to the present as habitus, meets with a particular combination of circumstances and conditions for which we have no set response" (Holland et al., 2003, pp. 17-18). To further account for this understanding of improvisations, Holland et al. tell the story of Gyanumaya, a Nepalese woman who climbed the side of a house, in which she was not welcomed due to her position within a social caste system, to gain entrance in an acceptable way. Holland and colleagues argue that Gyanumaya improvised her identity within this process as a way to react to her positioning within society, using her climb as a way to both conform to the larger

Discourse of a caste society, while at the same time improvising an identity that allowed her access into an otherwise forbidden place. Improvisations allow for an individual to take up an altered identity in the moment that may carry on with them or be dispelled of, as deferring to that identity within the moment does not mean one accepts this self as permanent. These improvisations can be seen as moments where the cultural and the personal meld together as one both reacts to the world around them while negotiating the self. When Gyanumaya chose to climb the side of the house, rather than choosing not to pursue entrance, she was performing an identity that was imposed on her by the social caste she lived within. Improvisation occurs in many different social worlds, including the institution of the classroom. In fact, Lewis and del Valle (2009) noted that students improvise their literate identities in relation to their own race, gender, and economics ( $\mathrm{p}$. 317). These improvisations, or performances, occur as students navigate the many literate 
identities available to them during school-sanctioned practices (Glenn \& Ginsburg, 2016). These improvisations allow or deny students' access to institutionalized forms of literacy (Hall, 2016).

\section{Figured Worlds of Education}

Just as discourses are taken up to inform others of one's identity in any given situation, these discourses can belong in, or be at odds with, a figured world: "a picture of a simplified world that captures what is taken to be typical or normal" (Gee, 2014, p. 89). Holland et al. further this explanation by stating that a figured world is "a socially and culturally constructed realm of interpretation in which particular characters and actors are recognized, significance is assigned to certain acts, and particular outcomes are valued over others. People create figured worlds as a way to normalize "typical stories" (Gee, p. 89) that help one navigate and interpret the world around them. Figured worlds can include "participants, activities, ways of interacting, forms of language, people, objects, environments, and institutions, as well as values..." (p. 90). A figured world can be created in relation to occurrences within it (Holland et al., 2003). For example, a teacher or student Discourse (Gee), or socially enacted and recognized identity, can be carried out within the figured world of education as participants engage in discourse during discussion. As Gee writes, "The identities are socially significant because various and different social groups construct, construe, use, negotiated, contest, and transform them in the world and in history" (p. 25). The social position of teacher or student is "named and conducted" (p. 60) as a Discourse within the figured world of education as one negotiates his or her self within that world. Researching how teachers and students create Discourses to navigate their identities within figured worlds, such as that of education, 
can increase understanding of daily classroom practices and their effects on both students and teacher alike.

Identities are formed in, and respond to, the worlds within which individuals move. For example, the figured world of the caste society in which Gyanumaya lived dictated her actions of climbing up the house, even though extenuating circumstances most likely would have allowed her to enter through the doorway. These figured worlds provide both context and meaning for the social relationships that occur within them. Holland et. al. describe figured worlds in the following ways: they are historical and develop over time; they are social and position those that populate them; they organize those within them relationally; those that populate them have identities in relation to them (p. 41). It is important to note that agency and power are both intricately tied into figured worlds. Holland and colleagues state that one's position and status within a figured world is identified (p. 61). Lewis, Enciso, and Moje (2007) describe power as "produced and enacted in and through discourses, relationships, activities, spaces and times by people as they compete for access to and control of resources, tools, and identities" (p. 17). These ways of acquiring power and agency are contextually situated within the figured worlds that are populated by many identifiable selves. As Moore and Cunningham (2006) state, "people simultaneously (a) decide how they will act, (b) are influenced and limited in their decisions by their contexts, and (c) contribute to contexts that influence and limit how they will act" (p. 135). Because of this simultaneous fashioning, power, agency, and the context in which they occur (in the case of this study, discussion) are inextricably linked as people participate in a recursive relationship within their environments. 


\section{Power Structures in Discourse}

A number of different power structures operate within discourse, including who gets speaking rights, what identities are and are not performed, and how discourses are taken up, revised, or discarded by participants. Holland et al. (2003) asserted, "Selves are socially constructed through the mediation of powerful discourses...” (p. 26). Gee (2014) built on this statement by noting that one's sense of self can be negotiated by employing “interactive identity-based communication using language" (p. 24). In doing so, a Discourse (Gee, 2014) can be demarcated by enacting through language a recognizable self that characteristically defines an identity understanding. A Discourse emerges as a projected identity that is "socially-situated" (p. 47) to explain the kind of person one wants to promote and be in any given context. This sense of self becomes a performance that is embedded within the social practice (Holland et al., 2003) of discussion. Therefore, a Discourse becomes a way of promoting and performing an identity within a community of practice, i.e. students' utterances during discussion. When students participate in discussions, they become part of discourse communities within their classroom. Lewis et al. (2007) defined discourse communities (and, in effect, Discourses) as "groupings of people_ not only face-to-face or actual in-the-moment groupings, but also ideational groupings across time and space — that share ways of knowing, thinking, believing, acting, and communicating” (p.16). An inherent aspect of discourse communities is the power structures in which they operate. Power is "produced and enacted through discourses" (Lewis et al., 2007, p. 17) as students perform different identities through participation in literature discussions. Identities, in this sense, are ways for students to mediate agency (Holland et al., 2003; Lewis et al., 2007), as they both take 
up and resist discourses that are provided to them. As Cazden and Beck (2003) argued, "There is more to speaking rights than simply getting a turn, however; there is also the question of which topics are picked up and developed and whose ideas thereby 'get the floor"' (p. 176). Power, identity, and agency are intrinsic components as students participate in (or don't), are marginalized within (or viewed as "experts"), or redefine (or create new) classroom discourse communities within discussions surrounding literature.

Lewis, Enciso, and Moje (2007) argued that for students to be given the opportunity to learn the following conditions must be in place:

First, it requires that one's subjectivity and the identities one enacts be recognized and accepted as valid and worthwhile, even when they may conflict with those subjectivities and identities typically built in the learning space. Opportunity to learn also requires that participants have the space and support for agentic action, that is, that learners have opportunities to make and remake themselves, their identities, their discursive toolkits, and their relationships on the basis of the new ideas, practices, or discourses learned through their participation in a learning activity. (p. 20)

Within these constructs, discussion is comprised of both what students bring into discussion as well as the ways in which they learn to participate within discussion. Students enter into the space of discussion with a myriad of identities, as well as take up and discard new identities during discussion. Further, the material on which discussion takes place can shape the ways in which these identities are performed, especially if these topics are highly contentious or disagreeable. As Holland and Lave (2001) assert, "Enmeshed in dialogues across difference, often sharply contentious ones, over which 
they lack total "say," persons are ever open to radicalization and the experience of heightened structural apprehension, or to its partial opposite, incorporation of the other into the 'I for myself'" (p. 18). Because of this, participation in discussion can be inherently transformative or disruptive for students when they are provided as they question, adopt, change, submit to or reject the beliefs and practices thrust upon them.

\section{Literature Review}

Within this study, I contend that identities, and specifically identities performances, shape classroom discussion. In conducting the literature review, I first sought out studies that included discussion of students' and teachers' identities formations. For this reason, I begin this literature review below with a broad conversation concerning the scholarship about factors that might shape teachers' and students' identities with regard to the contextual analysis of identities in chapter 4. I then compiled literature that was concerned with discussion in the classroom; particularly I began by reading seminal literature that is widely cited in the field. As themes began to emerge during analysis, including critical stances, perspective taking, and agency, voice, and power, I revisited the literature to include studies on these components of discussion. Below, I will elaborate on the scholarship pertaining to classroom discussions that examines critical stances, perspective taking, and power, agency, and voice. Identities, as an underlying theoretical component of this study, are a strand found throughout this literature. Finally, I will posit the ways in which this research seeks to extend this body of knowledge by bridging the ways in which participation in discussion is shaped by students' and their teacher's identity performances in the classroom. 


\section{Shaping of Identities}

As theorized above, identities allow individuals to make meaning and create understanding of the world around them. Identities also dictates the interactions humans have with one another, allowing them to respond and adapt to situations. Skerrett (2012) noted, "Identities develop over time, are influenced by numerous social and cultural experiences, and are expressed according to social and cultural norms. Identity is neither static nor singular" (p. 63). When considered within education, particularly in interactions between teachers and students in a classroom, the ways in which identities are performed across contexts may speak to the ways in which both teaching and learning occur (Hall, 2016; Sherry, 2014). While identity is seen as an important lens for research in order to more deeply understand the nature of school communities, it has taken on many different meanings throughout literature (Gee, 2001). Gee (2001) noted that identity is also constantly shifting in terms of positioning within social situations. As Wortham (2004) argued, "such local identities emerge as teachers and students draw on institutional resources, habitual classroom roles, the curriculum, and other resources to position students in recognizable ways." (p. 165). Therefore, knowing that both teachers and students perform a number of identities in the classroom, subsequently constructing and adopting new identities within educational settings, realizing how these identities promote and interact with students' educational experience is of utmost importance.

Studies suggest that many different facets of teachers' lives contribute to their identities make-up, including past experiences, teacher training, school climate/administration, students, and growth (Cook, 2009, Early \& Shagoury, 2010; 
Flores \& Day, 2006; Kreber, 2010). Coupled together, these aspects inform the ways in which teachers perform identities in the classroom as they negotiate the many different aspects of the profession. More often than not, teachers cited their students in consideration of their identity formation. Teachers believed students shaped their identities in terms of how they negotiate their authoritative role in the classroom, particularly in understanding how and why to set boundaries with students (Cook, 2009). Further, caring for students, and focusing on the holistic student, were also found to play a central role in how teachers performed identities in the classroom (Flores \& Day, 2006; O'Connor, 2008). These identity performances also included preparing students for the real world (Kreber, 2010), the ways in which students responded to teachers' performed identities, and the ways in which students were learning within the classroom (Early \& Shagoury, 2010).

While student beliefs do shape their classroom identities, engagement, student choice, and teachers are all heavy influences suggested throughout the literature (Compton-Lilly, 2006; Smith, 2008; Faircloth, 2009, 2012; Skerrett, 2012). One area of education that teacher identities can particularly shape is students' academic identities. Students react and respond to the identities that teachers perform within the classroom. They do so by also performing their own identities in the classroom as they interact with the performed identities of others. For example, Skerrett (2012) found that student's identities were shaped by teachers positioning them either by the labels they were given in their educational experiences, or by rejecting the label in favor of more positive identities labels. On the other hand, researchers have also found that when teachers placed identities on their students based on the context of the class, students rejected or 
manipulated those identities when they did not feel aligned with them (Smith, 2008; Wortham, 2004). Yet, Skerrett's results indicated that when students were given the opportunity to explore their academic identities through what they believed to be relative literacy practices (i.e. the opportunity to read authentic texts in which they could identify or the opportunity to build on out-of-school literacy practices in school), they were able to gain a stronger sense of their own representation of themselves. In fact, other research has indicated students were more apt to negotiate their identities when they could see themselves within the learning process (Faircloth, 2012).

Overall, both teachers and students have a dialectical relationship with one another through their identity performances; this relationship shapes the learning experiences that both students and teachers participate within in the classroom. Without an understanding of how identities are performed within the classroom, an understanding of the formation of the learning process as a whole becomes only surface level. By seeking to explore the role of identities within the classroom, and the discourses taken up within that space, a deeper understanding of how teachers enact their role as educators, and how students enact their role as learners, can be gained (Williams, 2006). The literature below seeks to expand on these understandings of the ways in which students' and teachers' identities are shaped by considering how those identities are in turn performed during classroom discussions.

\section{Classroom Discussion}

Within many English Language Arts (ELA) classrooms, students "do" school, going through the typical motions of listening to a lecture, responding to texts via worksheets, carrying out homework assignments that involve more worksheets, and 
returning to continue the cycle the next day (Miller, Knipps, \& Goss, 2013; Pope, 2003). One opportunity that scholars note is grossly lacking in this routine is the possibility for students to participate in what they call "authentic" discussion (Nystrand \& Gamoran, 1990; Applebee, Langer, Nystrand, \& Gamoran, 2003). In contrast, much of the discourse that takes place in classrooms is recitation - the teacher initiates a question, students respond to the question, and the teacher evaluates that response before revisiting the cycle, often called I-R-E, over again (Applebee et. al., 2003; Cazden, 2001; Maloch \& Bomer, 2012; Nystrand \& Gamoran, 1991). However, teachers are now required to provide students with more opportunities to "learn by doing"; rather than providing knowledge as transmission and memorization, teachers are asked to open up discussion in their classrooms in order to stimulate more deeply embedded thinking, while students are asked to respond to their peers and critically examine texts (Cazden \& Beck, 2003). Applebee et al. (2003) argue that when students are involved in dialogic discussions where teachers have high academic demands related to their participation, deeper literacy learning can occur.

From a sociocultural perspective, discussion should involve students considering how they can personally connect to the texts before them. Smagorinsky (2001) described this as a "joint accomplishment, not just of readers and texts but of readers and texts in conjunction with the cultural practices through which both have been produced and through which the two become engaged (p. 141)" (cited in Thein, 2009). As Galda and Beach (2001) noted, "Texts, readers, and contexts, each inseparable from the other, are also inseparable from the larger contexts in which they are enacted" (p. 66). Exploring the cultural practices that students employ when they participate in dialogic literature 
discussions will allow for a deeper understanding of their responses during discussions centered on literature (Thein, 2009). Galda and Beach (2001) delineated a number of characteristics of readers' response to text including: readers have expectations of characters' behavior in texts based on their own cultural contexts; readers respond to text based on the social norms they perceive to be functioning within a text; readers may resist social norms they perceive within a text; and finally, readers employ language to construct both their lived worlds and the worlds they perceive within the text.

Studies on the nature of discussion in the classroom are situated within a number of diverse topics, including comprehension (Nystrand, 2006; Hall, 2012), race (Rogers, 2002; Sutherland, 2007), identity (Thein, 2009), social class (Thein, Guise, \& Sloan, 2011), positioning (Bean \& Moni, 2003; Clarke, 2006) and power (Hinchman \& Young, 2001). However, this literature review will focus specifically on the ways in which critical stances, perspective taking, and power, agency, and voice have been studied. First, I provide a brief overview detailing seminal studies regarding the nature of classroom discussion. Then, I focus on discourse studies that reflect the themes of critical stances, perspective taking, and power, agency and voice. This review is in no way exhaustive; however, it highlights a number of key studies that have contributed to scholarship surrounding the nature of adolescents' literature discussions.

\section{Seminal Studies}

In their groundbreaking study, Nystrand and Gamoran (1991) found that in high quality classroom discussion, both students and teachers participated in uptake, where teachers shape their questions around students' previous responses in order to allow for a streamlined conversation. Further, they noted other markers of high quality conversation 
to include teachers' consideration of atypical conversational directions and turntaking, where the teacher joins in as a co-constructor of knowledge rather than an evaluative authority. However, this can be complicated by students' cultural backgrounds, beliefs, and relationships with one another because teachers might be reticent to adopt a dialogic discussion stance in the classroom when students would take up conversations that might seem too "risky" to talk about in school (Christoph \& Nystrand, 2001). Further, teachers might problematize the notion of discussion if they believe that social relationships are guiding talk. In fact, Lewis's (1997) yearlong study in a $5^{\text {th }} / 6^{\text {th }}$ grade split classroom highlights the complicated nature of social positioning in literature discussions. Students in this classroom performed a number of identities to communicate social markers as they took up discourses both publicly in discussion and privately through other classwork. Often, these performed identities were at tension with one another as students negotiated who they were and how they wanted to present themselves within that space. Yet, research has shown that providing students with the opportunity to participate in discussion is much beneficial, even beyond discussion itself. Applebee, Langer, Nystrand, and Gamoran's (2003) largescale study indicated that when students were given the opportunity to participate in classroom discussions they were able to increasingly take on more challenging and independent literacy tasks, such as writing. While many of these seminal studies focused on discussions that took place on literature, other studies have turned toward discussion of real world ideas and texts. Most notable in relation to this work is Hess and McAvoy's (2014) four-year longitudinal study that examined the ways in which political discussion occurred in high school social studies classrooms, and how that discussion shaped the ways in which students engaged 
with politics in the future. In classrooms where students come from various races and social classes, teachers often struggle with the social landscape this heterogeneity creates and how that might shape classroom discussions. Further, political polarization, or moments where political extreme occurs, affects teachers' actions and pedagogical choices. The authors homed in on three teacher case studies: one who sought to motivate students to participate in a democratic society, one who sought to develop political friendships, and one who sought to encourage students to critically reflect the intersection of their political and spiritual beliefs. Ultimately, they contend that teachers must use their professional judgement as they consider how to present controversial issues, how to balance the tensions of classroom climate and political controversies, and whether teachers should disclose their political views to their students.

\section{Critical Stances}

Scholarship has continued to expand on the ways in which students participate in discussion, specifically in how students take up critical stances during discussion. When students are able to adopt critical stances during literature discussion, they may explore the ways in which a text positions them, how voice plays a role both in the text and in students' responses, and imagine alternate possibilities for those within the text (Bean \& Moni, 2003). Sutherland's (2007) study builds on these notions as she explored the ways in which Black female students participated in small literature discussions to engage in identities construction. She found that as these students participated in discussion surrounding Toni Morrison's The Bluest Eye, two dominating themes prevailed: “a) a Eurocentric view of beauty acts as a boundary in Black women's lives, and b) others' assumptions about who they are — thus how they will and should behave — acts as a 
boundary" (p. 380). As discussion centered on these two themes, the students both performed and co-performed identities of resistance in the process. discussion was also used to explore a counter story to the one that developed within the novel as they made sense of the text by challenging privileged discourses. As students learn to connect their worlds with the literature they are discussing, they are able to critically examine texts and offer both examples and counterexamples of exploration through open-ended talk (Juzwik, Nystrand, Kelly, \& Sherry, 2008)

However, the notion of taking a critical stance in response to literature can be problematized. Through students' dialogic literature discussions of Bastard Out of Carolina, researchers found that students' attempts to critically discuss the novel's themes of poverty, class stereotypes, and abuse were actually subverted when students tried to normalize the characters' experiences in relation to their own experiences (Thein, Guise, \& Sloan, 2011). Importantly, teachers should not assume that students will always take up a critical stance when given the opportunity for critical discussion in response to a novel that calls into question political and social norms. In fact, students may adopt the dominant discourses that are privileged in discussion, thereby abandoning their critical readings of a text (Pace, 2006). This subversion of the critical stance might also occur when students ascribe to cultural models in which they have access to frame their performed identities in literature discussions in the classroom (Thein, 2011). When school texts do not allow for students to identify with them, students may participate in discussion ambivalently or negatively. Faircloth (2012) similarly notes that students feel they are more engaged when classroom material directly relates to some aspect of their lives. In addition, other researchers have found that when students are provided with 
material that they cannot connect with, this lack of connection has an impact on the ways in which they see their identity in relation to classroom learning, such as their perceived identity as a reader (Compton-Lilly, 2006; Skerrett, 2012). Therefore, teachers must be explicit about the text choices that are provided to students if the intention is to engage them in dialogic discussion, and more particularly if teachers are asking students to take a critical stance in response to the text (Thein, Guise, \& Sloan, 2015).

Further consideration of taking a critical stance during discussion includes realworld texts at the center of conversation. When students are given the opportunity to engage in talk about critical events that are shaping their lives, they may engage in discussion to build understandings with one another while shaping their conversation and disagreement around politically motivated topics (Hendrix-Soto, 2016). Malloy, Rogers and Cridland-Hughes (2015) explored the possibilities of using real-world texts and argumentation structure to encourage students' participation in classroom discussion. They found that when students were given authentic topics that they could personally connect to, they were more apt to take on leadership roles in organizing and enacting discussion. Further, students encouraged taking up of others' perspectives and disagreement within discussion. In the beginning, students were shouting out their responses on controversial topics, yet as they progressed through research and exploration of their viewpoints, students' perspectives were challenged. Further, students began to take up the intricacies of such topics during discussion as they engaged in perspective taking and found voice on topics that were meaningful to them.

While it is important to understand how students might engage in taking up critical stances during classroom discussion, attention must also be given to the ways in 
which teachers facilitate these critical stances in the classroom. Bickmore and Parker (2014) conducted a multiple case study that observed how teachers develop constructive conflict talk in their classes. During the study, one teacher engaged students in conflict talk by giving them global roles as citizens of a community and gave each contentious issues to research. This complex simulation required students to present an argument while their peers took opposing perspectives, not unlike the work of Mallow, Rogers, and Cridland Hughes (2015). However, students were not given the opportunity to refute arguments, which negated the possibility for perspective taking, and were under the impression that winning the argument was the most important part of the discussion. While this simulation required disagreement, a later town hall process, in which students met in small groups in their citizen roles to discuss issues, provided a space for potential disagreement as students were expected to develop cooperative dialogue based on multiple group perspectives. However, groups were required to reach a uniform consensus and were not briefed on discussion norms, therefore disagreement often ensued as students vied to win each other over with their points. Overall, teacher pedagogy in this space did not focus on the ways in which conflicting talk can encourage perspective taking to promote shared understandings, but rather on zero-sum debate in which one decision was made.

Conversely, in another classroom within the study, a teacher chose to enact a unit around racialized bullying through the use of a multicultural text. This teacher took up a variety of talk tools to guide students into conversing about the text, and the controversial subject matter, including role-play, simulations, and the introduction of whole class discussions. However, she found that after some reading, students were taking a negative 
viewpoint in response to the victim in the story. The teacher then took up drama as a means of encouraging students to reconsider their stance in relation to the main character, opening up whole class discussion to build on each other's perspectives and eventually come to a shared consensus. Overall, the researchers found that dialogic conflict talk is difficult to implement in the classroom, finding that none of the teachers were successful in sustaining student discussion even though some teachers did introduce conflict talk with norms for discussion, and engaged students in the recognition and perspective building of divergent views.

The studies above highlight the myriad ways that critical stances can be adopted during discussion, including responding to literature, talking about real-world texts, and engaging in argument. Some of these studies also problematize the nature of taking up critical stances in that they may not transform discussion when students continue to ascribe to known cultural models, shy away from disagreement, or cannot relate to the material at hand. Further, the taking up of critical stances during discussion can also be problematized by teachers as they may not promote perspective taking, set up norms for talk in their classrooms, or engage students in a deeper understanding of what disagreement during discussion might look like. The next section discusses, in more depth, how perspective taking may or may not occur during classroom discussion.

\section{Perspective Taking}

As some of the studies above purport, adopting critical stances during classroom discussion can be problematized by the ways in which students and teachers engage in perspective taking. Research has shed further light on the complicated nature of moving toward dialogic discussion in the classroom in which teachers encourage perspective 
taking (Chisholm \& Shelton, 2016). When observing two teachers, Zhang, Niu, Munawar, and Anderson (2016) found that one teacher more quickly relinquished control as a leader and facilitator of discussion, using scaffolded talk moves that encouraged student participation, sharing of multiple perspectives, and consistent reflection. The second teacher, on the other hand, had more difficulty relinquishing control and kept authority over topics and turn taking, continuing to provide evaluative responses to students' statements and less open-ended questions. While teachers' goals may be that their use of talk in the classroom is to provide students with the space to participate in authentic, critical, student-centered discussion, the enactment of such goals may not always align. Teachers' goals may become problematized when students' perspectives do not align with those goals, or when they have preconceived "right answers" for students to discuss rather than encouraging the development of new perspectives through uptake (Dong, 2008). In order to provide students with the opportunity to ask questions, build on each other's ideas, and provide real-world connections in order to better understand a text, teachers must adopt a number of different roles during discussion, even shifting from his or her own agenda in order to take a genuine interest in students' perspectives and encourage students to do the same with their peers. While co-construction of difficult talk does not come without its challenges and takes time to develop in the classroom, as students became more adept at participating in discussion with the support of teacher modeling, they will be better able to consider multiple perspectives through the presentation of different arguments or viewpoints and learn to build on one another's disagreements to come to shared understandings around a text or topic (Boyd \& Markarian, 2015). Further, students may able to more authentically attend to discussion 
on critical topics and formulate their own views on issues rather than accept others' perspectives as the status quo (Carbone, 2011).

Teachers must take into consideration the ways in which they can encourage students to take on interpretive authority by imagining and reimagining the many perspectives that a text can encourage. When students are given the opportunity to consider both the text and their own interpretations of the world, they may engage in dialogic discussion as they posit multiple perspectives and in turn challenge their own understandings, resulting in tensioned talk that drives the development of new ideas (Chisholm \& Loretto, 2016). Sherry's (2014) study takes into consideration the points made above as he examined the ways in which students engaged in, and developed, disagreement during whole class discussion in a high school English class. He juxtaposes the talk in this classroom as students engaged in both non-collaborative disagreement and collaborative disagreement. During non-collaborative disagreement, students did not take up others' views or engage in any perspective taking, whereby discussion was enacted with students talking past one another to prove their points to their peers. However, during collaborative disagreement the teacher purposely took up different talk moves. Rather than responding with the traditional I-R-E evaluative moves she took up "indirect challenges" and "provocative paraphrases" (p. 152), where she challenged students through the use of third person and paraphrased students' assertions by juxtaposing their statements against opposing viewpoints. These talk moves, the author noted, are characteristic of The Dozens, an African American cultural disagreement practice. As the teacher engaged students in these talk moves, Sherry found that students then began to take up the strategies themselves, engaging one another in increasingly collaborative 
disagreement. Ultimately, Sherry posited a number of assertions, including that collaborative disagreement amongst students can exist; teachers can promote collaborative disagreement through the use of cultural practices such as The Dozens, which engages students in conflict talk; and finally, that collaborative disagreement promotes argumentative discourse in the classroom.

Many of the studies above point out the complicated nature of engaging students in perspective taking in the classroom; this can become further complicated when taking into consideration the ways in which identities shape discussion. Students often feel pressured to perform multiple identities as they seek out competing views of themselves, resulting in a heavy emphasis on peer status in regard to who gets speaking rights within a space. While students may be given the option to participate in talk that connects their personal and cultural worlds to their school worlds, such as in Sherry's (2014) study above, the ways in which talk is valued within that space may dictate how students participate in discussion. Gritter (2012) observed two students in separate, tracked classrooms and found that both were able to perform knowledgeable identities through discussion, sharing deeply personal information about themselves as they also became "experts" in content. However, in the lower tracked classroom, students getting the "right" answer was more valued, while in the slightly higher tracked classroom, students were given the opportunity to question and push back against texts. Further, in the higher tracked classroom, multiple perspectives were valued when students shared ideas during discussion. It is of equal importance to consider the ways in which space and the inhabitants within it might shape students' participation structures, in addition to how teachers promote perspective taking talk. 
As students and teachers participate in classroom discussions, the ways in which perspective taking does or does not develop may shape the dialogic nature of talk. These studies examined the complicated nature of perspective taking, noting that it does take time to develop in a classroom, and show how students engaged in both uncollaborative and collaborative disagreement with one another. Further, they examined the ways in which teachers' talk moves and modeling of discussion may promote or hinder perspective taking. The next section attends to other factors that may shape discussion, including power, agency, and voice.

\section{Power, Agency, \& Voice}

Power. The function of power in discussion is often not separate from how participants position one another in response to each other and the texts before them. Clarke's (2006) longitudinal study of literature circle discussions which followed students through fourth and fifth grade highlighted the ways in which girls in one classroom engaged in positioning boys within their discussions, thereby acquiring power in their literacy practices of "doing school". However, he also noted that the boys gained power in the classroom by rejecting the identities thrust upon them in response to the girls' attempt to position them as non-learners in the classroom, and instead taking up power by physically altercating with one another, a practice that was not school sanctioned. It is important to note that both students and teachers are positioned within discussions by the political and ethical nature of literature discussions. However, in regard to power, students often adopt their teacher's position in response to literature in a non-passive way, taking up their teacher's statements and further elaborating on their own positioning by the text (Wortham, 2001). In addition to a teacher's positioning, 
students may also position themselves as they seek to obtain power during discussions. One example of such positioning during literature discussion is the positioning of each another, and the positioning of self in relation to social class identity performances, which may perpetuate critical conversations around stereotyping or labeling (Thein, Guise, \& Sloan, 2012).

Agency \& Voice. When power is unevenly distributed amongst students and the discourses projected in their classrooms, students' agentic participation in discussion, as well as their voice, may be silenced. In Hinchman and Young's (2001) yearlong study of one classroom, two students seemed to lose their voice and speaking rights as the year progressed. Both students began the year by readily participating in small group discussions surrounding literature; they also noted that participation was one aspect that made for "good" discussion. However, as the year progressed, each student began to grow more silent and eventually did not participate by speaking at all. This steady decline of participation may have been based on their constructions of race, gender, and class, which were markedly different from their classmates' views. When students wish to voice an understanding that goes against the status quo, it can problematize their participation (Hall 2016). This may especially occur when conversation focuses on dominant societal discourses, such as the social mobility obtained with literacy practices, students may be hesitant to voice a response or feel they must reinforce the dominant discourses at play (Rogers, 2002). These moves may also be characteristic of students' grappling with perspective taking during discussion.

Conversely, providing students spaces to agentically criticize texts and the world around them may cause them to redefine teacher-student roles, and peer to peer roles, in 
discussion through the use of questioning and uptake (Rogers, 2002). Students may believe their participation is one form of agency they have in the classroom, choosing to participate or not participate, as was the case of Glenn and Ginsburg's (2016) work. In order to better understand how students gained agency and understandings of self, they spent time in a traditional English classroom and a Young Adult Literature classroom. They found that students identified their participation in the traditional English class as a game to play in which there were right and wrong ways to participate. However, in the young adult literature class, as students were given more opportunities to gain agency in the classroom space through choice and voice, they seemed to (re)construct their identities in the process. This identities reconstruction is further complicated by the continual negotiation of performed identities in the classroom. When students gain more agency in the classroom, they may also begin to gain voice. As other students begin to see them as valuable participants in discussion, building upon their ideas, these normally silenced students may begin to see the value in their contributions (Nachowitz, 2015). Further, this may encourage a more diverse acceptance and uptake of ideas, allowing students to engage in perspective taking in the process. Yet, this can cause others to silence them, interrupt them, or devalue their contributions as they continue to perform identities they had characteristically embodied within this space, rejecting others' new performed identities in the process (Hall, 2011). This may cause the emergence of disruptive talk as students who typically stay quiet find voice during classroom discourse, causing those that normally perform leader identities within discussion to have to share that space. 


\section{The Shaping of Teacher Agency and Voice}

Just as students are provided with (or prevented from) opportunities to gain voice and agency in the classroom, so too are teachers based on various influences. These influences, and the subsequent opportunities or denials of agency and voice, may affect the ways in which they make pedagogical choices in their classrooms. One primary example are policy changes, which may hamper what teachers are able and unable to do in their classroom space. In a three-year longitudinal study, Sloan (2006) followed three teachers as they navigated changes in their accountability curriculum policies. While these teachers may have felt their classroom practices were hampered in the process, they reacted in different ways. One teacher took up agency by going to her administration and fighting to keep some of her teaching practices in place, namely that students were able to engage in dialogic discussion practices in her classroom. These teachers' identities and agentic moments often correlate with the figured world which these teachers inhabited: this teacher in particular expertly moved within the educational climate in order to promote that which was of import in her classroom. This research suggests that teachers are not predictable in responding to the educational landscapes within which they reside, nor should their identities and the figured worlds with which they inhabit be discounted as sites of understanding.

In a similar strand, Newell, Tallman, and Letcher (2009) studied how one Further, teacher's professional identities are often developed over time, and shaped specifically by ways in which they gain agency in the classroom. For example, in a study that followed a teacher throughout the beginning of her career, researchers found negotiating between the demands of the department, while meeting the administrative demands of the school 
caused this teacher to begin to shape her identity as an English teacher (Newell, Tallman, \& Letcher, 2015). However, this teacher did not feel agentic in meeting these various demands. As she continued in the profession, she began to develop more agency, making curriculum choices on her own, and developing her pedagogical identity in her classroom as separate from her colleagues and her teaching program. In addition, she also began to view her students as capable readers and writers, and was solely responsible for creating and enacting an AP program at her school. This research speaks to the notion that identities are both constantly shifting and performed in response to others.

Fecho, Graham, and Hudson-Ross (2005) coin a term that may be most apt in considering how teachers enact agency within their classroom: "the wobble". They characterize the wobble as moments when there is a disruption or shift between figured worlds as teachers negotiate the tensions between them. Within their study, teachers were given the opportunity to engage in discussion with one another to work through the dialogic tensions of their figured worlds. Further, teachers were given the opportunity to visit discussion participants' classrooms in which pedagogy was markedly different from their own. Notably, the process of discussing teaching tensions was transformative for some teachers. As a result, one teacher in particular allowed her students to do something they had never done before: critically discuss the stereotypes and racism that were present in their reading, a prime example of "the wobble" the authors discuss as this teacher worked through her own pedagogical tensions in the process. However, for some teachers, undergoing this work destabilized their figured worlds, leaving them feeling unsure about their place within them. 
The studies above capitalize on the notion that power, agency, and voice can be shaped by a number of different factors, including the topic of discussion, the ways in which participants enact discussion, and the ways in which students and teachers are positioned by others around them. While this literature review is divided into sections, I do not see the themes represented above as working devoid of one another. Critical stances, perspective taking, and power, agency, and voice are not stand-alone concepts. Rather, they are all discursively at play during discussions and shaped by performed identities, which are in turn shaped by the myriad experiences of one's life.

\section{Extensions}

This study seeks to extend the above research by exploring the ways in which identity performances shape classroom discussion across three contexts (whole class discussion, literature circle discussion, and political circle discussion. As Galda and Beach (2001) argued, a sociocultural perspective on discussion must take into account the ways in which social contexts shape the nature of discussion. Researchers are now considering how social practices, identities, and interactions are shaping the ways in which readers are responding to texts. However, dialogic discussion centered on literary texts and real-world texts is still developing in the classroom, which belies a need for my research on both how and why this type of talk does or does not develop, as well as how identity performances shape this discussion and, in turn, allow for critical talk, perspective taking, and the development of power, agency, and voice. Lewis et al. (2007) argued, "Learning shapes subject formation, which shapes identity enactments that allow for different types of agency...but the power of that agency still depends on recognitions...which draw heavily from the discourse community 
the person is trying to enter" (p. 20). Of particular interest in this study is a consideration of students' identity performances as they shape discussion in relation to: a) how critical (political) talk and disagreement develops over time within the classroom b) how students consider (or don't consider) multiple perspectives c) how students gain (or lose) voice and agency.

\section{Conclusion}

In the next chapter, I provide the methodological rationale for choosing an ethnographic approach in this study. I also describe the site and participants of this study, my research questions, and the methods of data collection. Finally, I describe the methods of analysis taken up to explore the following research questions:

1) How do identity performances shape the ways in which students and their teacher participate in classroom discussions?

2) How do these identity performances mediate the development of critical talk during classroom discussions? 


\section{CHAPTER 3}

\section{METHODOLOGICAL RATIONALE}

I situate this qualitative research study at the intersection of ethnographic and discourse analytic approaches for both collecting and analyzing data. Adopting an ethnographic methodological approach affords me the opportunity to deeply immerse myself in the culture of this classroom in order to gain a greater understanding of the practices and lives of the people within it (LeCompte \& Schensul, 2010, Sunstein \& Chiseri-Strater, 2012). In other words, an ethnographic lens studies the "locally specific" context in which people's behavior can provide a better understanding of the meaning making and construction of their worlds (LeCompte \& Schensul). By spending time in this classroom studying the everyday rituals of the teacher and his students, I hope to gain a better understanding of how identity performances shape whole class discussion, literature discussions, and political discussions. Lewis (2001) qualifies the importance of this type of work in classroom research by citing the following:

Quantz (1999) argued that educational researchers would do well to examine the daily rituals that establish cultural meaning in school $-\mathrm{a}$ teacher's lecture, for example, or classroom patterns of interaction. School ethnographers should examine how students and researchers "perform 
their identities and their politics" (p. 509) in the seemingly mundane ritualized activities that make up school life. As Qauntz pointed out, "[It is] in the smaller, daily rituals, we are likely to find the real stuff of cultural politics. It is there that we are able to see how power is skillfully applied and just as skillfully resisted" (p. 509).

By studying discourse across the contexts mentioned above, I hope to better understand how both the teacher and his students are performing their identities through the many different local discourse practices of their school lives. Further, studying whole class discussion, literature discussions, and political discussions will allow me to explore the ways in which discussion is developed in this classroom. Taken together, I will describe how these teacher and students' identity performances shape the ways in which they participate in discussion as they develop critical (political) talk/disagreement, engage in perspective taking, and gain (or lose) voice/agency in this classroom.

In choosing to take up an ethnographic approach, in which I will spend significant time in this classroom in order to immerse myself in the everyday discourses of the local site, an understanding of the complicated nature of language is addressed. More explicitly, a study of everyday language over an extended period of time allows for a more thorough exploration of how discourse becomes a mediator for power and agency in the classroom, as well as how students and teachers perform identities through discourse across daily activities. Further, this approach allows for the presentation of a picture of this classroom from the member's perspectives, an important consideration when arguing that language is situated. As Gee (2014) argued, speakers actively design their language in order to position listeners in a certain way, while listeners "give words, 
phrases, clauses, and sentences, and groups of these, specific situated meanings based on a construal of what constitutes the relevant parts of the context as the context exists in the world and as it is actively created, construed, and constructed in and through language and interaction" (p. 21). Studying the ways in which both students and teachers perform identities throughout everyday practices by taking up discourse as a mediating device allows for a deeper understanding of how those everyday rituals impact learning. An ethnographic approach allows for the exploration of critical issues that arise in these local, daily rituals that might otherwise be overlooked in research that is more abbreviated in nature, such as when and how talk occurs, as well as how unexpected critical moments (such as the presidential election) can heighten performed identities within discussion.

\section{Context and Setting}

This qualitative research study took place at Marville High School, a tracked high school located on the outskirts of a large city in the southeastern United States. Before conducting this study, I had been involved in research in this classroom on two previous occasions. The first occasion, where I was initially introduced to the teacher, occurred during the spring of 2014. I was not part of data collection for this study, but came in to perform data analysis, as well as theorize and conceptualize learning via manuscript drafting and publication. This occurred the summer before I started my doctoral studies at University of Louisville. The second occasion occurred during spring of 2015. I conducted a twelve-week pilot study in this classroom. The intent of this pilot study was twofold. First, I was interested in exploring whether this classroom might become the site of my dissertation study; I knew from working with Mr. Stark previously that his 
teaching methods were not always conventional, and for this reason I was interested in spending more time there. Second, I utilized this opportunity as my first independentlyconducted study. The purpose of the study was to observe Mr. Stark's identities and language in the classroom to provide students with avenues to connect to classroom practices and achieve growth in an educational setting. In this study, not unlike my current dissertation, I focused on the following research questions: a) How does one teacher's identity shape students' attitudes toward literacy learning in two different classroom environments, and b) How does teacher language promote or hinder students' participation. These questions were developed in consideration of the broad constructs that I was interested in possibly exploring for my dissertation.

\section{Description of Marville High School}

Marville High School is a Title I school that within the last year went from a classification of "Needs Improvement" to "Proficient/Progressing". These classifications are based on the state standardized performance test scores of students. Marville's movement out of the "Needs Improvement" category also moved them out of the status of "Priority School" (a school that is given more assistance and a focused approach for future achievement) within the district. Marville has a diverse student population with 61.3\% White, 20.7\% African American, 12.9\% Hispanic, 2.8\% Asian, and 2.3\% classified as Native American, Pacific Islander, or bi/multi-racial. 77.7\% of students are entitled to free or reduced lunch. There are approximately 1200 students enrolled at the school.

The local site for this study was one $10^{\text {th }}$ grade Honors English classroom. I selected this site because a) I wanted to learn more about this school and its student 
population, particularly because this school requires career tracks for its students b) I had worked previously with the teacher and his $10^{\text {th }}$ grade Honors English students, and c) I found the teacher's talk, as well as his interactions with students, intriguing, particularly in the ways in which he discussed himself as a teacher. Upon entering Marville High School, students choose or are placed into the following career tracks: International Studies/Cambridge (an opportunity for students to earn an international diploma and college credit), Education, Human Services (Law, Fire, Police, \& EMT), or Heavy Equipment Science (see Table 1).

\begin{tabular}{|c|l|c|}
\hline Career Track & \multicolumn{1}{|c|}{ Description } & Example of \\
& Course(s) \\
\hline & $\begin{array}{l}\text { Students in this track are given the } \\
\text { opportunity to take courses through the } \\
\text { Cambridge International Examination } \\
\text { Program (through Cambridge University, } \\
\text { London) which provides them with the } \\
\text { possibility of an international diploma } \\
\text { and college credit. This track is } \\
\text { Studies/ } \\
\text { Cambridge } \\
\text { considered rigorous, and the school } \\
\text { recommends this track only for students } \\
\text { that have an established, strong academic } \\
\text { record. }\end{array}$ & $\begin{array}{c}\text { Advance Placement } \\
\text { English, Global } \\
\text { Studies }\end{array}$ \\
\hline Education & $\begin{array}{l}\text { Students in this track are given the } \\
\text { opportunity to work with elementary } \\
\text { and middle school students while } \\
\text { learning the foundations of teaching } \\
\text { This track provides students with } \\
\text { information about higher education } \\
\text { institutions where they can continue } \\
\text { their education career path. }\end{array}$ & $\begin{array}{c}\text { Principles of Learning } \\
\text { \& Teaching }\end{array}$ \\
\hline Human Services & $\begin{array}{l}\text { Students in this track are given the } \\
\text { opportunity to train in firefighting, } \\
\text { police, and emergency medical services. } \\
\text { This track helps prepare students for } \\
\text { federal public service positions. }\end{array}$ & $\begin{array}{c}\text { Emergency Medical } \\
\text { Services Training }\end{array}$ \\
\hline EMT) & & \\
\hline
\end{tabular}




\begin{tabular}{|c|c|c|}
\hline $\begin{array}{c}\text { Heavy Equipment } \\
\text { Science }\end{array}$ & $\begin{array}{l}\text { Students in this track are given the } \\
\text { opportunity to train in the operation of } \\
\text { heavy equipment, such as bulldozers or } \\
\text { excavators. This track also helps } \\
\text { students obtain a Commercial Driver's } \\
\text { License, as well as learn about } \\
\text { equipment maintenance/repair. This } \\
\text { track prepares students for an entry- } \\
\text { level position working construction or } \\
\text { heavy equipment operation. }\end{array}$ & CDL Licensure \\
\hline
\end{tabular}

Table 1: Marville High School Career Track Descriptions

Based on their chosen or obligatory track, students have a defined course load over the next four years, which usually, though not always, dictates their placement into core courses as well. Students are also placed into core courses based on their $8^{\text {th }}$ grade standardized test scores. English classes at Marville occur on three levels:

Comprehensive, Honors, and Advanced Placement. Honors students are considered to be in the "middle level" English class, although it's worth noting that the teacher shared with me through casual conversation that he believes behavior also dictates students' placement as well. Students do have the opportunity to switch tracks through the end of their sophomore year. After this, they must stay in their current track for the remainder of the time. Students can be considered Cambridge/AP in their core courses while simultaneously participating in, for example, the Law Enforcement track. Students have the option to choose to bump down in their core courses at any time. If students want to bump up (i.e. go from Comprehensive to Honors), they must have certain test scores to do so-if they have exhibited what is considered by teachers or the school to be disruptive or negative behavior in their previous classroom, they are usually not given this opportunity regardless of their test scores. 


\section{Participants}

The participants of this study include the teacher, over the course of one school year, and his 28 Honors English students during the fall of the 2016-2017 school year. Each student who chose to participate in this study was given a consent form that was signed by his or her parent/guardian and an assent form that he or she signed. Data collected involving students who chose not to participate were not used in the reporting of results. All participants have either chosen or been given pseudonyms.

The teacher shared with me in casual conversation that he considers Honors students to be "higher achieving" students due to their placement in this course based on test scores (as compared to being placed in the comprehensive English class), as well as his own observations in comparison to his comprehensive classes. Nearly all of the students have shared with me in casual conversation the occupations and educations of their parents; based on this, most students in this classroom would be considered to come from a working-class background. Because of the district wide bussing system, students come from many surrounding areas of the city, and therefore do not all live in the community in which Marville is located. Below, I identify the focal students for this study, which are discussed more thoroughly in later chapters (see Table 2).

\begin{tabular}{|c|c|c|c|c|}
\hline Student & $\begin{array}{c}\text { Age, } \\
\text { Gender }\end{array}$ & Race & Career Track & $\begin{array}{c}\text { Future Plans } \\
\text { After Graduating }\end{array}$ \\
\hline Katherine & 16, Female & White & Law Enforcement & Air Force \\
\hline Emily & 15, Female & White & Law Enforcement & College-Nursing \\
\hline Taylor & 15, Female & White & Law Enforcement & College-Nursing \\
\hline Jorge & 15, Male & Latino & Law Enforcement & $\begin{array}{c}\text { College- } \\
\text { Engineering }\end{array}$ \\
\hline
\end{tabular}




\begin{tabular}{|c|c|c|c|c|}
\hline Kassie & 15, Female & $\begin{array}{c}\text { African } \\
\text { American }\end{array}$ & $\begin{array}{c}\text { Cambridge/Internatio } \\
\text { nal Studies }\end{array}$ & $\begin{array}{c}\text { College- } \\
\text { English/Social } \\
\text { Work/Medicine }\end{array}$ \\
\hline Ethan & 15, Male & White & Law Enforcement & College-Pre-Med \\
\hline
\end{tabular}

Table 2: Focal Students

The teacher, Mr. Stark, is a White man in his mid 20’s. Mr. Stark has four years of teaching experience and received tenure at the beginning of the 2016 school year. $\mathrm{Mr}$. Stark also completed his M.A. degree in English this year. He was selected for this study based on my previous experiences conducting research in his classroom, as well as initial data analysis of a 90-minute initial interview; this analysis (see Chapter 4) led to the development of my research questions as well as the exploration of figured worlds (Holland et. al., 2001) as a component of my theoretical framework. Mr. Stark teaches four $10^{\text {th }}$ grade sections of Comprehensive English and one $10^{\text {th }}$ grade section of Honors English. He is also the $10^{\text {th }}$ grade faculty advisory representative. This year, Mr. Stark became an academic team coach for Marville High School. This position was something that he was asked to do and, while he speaks about it somewhat reluctantly, each time I was there when it was a competition day he showed excitement about the opportunity to "crush" another school.

Other participants in the study include faculty, staff, and administration working within Marville High School. Interactions with these participants mostly occurred through casual conversation in order to gain contextual information about the school, including how students are placed into career tracks (and what those entail) and the daily rituals that occur in and around the school. 


\section{Research Questions}

The purpose of this qualitative study is to analyze and theorize the relationship between discourse and identity performances within Mr. Stark's English language arts (ELA) classroom. I seek to extend the body of research that theorizes identity and discourse (Gee, 2014; Holland et al., 2003; Lewis et al., 2007) by exploring how identity performances shape discussion within this classroom. Specifically, I study the ways in which students perform identities across discourse practices (whole class discussion, literature discussion, political discussion) and how those performances shape the ways in which they develop political talk/disagreement, engage in perspective taking, and gain voice/agency. While the literature speaks much of the broad implications of experiences and the ways in which they shape identity, I seek to understand how this teacher's "language-in-use" (Gee, 2014; Rymes, 2016) allows him to perform identities within his classroom that in turn inform his daily, localized instructional practices, and his discussion practices with students. Methods and analysis will focus on the dialectical relationship between classroom discourse and identity performances across discussion contexts. The study addresses the following questions:

1) How do identity performances shape the ways in which students and their teacher participate in discussion?

2) How do these identity performances mediate disagreement and perspective taking during classroom discussions? 


\section{Data Collection}

I adopt an ethnographic approach towards data collection, focusing on the local, everyday experiences of participants. In this way, I approach data collection with a belief that the data is "defined by and framed within the set of cultural practices and meanings specific to a given community" (LeCompte \& Schensul, 2010, p. 145). Further, these data were collected in consideration of how to answer the research questions listed above (see Table 3).

\section{Observations}

I began my observations for this study in the spring of 2016 and continued through fall of 2016 (student data collected from the fall only is included in this study). Consent and assent forms were distributed in both the spring and fall semesters of 2016

due to a change in student population. I arranged with Mr. Stark that I would not hand out assent forms until students had completed consent forms in order to minimize confusion. I talked to the students about the study and allowed them to ask any questions they had. Students' main questions revolved around my role at University of Louisville and what I wanted to do in the future.

During each of my observations, I would arrive at the school and buzz the front office. Once in the building, I would go to a computer to sign in, entering in my name, where I was visiting, and my reason for visiting. Oddly enough, the dropdown menu for where I was visiting did not include a classroom, so I would always mark "Other" in this box. The irony of this situation did not escape me as this seemed to denote my marker of researcher within the school. The computer would print out a bright yellow name tag that I stuck to my shirt. At the beginning, I rarely made contact with the two women who 
worked in the office, other than the one who buzzed me into the door and an occasional hello. The computer negated this interaction. However, as time went on, I began to exchange casual conversation with them-they also began to expect my presence and would buzz me in before I finished stating my purpose. I would then climb the stairs to the second floor and proceed down the hall to room 222. This walk almost always occurred in between classes, so the hallways were usually crowded with students clumped up in groups talking or ambling along to class. Once I arrived at Mr. Stark's classroom, I would find a place to sit. This varied from observation to observation. During my observations, I sat near the door in a rolling office chair, behind one of Mr. Stark's desks on a stool, and near or at tables of students. I used a journal to write field notes, in the form of "jottings" (Emerson, Fretz, \& Shaw, 2011), on my visits, and I digitally recorded my classroom observations. I set up an iPad on a tripod in one corner of the room, or in a more central location during the circle discussions, which allowed for a vantage point that captured more participants during this context. A description of literature discussions occurs more fully in chapter 6. After my 65-minute observations, I usually stayed after to chat with Mr. Stark. These conversations lasted anywhere from 1540 minutes, and were either formal or informal. If formal, I would ask Mr. Stark's permission to audio record the conversation. Finally, I would go back to the office to sign out on the computer; at this point, school was out but many students were usually still milling about around both the inside and outside of the building.

In addition to field notes and digitally recorded classroom observations, I also completed 5 audio recorded interviews with the teacher and 2 audio recorded interviews with the focal students, 1 of which occurred individually and one of which occurred 
during table group work. These interviews lasted anywhere from 15-45 minutes. Students were chosen based on their interactions within the classroom during my observations as well as their participation in the circle discussions. These interviews were audio recorded. They consisted of questions about Mr. Stark's teaching style as well as questions related to classroom occurrences (see Appendix A and Appendix B).

A secondary data source was compiled of artifacts that I collected throughout my observations. These artifacts included photos, student writing, Mr. Stark's website and Twitter account.

\begin{tabular}{|c|c|c|c|}
\hline Data & Method of Collection & Method of Analysis & $\begin{array}{c}\text { Research } \\
\text { Question } \\
\text { Considered (see } \\
\text { questions } \\
\text { above) }\end{array}$ \\
\hline Fieldnotes & $\begin{array}{c}\text { Written daily in } \\
\text { notebook in the form } \\
\text { of "jottings" } \\
\text { (Emerson, Fretz, \& } \\
\text { Shaw, 2011), later } \\
\text { turned into longer } \\
\text { notes/memos }\end{array}$ & $\begin{array}{c}\text { Jottings/Expanded } \\
\text { Fieldnotes/Memos (see } \\
\text { Table 4) }\end{array}$ & $1 \& 2$ \\
\hline $\begin{array}{l}\text { Interviews (see } \\
\text { Appendix A and } \\
\text { Appendix B for } \\
\text { protocols) }\end{array}$ & $\begin{array}{l}\text { Conducted both } \\
\text { formally and } \\
\text { informally; if formal, } \\
\text { participant was asked } \\
\text { for permission to } \\
\text { voice record (on } \\
\text { Smartphone and } \\
\text { digital recorder) }\end{array}$ & $\begin{array}{l}\text { Grounded Theory } \\
\text { Approach, incident- } \\
\text { with-incident coding } \\
\text { (Charmaz, 2014) to } \\
\text { develop codes }\end{array}$ & $1 \& 2$ \\
\hline $\begin{array}{l}\text { Video and Audio } \\
\text { Recordings of } \\
\text { Observations, which } \\
\text { included Literature } \\
\text { Circle Discussions } \\
\text { and Political Circle } \\
\text { Discussions }\end{array}$ & iPad on tripod & $\begin{array}{c}\text { Literature circle } \\
\text { discussions/political } \\
\text { circle discussions } \\
\text { transcribed using } \\
\text { conventions denoted in } \\
\text { Table } 5 \text {; sections of } \\
\text { whole class } \\
\text { observations } \\
\text { transcribed in } \\
\text { triangulation with }\end{array}$ & $1 \& 2$ \\
\hline
\end{tabular}




\begin{tabular}{|c|c|c|c|}
\hline & & $\begin{array}{l}\text { memos from field } \\
\text { notes; both coded to } \\
\text { triangulate with field } \\
\text { notes }\end{array}$ & \\
\hline $\begin{array}{c}\text { Mr. Stark's } \\
\text { website/Twitter } \\
\text { account }\end{array}$ & $\begin{array}{c}\text { Open access on the } \\
\text { Internet/Twitter } \\
\text { handle shared with } \\
\text { me }\end{array}$ & $\begin{array}{l}\text { Website used as a } \\
\text { secondary source to } \\
\text { gain contextual } \\
\text { information about the } \\
\text { classroom }\end{array}$ & $1 \& 2$ \\
\hline
\end{tabular}

Table 3: Data Sources

\section{Analysis}

Considered both a theory and a method, discourse analysis is "the study of language-in-use" (Gee, 2014, p. 8). As discussion is shaped by the nature of talk, adopting an approach that theoretically describes the discourse, as well as an approach that provides a method to analyzing the discourse, fits nicely within the constructs of this research. Rymes (2016) and Gee argue that all classroom discourse analysis is critical because it is "look at language-in-use in a classroom context (with the understanding that this context is influenced also by multiple social contexts beyond and within the classroom) to understand how context and talk are influencing each other...for the purpose of improving future classroom interactions and positively affecting social outcomes in contexts beyond the classroom" (p. 8). Gee (2014) echoes this understanding of a "critical" approach to discourse analysis, and argued that all discourse analysis should be considered critical because language is political. Further, Gee (2014) argues that discourse analysis can give access to participants' figured worlds, or cultural models, which allows for exploration of what count as central, typical cases, and what count as marginal, non-typical cases (p. 97).

Discourse analysis, within the larger constructs of ethnographic fieldwork, is an excellent tool for conducting an in-depth study concerning the culture of classrooms. 
Discourse is an embedded component of classroom learning; a study of language, and the social constructs in which it occurs, marries ethnographic and discourse analytic work. Further, discourse analysis allows for a deeper exploration of talk by providing tools to analyze the ways in which discourse and context (both classroom and beyond) inform one another (Rymes, 2016). Rymes (2010) defines communicative repertoire as "the collection of ways individuals use language and other means of communication (gestures, dress, posture, accessories) to function effectively in the multiple communities in which they participate (cited in Rymes, 2016, p. 9). Exploring the ways in which students take up the "communicative resources" (Rymes, 2016, p. 10) available to them within a classroom during any given moment allows for an understanding of the diverse ways in which both students and teachers use discourse to learn and immerse themselves in classroom culture.

\section{Transcription \& Coding of Interviews}

I originally transcribed audio recorded interviews in traditional question and answer format. Transcript analysis for themes occurred through incident-by-incident open coding (Charmaz, 2014). These incidents comprised participants' responses to a number of questions. Tentative codes were constructed with the data in consideration of the research questions. Specifically, I first coded interview data to consider the performed identities that Mr. Stark and his students conveyed when talking to me (see Table 4). I coded for each utterance (utterances were bound as responses to questions or statements by me) using line-by-line coding (Glaser \& Strauss, 1967); these tentative codes were derived directly from the interviewee's utterances (i.e. "I'm me" as utterance and code). I coded interviews twice to ensure fidelity of these tentative codes that were arising from 
the data (ex. performed work ethic identity). I then compared these focused codes across discussion contexts in order to develop thematic relationships between performed identities and discussion. Through constant comparison (Glaser \& Strauss, 1967) of the focused codes across phases, clear patterns and relationships developed.

For Mr. Stark's interview data, I created a chart that set up descriptions, or moments of tension, side by side with one another (e.g., "teacher I want to be" versus "figured world of education") (see Table 4). In addition, I denoted these descriptions by line number to show where these tensions may have been spoken of separately from one another. Finally, I created a column with my own observations of the teacher's descriptions, which allowed me to further observe the teacher's language for descriptions of his understanding of "teacher I want to be" versus his understanding of "figured world of education". To sum, this layout afforded me the opportunity to analyze how these two descriptions were in tension with one another in language and meaning.

\begin{tabular}{|c|c|c|c|}
\hline $\begin{array}{l}\text { Line } \\
\#\end{array}$ & $\begin{array}{l}\text { Discourse of Teacher } \\
\text { Identity }\end{array}$ & $\begin{array}{l}\text { Figured World of } \\
\text { Education }\end{array}$ & Observations \\
\hline 101 & I'm me. & not traditional at all & $\begin{array}{l}\text { considers self untraditional, not } \\
\text { following "rules" and guidelines of } \\
\text { what it means to me a "teacher" }\end{array}$ \\
\hline 101 & ADHD-diagnosed & & \\
\hline 102 & (diagnosis makes me) fun & & \\
\hline $\begin{array}{r}102- \\
103 \\
\end{array}$ & $\begin{array}{l}\text { learned differently in high } \\
\text { school }\end{array}$ & $\begin{array}{l}\text { copying notes from a } \\
\text { book NOT how I } \\
\text { learned }\end{array}$ & $\begin{array}{l}\text { believes in giving kids multiple } \\
\text { ways of learning; disinterested in } \\
\text { use of textbook (aligns textbook } \\
\text { with tradition?) }\end{array}$ \\
\hline
\end{tabular}

Table 4: Mr. Stark Interview 1 Coding

During a second round of coding the data, further themes were identified within the larger themes of "Discourse of Teacher Identity" and "Figured World of Education". I then further expanded on these themes with observations in the third column of the table. These expansions became considerations within memos later in the process. Under 
"Discourse of Teacher Self", further coded sub-themes became "Who I Want to Be", "Students", and "Content". Under "Figured World of Education", further coded subthemes became "Key Players", "Data and Testing", and "Traditions". One interesting sub-theme that was identified occurred when these two seemingly separate worlds seemed to overlap within the data. When these moments occurred, they were coded under "When Worlds Collide" in two ways, "My Administration" and "Validation".

\section{Transcription and Coding of Circle Discussions}

Fifty-minute literature circle and political discussions were transcribed from video recordings. These included 3 literature discussions on Lord of the Flies (Golding, 1954), 2 literature discussions on The Hunger Games (Collins, 2012), and one political discussion concerning President Trump's recent election. Rymes (2016) argues that there are three dimensions of discourse: a) social context, or the understanding that social norms influence what is said in the classroom across different contexts for different functions, b) interactional context, or the ways in which discourse is recognized by others, and c) individual agency, or the ways in which participants have the power to understand and be understood by others as they perform identities to promote a sense of self. These three dimensions function dialectically with one another in that each informs the other as discourse is produced. I coded for these dimensions through the data by considering how identities are performed within these contexts. This argument drives the analysis as I seek to understand how identity performances shape classroom discussions as students develop political talk/disagreement, consider multiple perspectives, and gain voice/agency in the classroom. Literature discussions will be transcribed with the following conventions to analyze talk (adapted from Rymes, 2016) (see Table 5). 


\begin{tabular}{|c|c|}
\hline Symbol & Convention \\
\hline $\begin{array}{c}\text { Speaker continues utterance after } \\
\text { interruption of talk. }\end{array}$ & ALL CAPITALS \\
\hline Exaggerated Volume & Elo::ngated Si::ngle So::unds \\
\hline Elongated Single Sounds & $(($ whispering) $)$ \\
\hline Whispering, body gestures & $\uparrow$ Yes! \\
\hline Raised pitch & $\downarrow$ No. \\
\hline Lowered pitch & *This is quiet* \\
\hline Quiet voice & \\
\hline
\end{tabular}

Table 5: Literature Circle Transcript Denotations

Field Notes

Field notes were taken in the form of "jottings" (Emerson, Fretz, \& Shaw, 2011) during each observation. Jottings are comprised of words and short phrases that I then later expanded into longer field notes with a description (see Table 4). These field notes first took the form of general observations of the class. As my research questions became more focused and I began to home in on focal students, my field notes became narrower in scope. After each visit, I would subsequently expand my field notes into a full write up of the jottings, paying special attention to the description that I used for my observations (see Table 4). From these expanded notes, I then openly coded my field notes in response to my research questions while simultaneously taking into consideration themes that were identified from analyzing the interviews. This was done to triangulate data and ensure coding fidelity across data sources. Finally, I conducted memo-writing (Emerson Fretz, \& Shaw, 2011; Sunstein, Chiseri, \& Strater, 2011) to theorize codes/themes/descriptions 
that arose from my expanded writing of the jottings in the classroom. Many of these memos became part of the discussion in later chapters.

\begin{tabular}{|c|c|c|}
\hline Jotting & Expansion & Memo (Themes/Codes) \\
\hline $\begin{array}{l}\text { "Accountable } \\
\text { communities" }\end{array}$ & $\begin{array}{l}\text { Mr. Stark talks to the } \\
\text { students about how they } \\
\text { belong to what he considers } \\
\text { an "accountable } \\
\text { community" within their } \\
\text { school. This is in response } \\
\text { to the principal taking away } \\
\text { RISE. Mr. Stark tells the } \\
\text { students that it is their } \\
\text { responsibility to hold each } \\
\text { other accountable for their } \\
\text { negative actions (i.e. if } \\
\text { students are fighting then } \\
\text { other students should } \\
\text { "police" their behavior or } \\
\text { strongly encourage them } \\
\text { not to fight). }\end{array}$ & $\begin{array}{l}\text { This moment made me } \\
\text { consider the phrase "punish } \\
\text { the many for the few", } \\
\text { which was the tone that } \\
\text { students took when } \\
\text { discussing that RISE was } \\
\text { taken away. No student in } \\
\text { the class wanted to take any } \\
\text { responsibility, and instead } \\
\text { blamed it on "the } \\
\text { freshman". Mr. Stark took } \\
\text { this opportunity to capitalize } \\
\text { on the social norm of the } \\
\text { above phrase, which is a } \\
\text { common occurrence in } \\
\text { schools, and instead directed } \\
\text { students to consider how } \\
\text { they could take a stance in } \\
\text { the situation. This aligns } \\
\text { with Mr. Stark's belief that } \\
\text { one of his goals as a teacher } \\
\text { was to "prepare students for } \\
\text { the real world". However, } \\
\text { Mr. Stark's beliefs seem to } \\
\text { contradict a status quo of } \\
\text { "every man for himself". }\end{array}$ \\
\hline
\end{tabular}

Table 6: Field Notes Protocol

\section{Role of the Researcher}

I consider my own role as I take up an ethnographic perspective, particularly in the beliefs, histories, and values that I bring with me upon entering this site as a researcher. My lens is punctuated with these very entities, and therefore I must consistently consider myself in relation to the ways in which I write about participants and their stories. Cintron (1998) argues that a researcher's ethos is intricately tied to the 
ways in which she reports on the culture in which she is embedded. I agree, and consider ethos more as function rather than form, so that ethos becomes an understanding between reader and writer of time spent in one place, and the attempt to somehow capture the essence of that place. I view essence as both allowing the story to come alive through the writing while at the same time staying true to both those living in the place and the observations the writer makes.

I began my research relationship with Mr. Stark very much as an outsider examining data for which I was not present in collecting. When I met him for the first time it was to interview him about his understandings and beliefs of himself as a teacher. My first time in his classroom occurred a year before this study began, and I still considered myself an outsider - I was the "researcher in the corner" and spent little time with students other than to interview them at the end of the school year. During my second year in his classroom, Mr. Stark seemed to begin to treat me as both insider and outsider. For example, I noticed that Mr. Stark began to openly use curse words in front of me, whereas before he would apologize when these words "slipped". Another example of this occurred when Mr. Stark invited me to help him plan a unit for the class I was observing. By this point, we had developed a working relationship with one another, yet he still stated he was "nervous" about my presence in his room. During this study, I began to sit at tables with students, which they not only seemed to enjoy, but also gave them cause to engage me in conversation. Many times, students would invite me to their tables while they worked. As I began to become more familiar with the culture of this classroom and the participants, I found myself crossing over to insider in certain regards, such as carrying casual conversation about students' lives from week to week or being 
invited by Mr. Stark to co-create a unit with him. However, I still recognize that there was a power differential at play during my time in this classroom. Throughout my observations and interviews with Mr. Stark, he made it clear that he was nervous about what he did and did not say and, while there was definitely a comfort level increase in terms of sharing, he still saw me as a researcher with an agenda.

In considering my histories and the worlds I inhabit, I am distinctly aware of my outsider status at Marville High School—I consider this to be a consistent, reflexive awareness as I conduct my research at this site. I carry with me years of attending, diverse, rural schools. My teaching experiences were dichotomous-my experiences lie in both a predominately White, private school, but also in suburban community colleges, where I taught students from across ages, races and socioeconomic classes. The contrast between my own experiences and my observations at Marville was prevalent when I began my study — the high school felt, for me, quite similar to my own high school. However, I found that Marville was quite different in so many ways, including its presence in the larger urban district within which it resides, as evidenced by the career tracks and labeling that are present within the school. As I attempt to discuss the community of Marville, as well as the identity performances and discourse practices of Mr. Stark and his students, I have a keen understanding that I cannot separate my own identities and past from my researcher lens.

Overall, I still consider myself an outsider in this culture, as I believe that I am an observer in most regards rather than a participant. I never took on the role of teacher in this classroom, which I felt would have compromised the researcher role for me and blurred the lines of my researcher status. 
In the next chapter, I describe the town of Marville, and look particularly at how the school and Mr. Stark's classroom fit within the town. Further, I provide contextual profiles (Saldaña, 2015) of Mr. Stark and the focal students through an analysis of what they shared with me about who they are, who they wanted to be, and how they want others to see them. In chapter 5, these analyses will serve to look at the ways in which these identities were performed as Mr. Stark and his students participated in whole class discussion, literature circle discussion, and political circle discussion. 


\section{CHAPTER 4}

\section{CONTEXTUAL PROFILES: THE COMMUNITY OF MARVILLE, MR. STARK,}

AND THE FOCAL STUDENTS

\section{The Community of Marville}

The community of Marville is located on the fringes of an urban city in the southeastern United States. Once its own municipality, Marville became part of the larger city it now belongs to in a merger in the early 2000 's. It is now characterized as a city neighborhood, and is on the edge of the county line and the city itself. A largely White working-class community, the average per capita income of Marville residents sits in the low $\$ 20,000$ 's. Approximately $70 \%$ of the residents have a high school education or less, and many are employed in trade fields, such as construction, electrical, building maintenance, truck driving, and mechanics. Within and around the larger city, major employers include a shipping company, automobile and electronics plants, and a number of healthcare hubs. None of these employers reside in Marville, which has a population of approximately 8,000 and is, by observation, a small town.

In order to get to Marville, one must head south out of the city to an outer interstate that runs the perimeter. When driving towards Marville, it seems that one is leaving the city completely. Marville is located less than a mile off of one of the outer interstate exits. When exiting the interstate, few immediate buildings and no houses can 
be seen. However, Marville High School, which moved to its current location in 1958, is one of the first markers of Marville to be reached. Because it is now part of the city, Marville High School is situated within the metropolitan school system but feels much more like a rural school in terms of location. The city cannot be seen from the school, and the exit feels devoid of the hustle and bustle that one feels when walking downtown. On the side of the exit where the school is located, there is a second-hand store, an abandoned building, and the only other high school in the town — a specialty school for expectant mothers. Marville High School can be found on the main street that runs through the center of town, approximately one mile before reaching the town center. When driving through town, one can find the typical necessities: doctors' offices, a grocery store, a brand new fire station, and various other businesses, many of them locally owned. By driving the opposite direction down the exit, one can see a newly built Subway, gas stations, and business center.

\section{A Schematic View of Marville High School}

In the following section, I describe the infrastructures that make up Marville High School including. First, I will discuss the student assignment process, specifically looking at how bussing functions within this district. I will also attend to the ways in which the district clusters students in order to achieve diversity. Next, I will turn to a discussion of the career tracks available at Marville High school, and will include examples from the focal students of the processes that they went through in order to be on their tracks and, more importantly, in Mr. Stark's classroom. Finally, I will conclude with two student examples of the movement that occurs within the tracking system. 
Bussing in the district. Before describing the school, it's important to understand how students come to attend Marville High School. Almost 40 years ago, the district imposed busing in order to desegregate the city schools. While this program caused unrest in the city at the time of its conception, it is still a thorn in the side of the district. Most recently, news stories focusing on the negative impacts of bussing included the inordinate amount of funding spent to bus students (sometimes across the city from their homes), as well as the extreme ride times that students were spending on buses, which runs upwards of two hours for some of the longest rides. One local news station did an undercover investigation by following various bus routes, only to report back extraordinary times and bus switching midway. However, the district insists that the bussing is not only necessary but also successful in insuring that students are given the best opportunities for schools. In fact, this culminated in a 2006 Supreme Court case, where the court voted against the district's busing policy. However, the district, and countless parents, believed in the system, and therefore found a way to re-envision it.

Clusters. While students are able to apply to get into schools in the district, students are also given school assignments based on the clusters that they belong in (and parents ranking schools within those clusters). Assignments are made on a number of factors in order to achieve diversity—-meaning that there is no guarantee a student will get accepted into the choice that he or she makes. Marville High School is considered a magnet career school, and for that reason students often apply to go there on the basis of the programs that are offered (see Table 1). However, many of the students do not live in Marville and come from surrounding city neighborhoods—in fact, Kassie, one of the focal students discussed later in this chapter, comes to Marville from a city neighborhood 
that is considered part of downtown. Kassie, who recently moved to the city from another large, Midwestern city, shared that she has a twenty-five minute bus ride to get to school, which means that she has to get up almost forty minutes earlier than when attending her old school, which was located in the neighborhood in which she lived. For this reason, the demographic makeup of the town of Marville, a 98\% White community, does not reflect that of Marville High School today, whose diverse demographics were stated in chapter 3. Yet, the socioeconomic makeup of the school does seem to run parallel to the working-class community in which it sits: upwards of $70 \%$ of the students are eligible for free and reduced lunch. While I cannot speak to every student in the school, the focal students for this study all come from working-class families. Almost every focal student shared with me that they would be the first person in their family to attend/graduate college.

Career tracks. Further, the programmatics of the school also seem to echo a working-class mentality, much like that of Jean Anyon's (1997) working-class school. As noted in chapter 3, the school has different career tracks that the students can choose from. These career tracks all fall into what the school states as a service-learning category, meaning that they are career paths which students are put on to give back to their communities. Aside from the teaching and Cambridge/AP tracks, none of the other tracks have career choices that place students on a higher education path. For example, the Heavy Machinery track often provides students with a certificate to go straight into the workforce, or hours that go towards licensing they can receive at vocational school, such as backhoe operation. This is also the case for the Law Enforcement/Fire/EMS track, which prepares students to go directly into those career fields, or at the very least 
into the training that is required for them. Students take classes in the basics of each of these fields, which Taylor shared with me: "They [the classes] actually do the stuff that you're supposed to do, work out, shoot guns, watch videos on forensic stuff... we sometimes visit the EMS room, and we actually work on the dolls and stuff, so that actually helps a lot." Interestingly, while the service-learning career tracks promote the notion of students going directly into the workforce, the school itself promotes a collegeoriented mindset to its students. The slogan of the school—which is prominently displayed on various banners and certificates throughout the hallways and common areas - is to "prepare every student for post-secondary education". While vocational schools are a form of post-secondary education, other artifacts around the school make it clear that the focus of what constitutes post-secondary education for Marville are fouryear institutions. Taped to the wall above the lockers are "certificates" with the school's logo stating, "Jane Smith is On Track for College Readiness in Mathematics". These are various and include multiple students' names and various subjects. Other prominently displayed signs of academic promotion include a black and white list of all Honor Roll Recipients.

There are multiple signs around the school including a plaque next to the intercom on the outside next to the door that let visitors know Marville is a Cambridge International Examinations school. In fact, this career track, which is the least serviceoriented from a career perspective, seems to be the most touted at the school. It is incredibly difficult for students to join the Cambridge/AP track if they did not do so as freshman, mainly due to space restrictions. In fact, if students are not on this track they are relegated to taking Honors or Comprehensive level classes for the core content areas. 
Within this district, classes denoted Honors are characteristic of most districts in that they are middle of the road. The students that are in these courses are not considered remedial by the district (which would place them in Comprehensive courses) but are not Honors in the sense that they are "above" regular level courses (which is reserved as Cambridge or AP). Therefore, when it comes to core courses, students are placed into either remedial (Comprehensive) or regular (Honors), depending on their test scores and previous grades. These types of labels predominate the district, and Marville as a residing school, and are used by me only in the sense that they are school-sanctioned as "official" language.

As stated in chapter 3, students can move between these courses, but it is much harder to move into Honors from Comprehensive, just like it is almost impossible to move into Cambridge/AP courses from Honors. One notable exception to this scenario, although her case is not without confusion, is Kassie. Kassie explained the differences between her previous school and Marville in the following conversation, explaining the ways in which Honors courses are viewed quite differently within this district:

Kassie: We didn't have Cambridge. We had...our credits and everything were different. We didn't have trimesters, we had semesters. I like the semesters, so when they talk about finals here at the end of a trimester, I'm like, "Isn't that just like a midterm for you guys or something?" Ashley: What about your schedule here? How did that translate? Kassie: At first, they had me in all Honors classes and I felt like the Honors classes were really easy and I didn't know about Cambridge. Ashley: Mm-hmm (affirmative).

Kassie: Because I had one Cambridge class and that was because I was in the 
junior math.

Ashley: Yeah.

Kassie: I wasn't [in the other classes because I didn't] know about it, so people are like, "Are you part of Cambridge?" I'm like, "I don't know."

Ashley: You're like, "What's Cambridge?"

Kassie: When I realized what they told me what it was, I feel like it was too easy

so, I asked about Cambridge. She said she'll put me in it because I explained to them the reason why I didn't take AP classes as a sophomore and freshman... Ashley: Mm-hmm (affirmative).

Kassie: Because they didn't offer it.

Ashley: It's a different language, right? Yeah.

Kassie represents an exception to the typical track placement, but also the ways in which complications easily arise when placing students into career tracks. First, Kassie was placed into a career track based on the school's understanding of her previous education, but this was not at all correct, primarily due to Kassie's previous school having a completely different system in place of what constitutes an Honors class. This issue highlights Marville's understanding of Honors as well—a dichotomy exists between being on a track that promotes entering the workforce upon graduation (yet promoting the belief that every student is "being prepared" for postsecondary education), and Honors may be the course that gives students cause to suspend their understanding of the career track that they are on, especially when that career track prepares them for future paths other than college. Further, Kassie is an atypical case in that she does not have ALL Cambridge classes. While I did not ask Kassie to elaborate on what she meant by it being 
too late to get into the Cambridge English class, Mr. Stark has told me that the class follows an incredibly specific sequence that matches the test that students will take at the end of the year. Knowing this, I imagine that under the teacher's discretion she believed she would not have time to prepare Kassie fully to take the final examination, which not only hurts Kassie's chances of gaining college credit for the class (at least in this teacher's opinion), but also hurts the teacher's value of being a Cambridge teacher who has a goal of preparing students to pass an end of year standardized test. Below, I highlight two additional cases of students who have been at Marville for the entirety of their high school experience, and who are also exceptions to how career tracks operate at Marville.

When I first began spending time at Marville High School, many of the students that were in Mr. Stark's classes were on the Heavy Machinery/Law Enforcement/Fire/EMS track, were contained in classes together (which in Mr. Stark's case were his Comprehensive classes), and largely said they were going straight into the workforce upon graduating college. Mr. Stark teaches one Honors class section, which as stated in the previous chapter is the focus of this study. This class seems almost evenly split between students who are on the Principles of Teaching track and the Law Enforcement/Fire/EMS track. Of the focal students in this study, almost every one of them is on the Law Enforcement/Fire/EMS track and has plans to go to college, or into the military, directly upon graduation. While this track is created to give back to the community by preparing graduates to enter into those fields in which they would complete training and begin working, thereby replacing or joining many of their parents, the students that inhabit this track - especially those that are a focal point for this study- 
have peripheral aspirations that include going to college. None of the students plan to go directly into the workforce options that accompany this track — however, each student explained to me how they felt this track provided them with an opportunity to consider what they might be doing in the future. In the conversation with Taylor below, she explains how she came to be on the Law Enforcement/Fire/EMS track:

Ashley: Yeah. I know you've told me that you're on the Law Enforcement [Fire/EMS] track. Is that right?

Taylor: Mm-hmm.

Ashley: You've been on that since you started here?

Taylor: Uh-uh. Last year...I also was drawn to the principles of teaching program because I wanted to be a teacher at the time, but I got out of that this year because I didn't want to be a teacher anymore.

Ashley: Okay, so what do you want to be now?

Taylor: A nurse practitioner.

Ashley: What makes you want to do that?

Taylor: I really like helping people, and I just like being in the medical industry. I wanted to be an ultrasound technician, but I just said no to that.

Ashley: Does Marville have a track that's for people who want to go into the medical field?

Taylor: Uh-uh (negative).

While Taylor would have had the option of going to a neighboring high school that is a career magnet for Nursing, she chose to come to Marville for an extracurricular activity, namely cheer, and is therefore forced to choose from the career tracks it has in place. 
Taylor's aspirations to attend college and go into the nursing field are not exactly recognized by this track, yet she believes that this track situates her peripherally towards her goal.

Ashley: Is it [career track] making you feel like you're on the right path? Taylor: Mm-hmm (affirmative). Ashley: That's [EMS] really what you want to do?

Taylor: It may not be what's exactly there for me, but it's a good start. Taylor alludes here to the fact that Marville does not give her the opportunity to follow a path that directly prepares her for nursing — which it should be noted, is very much a service field - yet she finds a way to situate her future interests within the parameters that the school lays out for her. The school is denoted as a career track for public service in that it prepares students to enter into fields in which they will work to help the community. However, Taylor does not necessarily believe that this track is preparing her for her future pursuits. Below, Taylor talks about the association of courses that fall within the track. Students in this track are placed in either Honors or Comprehensive classes, as determined by their middle school grades and test scores. Taylor takes all Honors classes for her "core" contents; within the career tracks, all elective courses are dictated by the track.

Taylor: ...they still put me in Honors because of what I'm used to. I wouldn't want to be in Cambridge because that's too much. I think Honors is really good for me. Ashley: When you say, "it's too much, too much," what are you thinking there? Taylor: The Cambridge kids, they always have a lot of homework... Ashley: Okay. 
Taylor: In every class.

Ashley: A lot, a lot of work?

Taylor: Mm-hmm. If I had the opportunity to do it, I'd probably do it because it helps you with college credits. That's what its main point is, so I'd probably do it. As Taylor points out, students who are on the Cambridge/AP track are considered to be college bound. While the school has reiterated that they are preparing every student for post-secondary education, there is an obvious divide between the career tracks. Students who are on the Cambridge/AP track can earn college credit in many of their courses - a marker of the track. Additionally, the Principles of Teaching track is preparing students to become teachers, a career in which it is well known a four-year degree is required in order to enter the field. However, many students, like Taylor, are on career tracks that don't necessarily meet their aspirational goals, nor promote the future toward which they are working. Taylor vacillates between not wanting a large homework load, another perceived marker of the track, but wanting to be on the track for college purposes. Her understanding of the main purpose of this track may be an embedded belief that many students hold about the different tracks offered at Marville due to the fact that the future careers of workforce tracks not seeming to be recognized or valued by the school itself. For a school in which there are more tracks that promote a non-college outcome than those that do, there are no messages in signage or otherwise about immediately entering the workforce upon graduation. Even the promotion of entering into the military upon graduation is value-laden with the understanding that this immediate occupation provides students with the opportunity to have college paid for through their participation. The message seems to be this: we offer career tracks that promote students' ability and choice 
to go directly into the workforce upon graduation, but these careers are not necessarily valued or presumed to be as great of a contribution as students' choice to enter into college upon graduation. The leveling of core courses within these tracks, as discussed above, further complicates this.

Movement in the tracking system. Students are placed into core classes that the school feels complement their test scores and previous performance, and that in and of itself tracks students into a permanent line of academics - as mentioned before, students seldom switch from these levels and are not able to switch tracks after the beginning of their sophomore year. In fact, Mr. Stark shared with me that more often than not, if students do switch it is usually by his recommendation that they be removed from Honors and placed into Comprehensive. This happens for various reasons, but in the months I spent there alone Mr. Stark had plans to recommend that two students be removed from Honors due to not completing the work. I use the term recommendation, but Mr. Stark did imply that it was at his discretion and did not involve the approval of the administration. A third student, who began the year by frequently sleeping in class and minimally participating, seemed to have a change of direction midway through the first trimester and is no longer part of these recommendations.

However, two interesting cases, one a focal student of this study and another a Comprehensive student that Mr. Stark spoke with me about, highlight cases in which students are able to "jump" levels from Comprehensive to Honors. While I do not have statistical data that speak to how often this happens, all observations and qualitative data collected for this study indicate that it is quite rare. My insistence at highlighting these two cases is two-fold: first, these cases bring to light how these students took it upon 
themselves to move within a very limited system, albeit in different ways. Second, these moves are prime examples of the limiting nature of the tracks — even when these students switch from Comprehensive to Honors, which for all intents and purposes would be seen by many as a positive academic move, they are still stuck in the same career track in which they started, and therefore that mobility is stifled by the school and the system in which they are corralled.

Ethan, a focal student for this study whom I will further describe later in this chapter, spoke to me about how he came to be in Mr. Stark's Honors class. Ethan was vocal about this on multiple occasions, and seemed to enjoy telling me and his classmates that he used to be in Comprehensive but was "too smart" for it. In the following, I asked Ethan in an interview to tell me more about how he came to be in Mr. Stark's class.

Ethan: In comp classes, I would do everything last day. I would just ... Like that. It would be done. Honors classes was the same thing, even now. I don't know. Ashley: Is that frustrating for you?

Ethan: Yes and no. I feel like if I went to Cambridge, I would have to do more stuff and I don't know if I'd be able to get it all done like that because they expect more.

Ashley: You'd have to change your style.

Ethan: Exactly.

Earlier, Taylor spoke about Cambridge being a track in which the purpose is for students to gain college credit, a marker that is official in the sense that students have the opportunity to gain credit through completion of specific tasks in their classes (in most classes this takes the form of a standardized exam), Ethan speaks here of a more 
unofficial marker of the classes on the Cambridge/AP track: that they have greater expectations for students than Honors/Comprehensive classes do. Ethan may not be alone in his belief that the rigor for Cambridge/AP students is much more than that of Honors/Comprehensive students—however, the tracks play a role in developing these beliefs in that Honors and especially Comprehensive classes are associated with every non-college track, while Cambridge/AP classes are taken ONLY within that specific track, a college bound track. Students that are in other career tracks are not given the opportunity to take any of these classes, meaning that they are limited in the ways in which they can move into more accelerated classes. The school has developed a system where students very much must stay in their lanes.

Ethan continued by talking to me about his current views on the Cambridge track. At the very beginning of the year, Ethan had switched from Comprehensive classes to Honors classes, but was placed in a Cambridge math class. However, there was not enough space to place him in Cambridge classes across the board, and he was told therefore that he must move to an Honors math class in order to keep alignment between his core courses.

Ethan: If they offered me a spot in Cambridge again, I would probably take it. Ashley: Yeah?

Ethan: I'm not going to go to them and say, "I want to be in Cambridge," because honestly I don't. If they offered me a spot in Cambridge, I don't really....all the kids are stuck up. They're just like, "Oh, we're smarter than you." I've been in Cambridge classes. Last year I was in comp. I was taking tests. I was passing tests like this, this, this. I would take three tests in a day and 
100 on all of them. My Comp teachers were like, "You don't need to be in here." I was like, "Dang, that hurts." It was like, "No, you need to be in Cambridge or Honors." I went into Honors classes.

Ethan's path from Comprehensive to Honors courses came through validation from his teachers that he needed to level up, and so he took it upon himself to move within the system. However, his experience was unique in that he also previewed a Cambridge course only to feel as if he didn't fit the mold of what a Cambridge student should be, marking them as "stuck up" and feeling as if they are smarter than everyone else. For Ethan, these may be other markers of the track: that students are competitive, having test scores and academic demeanors that have propelled them into these classes. Ethan has stayed on the Law Enforcement track since freshman year, and was on this track when he spent a short time in the Cambridge math class. Every other student in this class would have been on the Cambridge/AP track, and therefore Ethan may have felt like an imposter amongst them, knowing that he was on a track that was relegated to taking lower level core courses. As mentioned before, students are placed on these tracks, which both constrain and define them. Even Ethan, who presents a case in which he agentically tried to move from one level of core courses to another, is still defined by his track. This occurs in a twofold fashion: he is defined by his track when he enters into a Cambridge/AP class and does not feel as if he fits, and he is defined by his track when he moves from Comprehensive to Honors, a jump in levels but not a change in tracks.

Ethan's experience shows not only the limited ways in which students are able to move around the system, but also the ways in which tracks shape and define a student's experience at this school. Ethan rejects taking on a Cambridge identity by stating that the 
students on this track think they are smarter than everyone else, but he simultaneously performs the identity of "smart student" as he speaks about his own experiences in Comprehensive classes, which he defines as too easy for him (as noted by his teachers). Ethan's situation shows the constraints that are placed on a student by the career tracks. He is not able to take Cambridge classes because of size limitations and he vacillates between wanting to be in them and not wanting to be in them. Further, he feels the need to justify his own intelligence as defined by the classes that he's in. By speaking about his Comprehensive classes from a standpoint of being too easy, and even going so far as to say he feels the same way about some of his Honors courses, he begins to shape himself as someone who feels he doesn't necessarily belong on ANY of the tracks here.

Another interesting situation comes from a student in one of Mr. Stark's Comprehensive classes. She had expressed interest to Mr. Stark in moving into Honors, and he believed that this was a good decision, so he began to "prep" her for the move in the second trimester, late in the year, by having her complete the same work that Honors students were doing (i.e. reading and responding to Hunger Games). He made clear that moving a student up like this, especially mid-year, was especially uncommon, but he felt that Honors would be more appropriate for her. He would refer to her often when talking to his Honors students, usually citing her work ethic, because she was turning in the work that they were doing (which she was doing on top of her Comprehensive work) sometimes a week before it was due. Mr. Stark would speak about her as if to set an example about work ethic to his class; at the point in which they were reading Hunger Games, some of them were not completing work, usually stating that they had read the books so many times they didn't feel they needed to. 
For Mr. Stark, this student was a blatant outlier compared to most of his students in the Comprehensive classes he taught. He would refer to her academic behavior and subsequent work ethic as if they stuck out like a sore thumb in a class where he felt lucky to get students to speak back him. This example parallels Mr. Stark's views about work ethic, which are expanded upon later in this chapter. Overall, the career tracks at Marville are quite complicated. While these are only a few students' stories, they work to highlight not only the complicated nature of career tracks at Marville, but the ways in which career tracks position students as they look towards their futures, as well as how some students reject the larger implications of those tracks.

\section{The Focal Students and Teacher}

In this next section, I provide impressions of each of the focal students and at the center of this study. These impressions are meant to provide context and base knowledge about each of the participants and are in no way complete understandings of their person or educational experience. Rather, my goal is to provide a backdrop of each person's life and being in the classroom to better appreciate the ways in which they perform identities through talk in the next chapter. Each of these students was chosen based on a number of different factors, including readily participating in class, not sleeping, engaging me or Mr. Stark in regular conversation, and participating in talk across different contexts.

\section{Emily: "Go Jump Out the Window"}

Emily is a member of the Fabulous 4, the group of girls that I routinely sat with at their table in Mr. Stark's classroom. I dubbed these girls the Fabulous 4 for a number of reasons: they were the first that invited me to sit with them in the classroom when I had previously sat in the corner of the room; they considered themselves a foursome within 
the classroom and would often take on tasks this way; and they had their own rules of discourse within the group, which I will highlight in Chapter 5. Three of the four girls are focal students within this study — the fourth did not ever speak much to me or within their group when I was present at the table and would sometimes sleep, therefore was not part of the inclusion criteria referenced above. Of the Fabulous Four, Emily was perhaps the most interested in my presence in the classroom. She was usually the one that invited me over and would often have side conversations with me when the rest of the group was talking. When I first started interacting with Emily, I noticed that she was incredibly cheerful. She seemed to always have a smile on her face, which was only highlighted by her braces, and would often laugh loudly during classroom conversations. Emily came to Marville to continue her cheerleading career, and had to apply to get in. She originally would have attended a neighboring school in the same cluster in which she lives. Emily participates in a private cheerleading league that isn't affiliated with the school, and her coach encouraged her to come to Marville, because many of the other girls from the squad attend school here.

Emily lives with her mom and dad, whom she described as "together", and her younger sister. Emily's statement of her parents' marital status did not go unnoticed; all but one of the other focal students' parents are no longer married, and some of them live in single parent households. Emily's mom is a homemaker, and her dad works for a construction company. One aspect of family that Emily frequently references is the death of her middle sister, who was a stillbirth. Her parents named the baby, and Emily talks about the baby as an additional member of the family. Emily spoke to me about this baby multiple times during my course of observations, and shared her experience of losing a 
sibling with her classmates. Emily told me that she was old enough to remember the death, and that her family still frequents the grave, taking flowers every once in a while.

Like many other students in her class, Emily's aspirations are to go to college after high school — she will be a first generation college student in her family. When I asked her about her feelings toward college, she said this:

Ashley: Is college important to you?

Emily: It is. How I feel ... I feel like, because I see my mom struggle and I see my dad struggle to try and take care of me and [my sister] both, so it's ... I don't want to have to depend on anything else. I just want to be able to go out, make my own money, and be able to support my family, like my dad does. My dad takes care of our family and I want to be the one that can "Oh yeah, you need help? I can help you". Just I can be there for my parents like they were for me while I was growing up.

Emily reveals much about herself in this statement and nods toward my later discussion of how she understands and engages in discourse in the classroom. Emily's family is on a one-person income, and her dad no doubt works very hard to financially support the family. However, Emily sees that this is still a struggle, and so college is a way for her to escape that struggle. Her aspirations to get a degree highlight a common assumption: that a college degree equals money, and that money equals success (as opposed to struggle). For Emily, this is also ensconced in an understanding that support goes beyond money. College means independence, and a belief that others can depend on her when they need something, just as she has depended upon her parents as she has grown up. She noted that this is the kind of support her dad provides for the family, despite the fact that her family 
may struggle financially. College, in this way, provides a security for Emily that she feels her parents do not have.

Because she wants to go into nursing, she began perusing the programs at Marville and quickly realized that they did not have a nursing career track, so she joined the EMS track because it's "sort of along the line of medical". When I asked her how she liked the track, she told me, "I figured if it didn't have a nursing program here I could get some of my medical training and sort of see if I want to stay in EMS or if I want to go into nursing, but I think when I graduate I want to do EMS up until I can get my nursing degree and then go into that. I want to be a neonatal nurse." Emily is unique in that she actually plans to continue in the training that she received upon graduation, which as discussed earlier was uncommon in the students that are the focus for this study.

This ability to go with the flow seems to be a marker of Emily's identity performances at school. This was very evident in the ways in which she interacted with her tablemates (the Fabulous Four) on a daily basis. Emily's friends often blew off or scoffed at statements she would make during table discussions, and would routinely tell her to "go jump out the window" when she said something that they felt was wrong or off kilter. For example, Emily would frequently ask what was going on when group work was assigned, whether that was a reiteration of the directions or the conversation between her tablemates from moments ago. Her statements were often met with eye rolls, exaggerated sighs, and admonitions from the other girls. Emily's response was usually to laugh and shrug off whatever was said to her, and so the phrase "go jump out the window" became a normalcy for this group, so much so that the deeper implications of what that phrase might actually mean seemed to be a non-issue. However, this phrase 
shaped the ways in which Emily was a participant in her group. Because she knew that the girls didn't take her seriously, especially when it came to the academic side of any work that was completed at her table, she would often complete group assignments separately, chiming in every once-in-a-while with the group conversation, but usually only when the conversation was not about the work being done. Emily's past learning experiences also no doubt shaped both her participation and her responses towards the identities that were imposed upon her by her classmates. She describes this below: Emily: I'm not the brightest crayon. Ashley: Why do you think that? Emily: I don't know. It's like I know I'm smart and I can get the work done and I can do the work, but sometimes it's just ... I have my moments where I'm just ... I just get so confused. It's I know I can do the work and I know I'm smart and stuff, but I feel like other people just from some of my moments that I've had, I just feel like they're like "Oh well, don't listen to her." They think they're smarter and sometimes when I do put it out there they just sort of look over, but other times they do take it in.

Emily's moments of confusion, as she describes them, are those that her tablemates capitalize on as they talk at their table. Emily vacillates between using a metaphor in which she perceives she is unintelligent to stating, "I know I'm smart". Emily's beliefs about herself are clearly shaped by her interactions with her classmates, and discourse is a marker for this. Emily rarely feels heard in school, but has a number of moments in $\mathrm{Mr}$. Stark's classroom, discussed in Chapter 5, that highlight moments where Emily felt like 
she had a voice, and therefore performs identities across discourse practices that show the ways in which talk, by her or others, shapes her beliefs about herself as a learner.

\section{Taylor: "Everyone Knows Me As A Really Nice Person"}

Like Emily, Taylor's cheerleading aspirations drew her to Marville High School.

One of the first times I spoke to Taylor, she was wearing her cheerleading jacket, which was embroidered with her name and "Marville Cheer". The school's mascot was displayed on the back. Taylor frequently referenced cheerleading in conversation; she and Emily would often get into side conversations at their table about practices, stunts, and other members of their squad. Taylor's identity is intricately tied to her position as a cheerleader. Because she mentioned it so frequently, I asked her why cheerleading is so important to her and she said the following:

Taylor: Cheering for school, you actually support your team, and your school, and your reputation, and stuff, and I just like that.

Ashley: Are cheerleaders well known at Marville? Do a lot of people know who the cheerleaders are? That's part of who you are here at Marville?

Taylor: Mm-hmm (affirmative). I don't want to sound too cocky, but I am popular.

Ashley: That's okay.

Taylor: I like that, but I'm not in a mean way, because everyone knows me as a really nice person. I really like that. It makes me happy.

Ashley: You like to socialize with people?

Taylor: Mm-hmm (affirmative), in a good way though, not in a bad way or anything. 
For Taylor, the status of being a cheerleader is a marker of her identity at Marville, and she frequently performed this identity outside of the literal physicality of the sport. As mentioned earlier, Taylor would often reference cheerleading in class, both in casual conversation with Emily, but also in relation to schoolwork or how it shaped her as a person. She even refers to cheerleading as being an indicator of her reputation; however, this point seems to be complicated for her. She enjoys the fact that cheerleading means she is popular and knows a lot of people, but she is quick to note that this does not mean that she fits into the typical stigma of the popular crowd also being the "mean" crowd (as well as the cheerleader being an integral member of this crowd). This is a common labeling mechanism that can be seen across text productions throughout time, such as in young adult literature and movies, like Mean Girls or The Breakfast Club. In the words of Hannah Baker from 13 Reasons Why, "The popular kids are always mean, that's how they get popular." Taylor is perceptive of this colloquial understanding that being a popular cheerleader equates to being mean, or even snobby, and she reiterates twice that while she would label herself as socially outgoing, she only performs her popularity in a nice way. One of the ultimate ways that Taylor's understanding of herself as nice and popular came to fruition was being voted to the Homecoming Court as the sophomore representative. For Taylor, this was the equivalent of being told that she was well liked by the entire school—something that, as shown in the conversation above, is implemental to both her understanding of herself and the understanding of who she is by others around her.

Taylor does not live in the community of Marville, and so had to apply to get into Marville. In her words, they had to "check my test scores or something like that". Taylor 
lives with her mom and stepfather in a neighboring city community approximately fifteen minutes from Marville. She shared with me that her father is still in her life, and that they talk and see each other every so often. She also has a ten-year-old brother, whom she describes as "not one of those little brothers who's annoying or anything". As discussed earlier in this chapter Taylor wants to be a nurse, which is not an available career track at Marville, and so she is on the EMT track. She has plans to attend a university close by straight out of high school to study nursing while continuing her cheering career. While Taylor speaks fondly of school now, she has not always had such a viewpoint when it comes to her education. In middle school, Taylor attended a traditional school within the district. While many schools are traditional and not labeled so, the high variety of school types within this district (career magnet, Montessori, STEM magnet, etc.) means that traditional schools are often labeled in that way within their name. Taylor spoke candidly about her experience at a traditional middle school in the district:

Taylor: Mm-hmm (affirmative). Then, me and [my best friend] went to Mason Traditional. It was a big transition because I was never in a traditional program. Ashley: Yeah, it's really different.

Taylor: Sixth grade year, I had a meltdown. I was like, "I don't want to go here anymore. I'm tired of this," but my mom held me through it, and we got my grades up. I've never made anything below a $\mathrm{C}$ really. I've always been pretty average, A's and B's, and 7th and 8th-grade year was pretty good. Marville, I got here ... It became easier.

Traditional schools often operate under a "back to the basics" approach with a heavy emphasis on state-tested reading, writing, and math skills. Based on my own observations 
in traditional schools, teaching is often quite rigid and sometimes scripted. Students are often held to very specific rules and consequences, which is something that Taylor remarked she didn't like: "Yeah, and how strict they are. The work is fine. I can take work, but the standards you need to meet. They wouldn't let me wear earrings bigger than a quarter. They wouldn't let boys have hair past their ears. I just think that's taking away your character and making everyone try to look the same". Taylor says that she believes that the rigidity of the school environment takes away students' individuality. She had to wear uniforms, a marker of traditional schools that speaks to the consistency that is a guiding principle of the traditional school philosophy. Moreover, traditional schools often take a "back to the basics" approach in teaching and discipline.

When I frequently sat with the girls at their table, I never witnessed Taylor in a bad mood — she refers to herself as "the bubbly one". Taylor was always in the middle of conversation, but she also seemed to be the first one done with her work. She and Katherine, who I will introduce later in this chapter, were usually carrying on the main portion of conversation when it came to assignments. When I asked Taylor what she thought her role was at the table, she said:

Ashley: You're the reliable one at the table?

Taylor: Yeah.

Ashley: Yeah. Is that true when it comes to the assignments that you all have to do and stuff? Are you usually the reliable one?

Taylor: Mm-hmm. I'm usually the one to get it done first because I like getting stuff done. I feel incomplete if I don't have it done. 
Taylor's understanding of what schooling means - that you are given work and need to get it done with minimal questioning — has carried over with her from her traditional years. While she remarked that she feels this class was quite different from others in that Mr. Stark spends more time making sure everyone understands what is expected of them, Taylor still takes a very independent approach to completion. She usually was the first at her table to get things done, and she often vacillated between groupthink and independent performance. This might be the ways in which she performs two parts of her identity that are at odds with one another, being "really OCD" because "if it's not perfect, it's not working" and staying well-liked by everyone. In the next chapter, these identity performances will be analyzed in the ways in which Taylor participates in literature circle discussion.

\section{Ethan: "I Guess You Can Say I'm Pretty Smart"}

Ethan is the only focal student who actually lives in the town of Marville. Ethan lives on the edge of town with his mom and a younger brother and sister. Ethan's parents got divorced when he was six, and he shared with me that his mother has had many boyfriends since, some of whom were physically and verbally abusive to him.

Furthermore, alcoholism has been a large part of his life, both through his biological father and his mother's boyfriends. Recently, Ethan's father came back into his life. Towards the end of my time spent in Mr. Stark's classroom, Ethan was in a cast from a hand injury. His father had taken him to get the cast and that was the first significant amount of time they had spent with one another since his father was arrested for driving under the influence and subjected to court mediated rehabilitation. Ethan, who was in 
middle school at the time, and his siblings were in the car with his father at the time of the arrest.

Ethan, like many of his other classmates, will be the first in his family to attend college. His mother works as a medical transcriptionist and his father works as a heating and air mechanic (Ethan's grandfather owns the company). When I asked Ethan how he felt about this, he shared:

Ashley: Is that important to you?

Ethan: Yes. No one ever has been able to say the accomplishment of graduating from college and to see everyone else ... There's a lot of smart people in my family. To see all of them not accomplish that and then for me to be able to accomplish that, not only would that be proving something to myself, but everybody else that you don't ... It's something that you can do. I grew up in a drunk household. I was beat, abused. If you can get through all that and still graduate college, imagine what those people could do if they didn't have all that and they still had ... That's why I like to take pride in being smart, I guess. I don't use it sometimes.

One of the first things that Ethan shared with me about himself was that he wanted to go to medical school and be a neurosurgeon. However, later on in the year he also told me that he wanted to go into the military. These two career paths are representational of how Ethan identifies himself as both a student and as a person. Ethan's educational path before attending Marville High School was incredibly disruptive — he bounced around through multiple elementary and middle schools. He began at Marville Elementary, in the cluster, but then moved houses and subsequently moved schools. At this point he was 
living with his dad, but after he was arrested Ethan moved back in with his mom and once again changed schools. Ethan shared that he wanted to attend the one of the gifted and talented magnet schools in the district, but they were full at the time. At this point, he was back in the Marville cluster. This time was especially hard for Ethan, and he began to view school differently. He no longer wanted to apply himself, or as he says, "I started to get lazy and not care as much", and his grades dipped. For this reason, he also chose not to apply to any other high schools and matriculated into Marville based on his cluster. Ethan told me this was a decision he wished he could change in the beginning: "First month or two, I regretted it because I felt like I could have done something more if I had actually tried. I was upset but then I got used to it. A lot of my friends were here. I was like, 'Okay. This is where I want to go. I'd like to stay here.' I've just been here.”

Ethan is currently on the Law Enforcement track at Marville. He chose this track because of his future career aspirations to join the military, but also because he respects the men and women who work as law officers or military personnel. Interestingly, Ethan misconceives how this path would work out for him. He explained it to me in the following:

I want to go into the Marines as a combat medic and hopefully I can work my way up to a Navy Seal medic. Navy Seal medics are practically doctors. They perform minor surgeries and stuff like that on the battlefield. If I did that, I would come out of the military with not only... a veteran and medical schools that I don't even ... I don't have to go to medical school. All I have to do is ... No, that's not true. I have to complete one semester of medical school on major surgeries. Then 
after that, I don't have to do a residency or an internship. I get to go straight to being a doctor if I choose to.

His understanding is quite misguided, as medics in the military are actually trained to have the equivalent of EMT status. When they leave the military, they still must go through the exact same route that nonmilitary citizens do in order to become a doctor. However, I highlight Ethan's choice of career route because it speaks back to a primary way in which Ethan performs his identity: through the concept of work ethic. Not only did Ethan speak extensively to me about what work ethic means to him and why it is important to him, I also observed Ethan performing or rejecting his understandings of work ethic through discourse and actions in the classroom. This connects directly back to the complicated way in which Ethan performs and talks about being a student, as well as his future career aspirations. On the one hand, joining the military means that Ethan will be told what and how he will perform work, i.e. his ethic will be strictly guided by his commanding officers. In this way, Ethan's lack of work ethic is almost taken away from him, as he would not succeed in the military without it. This career path seems to fit Ethan's performed identity when he rejects work in the classroom, only in that it does not require Ethan to make any decisions about work. Further, Ethan may have chosen this path to combat this part of his identity, which he may feel at odds with. On the other hand, Ethan has mentioned going to medical school, which is a path that is on the extreme other end of work ethic in that, a person must be incredibly driven, successful in education, and self-motivated to succeed. This seems to fit the performed identity that Ethan has when he speaks about how smart he is, as well as his aspirations for college and why it is so important to him. 
Of all the focal students, Ethan had what I would describe as the most contentious relationship with Mr. Stark. One instance in which Ethan and Mr. Stark were at odds with one another during an observation will be highlighted in the following chapter.

\section{Jorge: "There's Multiple Ways to Get One Answer"}

I first noticed Jorge when he started talking about death in a table conversation. During one of my observations in Mr. Stark's classroom, students were working on writing "scary" short stories, although the primary goal of the assignment was to teach students how to build tension in their writing, removing them from the "jump out and gotcha" kind of stories. Students had been exposed to Edgar Allen Poe, amongst other writers, but were focusing their writing on photos from The Mysteries of Harris Burdick (Van Allsburg, 1984). The students were writing their stories digitally, via Google docs, and two weeks in Jorge had nothing typed in his document. When Mr. Stark was circling the room, he asked Jorge what was happening, to which Jorge replied, "It's all up here", knocking on his head with his finger. I moved over to Jorge's table, which he shares with Kassie (the focal student discussed next), and asked him what he was thinking about writing about. He immediately started talking to me about his preoccupation with death, which was tied intricately to his understandings of the Catholic religion in which he was raised. He revisited this conversation in a later interview.

Jorge: We're Catholic. My mom, she's more religious than ever. She's not, like, strict religion, but she follows the path of whatever, you know?

Ashley: Is it important to you?

Jorge: It's important to me, yeah, but as I grew older, I see it differently. It's not as much in my life as it was. You know, like I told you, I was thinking about 
death and stuff. I wasn't stressed out or nothing, but it was like, whoa, this is crazy, where am I gonna go? We're gonna die and where are we gonna...you know? That didn't get me stronger with it, it just got me confused. I'm still with it, you know, that's just me. I'm still with it.

Mr. Stark had shared with me that he would classify Jorge as a deep thinker who often got preoccupied with heavy topics, death being a primary example. As I came to see during my observations, this was also a way in which Jorge would participate through discourse in classroom conversations.

Jorge is the second child in a family of five children. He and his siblings live with their mother and stepfather in a community outside of Marville. Jorge's older sister also attends Marville. She is a senior and participates in a cooperative program where she leaves school to work for one of the large companies near Marville. Jorge's older sister has already been accepted to a nearby university. As Jorge said when I asked him if he would be the first in his family to go to college, “...my older sister beat me to it". When I asked him what he wanted to go to school for, he shared the following:

Jorge: Engineer, I was thinking engineer, go to engineer school, go to [the nearby university].

Ashley: Yep, they have a great engineering school.

Jorge: I don't know, it's like, scary to think of, like oh my goodness that's so much more school and other stuff and all this money, it's crazy. Ashley: It's worth it, though.

Jorge: Yeah. I was thinking, in the long run, all my friends will be like...they ain't trying to get to school and stuff, they ain't trying to influence me like that, 
but they're just like "Come on, you can do this, this, and that," construction gets you good money too.

Jorge's aspirations are quite different from many of his friends, and this may be with good reason. As noted earlier in this chapter, Marville trains many of its students to go straight into jobs within the community, most of which do not require a four-year degree. Because Jorge is in the Heavy Equipment track at Marville, many of his friends may also be following that path, with construction as a viable outcome after high school. However, Jorge also seems to want to ensure that he promotes construction as a respectable career as well. This is most likely because Jorge's stepfather works in construction and is the sole breadwinner of his family (his mother stays at home to care for Jorge and his siblings). Jorge and I spoke about his choice of the Heavy Equipment track in which he revealed that construction is not only a vital component to his family's well-being, but also ties directly into how Jorge views himself and his culture as a Mexican American. Ashley: What made you choose [the Heavy Equipment] track?

Jorge: Mostly because that's a hard working thing to be in, and my stepdad does it, plus I'm a Mexican, I'm here to...

Ashley: What does that mean?

Jorge: It runs in the blood!

Ashley: I don't believe that for one second!

Jorge: Nah, it's all that racist stuff...

Ashley: That's a stereotype, for sure.

Jorge, like Ethan, considers work ethic as intricately tied to both his future career goals and his current education. However, for Jorge, there is an added layer of his identity as a 
Mexican American. Jorge alludes to a common stereotype in the United States - that men of Mexican descent often work in manual labor jobs, construction being one major field. For Jorge, joining this track, even though it does not have any direct relation to his future career choice of engineering, may be a way for him to perform, for his family and others in his life, an identity in which he has much work ethic. Moreover, Jorge may also have purposely chosen this track to combat the common stereotype he speaks about below. Jorge: I'm running with it, that stereotype gets you money! I don't see it, like that stereotype stuff. I don't see it as an insult, "Build my roof," this and that. It's funny.

Ashley: Why do you think it's funny?

Jorge: Because it's true! I mean you see a lot of Mexicans and a lot of Latinos working on roofs and stuff. I find that funny, it's just our area, that's what we do, that's hard working. I'm proud of it, we're proud of it.

Ashley: I think it's really cool that you look at it from a work ethic perspective, rather than from a job perspective.

Jorge: Yeah, how's that an insult? How do you see that as an insult? "Hey, go build my roof!" Okay, at least I know how to build a roof, bro. Where you at? Why do you need me to build you a roof? I mean, that's how I see it. Jorge's response above is reminiscent of the ways in which Jorge performed identities through discourse across classroom conversation contexts. Jorge, who would often take on a leadership role in group conversations, frequently hit back at anything that he felt went against his own set of beliefs. Further, Jorge, who Mr. Stark often called "The Philosopher", would make statements that seemed to promote alternative discourses from 
the conversational status quo. In this way, Jorge's "philosophizing" would disrupt the cohesive or normative narrative that was occurring. Many times, Jorge's statements made him seem even wise beyond his years. One example of this is how Jorge sees his own future career in engineering: “...plus, I'm doing what I love, math, you know? Sometimes it gives me headaches, but for me, math is like...you solve things out, and that's life, too. You gotta solve things out in life. Sometimes you don't get the right answer. There's multiple ways to get one answer. That's what I love." This statement harkens back to the ways in which Jorge performs an identity of pushing alternative or multiple perspectives through talk in this classroom, which will be discussed in the next chapter.

\section{Kassie: "There Is Nothing Wrong With Re-Reading"}

Of all the focal students that I interviewed, Kassie was the only one that did not grow up in the city originally. Kassie and her family moved to the metropolitan city that Marville sits outside of from a large Midwestern city in August of 2016, right before the beginning of the school year. They chose the city for a fresh start: Kassie has two younger brothers, 12 and 13, who were having problems at their previous school (the 12 year-old had failed a grade, and the 13 year-old had failed a grade twice). In addition, Kassie's older brother who is 30 years old and works at a large grocery distribution center in the city had already lived here for a number of years. A single parent, Kassie's mother got a job at a car manufacturing plant in the city, working second and third shifts on the assembly line. This means that Kassie is often responsible for the care of her brothers - she stays alone with them multiple nights of the week and is frequently the one that ensures they get on the bus each morning. Unfortunately, moving here did not have an effect on her brothers' behavior; at the time I interviewed Kassie, the 13 year-old had 
recently gotten kicked out of his middle school and was attending alternative school. Because of this, family and friends were commenting on Kassie's home situation, which upset her: "they're not doing as well as I am. People like to say it as like my mom doesn't have home... it will be like we're not home trained or whatever. I'm like, "How did I turn out the way I did if we didn't learn home training?" Kassie is very protective of her mom. She talked extensively to me about how her mom has made many mistakes, some of which her brothers seem to be following. Kassie is in many ways a second mother to her brothers. Yet, she makes it clear that her brothers' behavior is not completely to blame on her mom. When I mentioned that it seemed important to her to be a good influence for her brothers she responded, "I try to. I really try to because...I'm not going to say it's like...I'm not explaining it right. My mom's a good influence. I'm not trying to talk down on my mom. I love my mom like to death, but some of the choices she makes, like they shouldn't follow them."

Kassie went through a lot of turmoil in her move, and she's still unsure as to whether she likes this new city. Sometimes, she wishes they would move back to where she grew up. Aside from her brothers, much of her adjustments came from the difference in schools. Earlier in this chapter, I noted Kassie's discussion of the ways in which Honors and Cambridge classes were run quite differently from her old school. However, the differences and challenges do not stop there. Kassie has aspirations to go to an HBCU, Howard University, when she graduates, which is both prestigious and very competitive. One of the requirements for that is three years of foreign language. Kassie had begun taking French at her old school, and she was told it would be offered at Marville. However, when she got her it wasn't, nor was she placed in Spanish, the one 
world language that was taught. This means that Kassie will likely take French online through the summer in order to stay on track. Further, Kassie's core courses are in a different sequence from those offered at Marville; she was placed into a core science midway through the sequence that she had never taken, but will be revisiting a core science next year that she already had. Much of this is due to the career tracks and the way in which courses are sequenced through them; as mentioned before, career track and course changes are no easy feat at Marville.

Kassie wants to be either a pediatrician or a lawyer who specializes in family services. Namely, Kassie wants to work with kids. She loves them and finds them to be "intelligent beyond their years". Kassie will be the first in her family to go to college. Her mother finished high school through a GED program; she became pregnant with Kassie's older brother ended up dropping out of high school as a result. Then, when she was gearing up to go to college when Kassie's brother was fourteen, she became pregnant with Kassie and so never enrolled. She later went to pursue her associate's degree but got pregnant with Kassie's brothers pretty consecutively. However, Kassie has a cousin who strongly encourages her to pursue higher education — she herself graduated from a large Midwestern university and is currently pursuing a law degree at Howard University. For Kassie, the prestige of this university means almost as much to her as getting accepted: Kassie: I don't want to go to anywhere with the name that has like a state in the name. It doesn't sound good to me. Like Virginia [sic] State, I'm like, "I don't want to go there."

Ashley: What is it about that that doesn't sound good to you?

Kassie: I don't know. It's just... 
Ashley: What makes you want to reach for a school like Howard or Harvard even?

Kassie: I don't even know. People will say, like, "You make your future" like the better school you go to, but that's not always true.

Ashley: Mm-hmm.

Kassie: That's not always true. You can be smart and go to any school, but I don't know. Maybe I'm trying to prove myself as smart or something because all of my life, ever since I was little, my mom has always told me like, "You're like a sponge. You absorb everything." I never believed her.

This conversation very much speaks to the way that Kassie's discourse imbues her identity performances in Mr. Stark's classroom. Kassie has very clear rules about language for herself. She doesn't believe in using slang, and often corrects herself when she slips up in conversation. She believes that slang makes her sound less intelligent. This is also a reason why Kassie enjoys reading classic literary works—she is fascinated by the beauty of the language that authors used during various time periods other than the modern. Further, Kassie would often play the part of the sponge in classroom discussion. It is important to note that I include Kassie here as a focal student, but she only shows up briefly as a participant for analysis in the excerpts explored in chapter 5 . She very rarely spoke out during whole class discussion and during literature discussions, she would often sit quietly, absorbing everything her classmates were saying. However, more moments that Kassie did speak out were not chosen for analysis because she was often not in conversation with other focal students, and she rarely participated in conversation in which tensions were present. For Kassie, this may have been a way to ensure that she 
was projecting the intelligent, confident, and successful person she longed to both embody and promote through language.

Katherine: "I Know Exactly What I Want, When I Want It, and How I Want It"

Katherine was the very first student in Mr. Stark's class to speak to me. On my

first observation, I was sitting in a chair in the corner of the room as students walked in. Katherine came straight up to me and said, "You can call me Rainbow, everybody else does." When I asked her why, she told me it was because she had blue hair. What I found most fascinating about this introduction is that Katherine had dark brown hair, with no rainbow like colors to be found. I immediately found myself interested in Katherine and how she presented herself. Katherine is the third focal student from the Fabulous Four, the group that I routinely sat with and of which Emily and Taylor belonged. Katherine made it very clear from the beginning that she was the leader of the group, and the girls treated her this way. I quickly found out that their nickname for her was "mom" for multiple reasons. Katherine was usually in charge of the group when it came to table assignments, she was fiercely protective of the other girls, and she was routinely quite bossy. It was obvious that being the mom was a role that Katherine thoroughly enjoyed but also took seriously. When the girls were working at their tables, Katherine would often steamroll through any conversation that wasn't meeting her (usually unannounced) expectations for what should be occurring and when. However, she would jump into unrelated conversation if it directly involved her. Katherine was the first girl that I heard tell Emily to go jump out the window.

Of all of the focal students, and out of the entire class, Katherine was Mr. Stark's most participatory female student when talking in class across contexts, in that there were 
very few instances where Katherine would not either lead discussion or respond to Mr. Stark and her classmates during discussion. Katherine had strong opinions on most every topic broached in class, but she was very strategic on when she would and would not share those opinions. Her level of sharing was usually characterized by traumatic occurrences outside of the classroom. For example, in the time that I spent in Mr. Stark's classroom, I witnessed Katherine physically upset over a number of happenings in her personal life. Early on in the year, Katherine's mother, with whom she lives, kicked her out. She classifies herself as estranged from her father. She was bouncing around her friends' houses for a few weeks before moving back in with her mom. On another occasion, Katherine came in upset about her boyfriend, who is 19, in the military, and stationed in the south. Katherine would go visit him often on weekends, and they had gotten into a huge fight. On a third occasion, Katherine came in very angry and said that the coach of one of the teams she participated on had kicked her off the team because she had failed to show up for practice. This happened during the point that she was kicked out of her mother's house and did not have any transportation to get to practice. When situations like this would happen, they would dictate Katherine's participation, the ways in which she performed her identity as a leader during discussion, and her interactions with Mr. Stark, which will all be highlighted in the next chapter.

When I first met Katherine, she was on the teaching track at Marville and told me she wanted to be a special needs teacher. However, about midway through my observations, she switched over to the Law Enforcement track. When I asked her why, she shared the following: "Well, I didn't necessarily switch because I still want to be a teacher eventually because once you go, after you get out of boot camp and stuff like that 
and you actually finally get somewhere that you're stationed where you stay until your contract ends, you can go to school or at least do online classes and stuff like that." Like Ethan, Katherine sees the military as a stepping-stone into her teaching career, and she has specific aspirations for how that will happen.

Katherine: I'm still going to go to school to be a teacher once I leave. If I'm in the air force for 10 years, let's say, I can come out with a master's degree in anything that I want.

Ashley: What about the air force? What draws you to hat?

Katherine: I have tons of friends who are in the military, so I'm surrounded by it. I thought it would just, not necessarily a backup plan because the teaching is my backup plan, but it's just something that no one in my, specifically my mom's side, that anybody's done. I'm the only kid who wants to do it and I feel like I have the kind of, I guess you could say a personality to do it because I'm really driven and I'm successful when I want to be. I have an attitude, but I feel like that, military specifically could help.

Ashley: Do you see the military as also being part of helping you to become a teacher?

Katherine: ...I want to actually feel like I'm doing something. To me, [teaching] is something that I've always liked to do, so if I can, along with one day wanting to help all these kids who have problems at home and can't learn outside of school, along with helping kids, I want to be able to help my country too. It's just basically expanded into what I actually want to do. 
Katherine's explanation above draws on a number of ways in which her identity is performed within the classroom, but also on the ways in which she sees her identity contributing to her future. Specifically, she mentions an attribute of hers that I observed when in the classroom-Katherine is incredibly strong willed, and so she performs her identity markers when she wants to. However, she also looks at the military similarly to the way that Ethan does, believing that the military can provide her with an "attitude adjustment" or, can reshape the personality traits which she feels both positively and negatively contribute to who she is. In Ethan's case, as mentioned above, this was his work ethic (or lack of). Further, joining the military is a way for Katherine to prove something to others, which is an aspiration that all of the focal students seem to allude to in their conversations with me- - each of them has plans to do something that others around them, especially in their families, has not done before.

Katherine has had a very interrupted and disgruntled experience with school, partially because of moving between parents as a child and partially because of her own descriptions of the schools that she attended. In fifth grade, Katherine's dad left the family, right before she was transitioning to middle school. She shared with me that there were many repercussions from his leaving: "I was just hateful. I hated everybody. I wanted nothing to do with anybody. I was never in class. I never ate. I never drank. I never slept. All I did was read..." It was at this time she took a course in middle school in which she worked with the special needs population at her school. She developed a strong relationship with many of the students in the class and so began her interest in teaching. These relationships were also a motivation for Katherine to change her participation at school, with teachers leveraging her time spent in the special needs 
classroom with her grades. While Katherine would not say she likes Marville (she feels like an outsider because many students had come to Marville in groups from other schools) she does attribute it to her current success in school. She shared with me that had she gone to another school within the cluster, one that she would have automatically matriculated into from middle school rather than applying like she did with Marville, she feels that she would be in a lot of trouble.

One phrase that Katherine said to me is, "I know exactly what I want, when I want it, and how I want it at such a young age, it's kind of surprising to most people..." This phrase perfectly describes the purposeful ways in which Katherine performed identities through talk in Mr. Stark's classroom. Katherine would both readily share her opinion, or become so standoffish Mr. Stark would bring attention to it, depending on her personal feelings that day. She was incredibly fierce in circle discussions, and would hold staunch to her own opinions, sometimes neglecting to consider others' perspectives. Further, Katherine would routinely perform an adult identity in the circles, either by trying to control what was happening or by participating in ways that showed she was older and beyond other students. Overall, the ways in which Katherine participated throughout different discourse contexts did not vary as much as other students who would perform identities that were markedly different from others across these contexts.

\section{Mr. Stark: “Am I Doing Something Bad As A Teacher?”}

Mr. Stark is not originally from the town of Marville, nor the city in which it resides. He comes from an opposite part of the state, in the Appalachian region of the country. Mr. Stark grew up in a small county surrounded by many more that are similar in fashion, with metropolitan cities being few and far between. In many of these counties, 
like Mr. Stark's, one can find the basic necessities of life: a grocery store, post office, and medical offices. This part of the country is commonly known for its factories and coal mining, and Mr. Stark's father has worked in one such factory for twenty years. His mother is an office manager for a medical office. They have been divorced since he was five years old. For all intents and purposes, the area that he comes from is quite rural. Mr. Stark describes Smith County below:

Mr. Stark: I'm from Smith County. It's three hours east of here. It's extremely redneck. It's actually like Marville, which is why I feel at home here. Ashley: When you say "redneck," what does that mean to you? Mr. Stark: For real? Ashley: Yeah.

Mr. Stark: It means people that wear camo, the hats with the hooks on them, tractors, hunting all the time, four wheelin', you notice I took the -g off of that. It was pretty much everything that embodied what I wasn't.

Mr. Stark describes above many of the activities that residents of his hometown would commonly take part in, such as farming and riding recreational vehicles, but these are activities that Mr. Stark did, and does, actively reject. In addition, he also uses the pervasive stereotype of "redneck" to describe those from this part of the country. For Mr. Stark, this stereotype describes everything that he tried to escape and feels that he does or did not embody. He even uses the phrase to describe his own brother, who is now a Marine. Interestingly, while Mr. Stark makes it clear that he wanted to escape the way of life that pervaded his hometown, he ended up in Marville, a community that is in many ways quite similar to Smith County. Yet, as Mr. Stark shared with me, he sees Marville 
as an alternate reality, or a variation of the reality that he has always known, from that of Smith County. He believes that while Marville has a small town feel in that everyone seems to know each other and those who grow up there often stay within the community (that being the reality he has always known), he believes that "there's still that city mentality or more artsy, creative, out of the box thinking rather than just conservative ideals all the time." The progressive understanding that Mr. Stark has of Marville may be due to its proximity to the urban city that it fringes; the area of the country that Mr. Stark comes from does tend to promote more conservative ideals historically, though I would not consider myself an expert to categorize it completely in this way. This understanding of a straddling of principles within Marville is a catalyst for Mr. Stark as a teacher. He strives to push his students to think outside of the box, as he's shared with me on numerous occasions. While he believes there is some pushback from parents regarding this (those that he believes still epitomize the conservative ideals he feels are present in many "small" towns), he also describes many of his students as “...willing to think and be outside the box. They're willing to challenge where they're from whereas Smith County was not like that. You don't challenge where you're from. You just adopt it." Mr. Stark's own experiences of challenging one's identity through place weigh heavily into his teaching decisions as he strives to challenge his own students to do the same, often through classroom discourse. However, this is not without its tensions, which will be highlighted in the following chapter. I emphasize his understanding of Marville in relation to Smith County, and the quote above, because they highlight the ways in which Mr. Stark speaks in dichotomies about his past, himself, his teaching, and his 
relationships to others. Below, I will expand on these dichotomies to further understand who Mr. Stark is as a person and a classroom teacher.

Mr. Stark described himself as "weird" on one of the first occasions that I interviewed him, stating that he is "not a normal English teacher". Pretty immediately into our relationship he began to share with me that he seeks to set himself apart from what he believes to be the status quo in his career. In fact, "weird" is a term that Mr. Stark used to describe himself on a very regular basis. Students would also refer to him as weird, but interestingly the word never took on the often negative connotation that one would assume; most students used weird as synonymous with the way in which one might lovingly refer to their best friends or siblings (i.e. "You're so weird!" while smiling and laughing). In Mr. Stark's understanding, he describes himself as an exotic animal behind bars stating, "I'm weird. I am sporadic", and he often compares his classroom to a zoo. The opposition of explanation here is a segue into how Mr. Stark sees himself as a teacher in relation to the larger world of education. In many ways Mr. Stark, and more specifically his classroom discourse, are exotic in the world of education. Visitors to Mr. Stark's room might see on any given day him jumping onto or standing on tables, using a megaphone to respond to students, or talking only in accents. Further, Mr. Stark gets into students' personal space. He would routinely poke students in the ear, place his face next to theirs when speaking to them, or even slice at them with a foam sword. Mr. Stark aligns himself so strongly with the idea of being different that he states he wishes other teachers would share his "passion and weirdness"; he believes that his way of being in the classroom could be beneficial to others, as he feels that students positively react to his weirdness in the classroom. 
It is difficult to describe Mr. Stark's way of being in a classroom to those who have never seen it. In many ways, Mr. Stark's behavior, when on paper, may sound borderline inappropriate; for example, in teacher preparation courses, candidates are taught NEVER to get close enough to students to be in their personal space. I can speak to my own feelings by saying there were moments in his classroom where my initial reaction was to cringe at his actions, and even sometimes his discourse. However, for $\mathrm{Mr}$. Stark, I can also truly say there seems to be an exception to the rule when it comes to his talk and actions. I never witnessed a student physically respond in a negative or uncomfortable way to Mr. Stark's antics, although I can't speak to their inner thoughts or feelings in the moment. Mr. Stark works incredibly hard at the beginning of the year to develop a specific kind of community his classroom as we discussed below:

Ashley: How have you put those norms into place in your classroom? I would venture to say that probably, is it fair to say that that starts at the very beginning, day one?

Mr. Stark: Well yeah, I mean I try. Like I go over it. All right, think about anything, you could tell someone like to keep their feet off the grass, but like that doesn't mean they're going to listen. I put up a sign at the beginning of the year that says, "Be polite, be respectful, give me effort," that kind of thing, you know they're over there. They're the most generic things you're going to hear, respect, effort, attitude, leadership, and then like making mistakes is cool, like I added that one to our reel, but those are just words on paper. Until we really start having conversations, I don't think it really sets in stone. 
This is not a typical educational community of (often one way) respect from students to teachers with an understanding of "do what you're told or there are consequences". In Mr. Stark's classroom, there appears to be a true mutual respect between teacher and student. In the entirety of my time spent in his classroom, including previous research that isn't directly contributing to this study, I never witnessed a student given school mandated consequences for their behavior. Rather, Mr. Stark had his own system for dealing with student misbehavior-more often than not if a student was disrupting class, Mr. Stark would pull them out into the hall and have a conversation with them, as he notes in our exchange above. This usually was enough to placate the student when they re-entered the classroom, and often would even change the student's attitude. Talk, and the way that it happens in his classroom, is important to Mr. Stark, and he believes that talk and/or actions are what his students are actually learning from.

One specific example of Mr. Stark using talk to promote classroom norms occurred one day with Ethan, who Mr. Stark routinely had conversations with about his talkative nature and lack of focus in class. On this day, Ethan was not contributing to the class assignment, in which students were stating their goals for the rest of the year; after significant unrelated conversation with his classmates, and repeated proximity warnings from Mr. Stark, Ethan put his head down on the table and refused to work. Then, exasperated, he wrote a note to Mr. Stark that stated, in the following numbered way:

1. I wish I stayed in comp classes.

2. I did no work in any classes.

3. I should stop coming to school.

4. I want too [sic] stop coming to school. 
5. I will eventually drop out of school.

He turned this in for his goals. After Mr. Stark took him into the hall to talk to him, he came back in and was quiet for the rest of the class. When I asked Mr. Stark about the situation afterward, he told me that he had asked Ethan if what he had written was what he really wanted. Ethan told him no and apologized.

Mr. Stark used this as an opportunity to speak to Ethan about the feelings he highlighted in his writing, while simultaneously ensuring that Ethan had a rationale behind Mr. Stark's behavior, rather than punish him for his misbehavior. I highlight this example to represent the atypical ways in which Mr. Stark responded to negative behavior in his classroom, but also how students reacted to Mr. Stark's response. While classroom management is a topic that is beyond the scope of this study, this example highlights how Mr. Stark uses talk in all facets of his teaching, including behavior, and also how this particular discourse might be atypical from a traditional educational viewpoint, in which teachers may have instead taken action and reprimanded the student with a physical repercussion rather than trying to seek out the root of the problem through conversation. This could have caused Ethan to further shut down instead of opening up to Mr. Stark about an issue at home. In fact, Mr. Stark credits his way of discipline—which includes taking students out in the hall to speak to them, rather than writing them up-as one of the ways he achieves success in his classroom. He also states that this is in direct contrast to the attitudes that most teachers and administration within his school carry towards discipline. He references a more traditional response when stating, "I don't want them to feel like you get in trouble, I'm gonna throw you somewhere and yell at you. 
Rather, it's—you get in trouble, you're gonna be-you're gonna be talked to, but you're also gonna learn a lesson from it".

Mr. Stark wants his students to see him as a person they can trust. He strives to create this type of community in his classroom so that "they feel comfortable here", which might also flow into the physical boundaries that Mr. Stark crosses regularly. Mr. Stark brokers this trust with his students specifically through discipline, as shown above in the example with Ethan. He shared, “I don't treat them like an adult who's angry at them. I treat them like-I kind of feel like a big brother to them because, I'm not that much older than them...I understand them, and that respect I think shows more than my, the things I do. You can tell the rapport versus the discipline, anger, and what not." Mr. Stark's classroom talk could be described, on any number of occasions, as sincere, sympathetic, and responsive, as seen above; I would also describe his classroom talk as colloquial, real, and informal, which he speaks to below in the ways in which he tries to form relationships with his students.

Mr. Stark believes he carries respect into the way he treats students on a daily basis saying, "I get to know my students". He prides himself in seeing his students as real, singular people, rather than a mass of adolescents that are inseparable. Mr. Stark shared, "I don't lie to them. I keep it very real with them, and they respect that. That's why my kids who aren't interested in English will still say this is their favorite class, because I don't lie. And, it helps them stay honest with me, too". Mr. Stark believes that his rapport with students increases their willingness to participate within his classroom. Ultimately, Mr. Stark has one mission when it comes to his students, and that is to teach them the importance of being a good person. He believes that "talking to them [people], 
respecting them, even if you don't like who they are" are the most important skills that he can instill in his students. In chapter 5, I will analyze how this belief in creating, promoting, and sustaining civil discourse is realized in Mr. Stark's classroom.

Through the many interviews that I conducted with Mr. Stark, it is clear that he has constructed a figured world of education that he sees to be at direct odds with his identity as a teacher. This figured world included the ways in which he views the current state of education as a whole existing. One of the ways that Mr. Stark negotiates the world of education is through discussion of what I will deem the key players. These are the people that Mr. Stark views as "running" education—administrators and those "at the top". Mr. Stark first brought key players into conversation when he stated, "I feel like the administration is like a super villain sometimes, and it takes a couple little people to say hey, this isn't the only way the world works". It is clear that Mr. Stark believes he is one of the "little people" who is standing up to the system. He also feels that there is an extreme disconnect between teachers and those at the top: “I just don't get-I don't know if the people who are making the standards were ever really teachers, or were teachers for the right reasons, but I also know they're not teachers now for a reason”. The key players are, for Mr. Stark, directly connected to data and testing, another overwhelming and pervasive topic within the larger world of education. Mr. Stark views data and testing as having a direct effect on all aspects of his teaching, including classroom management, community, and the relationships that he develops with his students. Mr. Stark believes, “you can’t test everything”, and is disgusted by how much testing encroaches on all aspects of his teaching life. In fact, Mr. Stark stated, "I know that standardized testing is not the answer everyone thinks it is. For sure data, we need it for schools and what not, 
but it's ruining kids' idea of school. It makes them hate being here". This was an interesting and dichotomous point in the conversation - while he does see data as a "necessary evil", and one that can be put to good use, he equates the process of acquiring said data to creating a breakdown of kids' appreciation for school. Mr. Stark feels that at his school there is "such a heavy focus on it [testing]", which is true in many public schools today. However, at the time of writing this section, Marville had gotten rid of a school specific routine assessment that they were conducting every nine weeks, which pleased him and made him feel that his fight was not all for naught. While Mr. Stark feels that being a teacher is truly part of who he is as a person, data and other bureaucratic duties do not fall under this umbrella.

Ashley: If there were any part of your job that you would describe as being counterintuitive to who you are as a person, what would it be?

Mr. Stark: Data. That's awful. Paperwork, I hate. Data, I hate. I can look at a bunch of quizzes to see that these kids aren't understanding this question. I don't need to look at a bar graph telling me all the kids got this question wrong. I guess it's helpful to have $33 \%$ of your kids don't know this type of question, so let's choose those kids for intervention. That's good. But I hate it. I want to teach. I don't want to ... I wish there was a computer that could do the rest of that stuff for me. Scour the data, tell me who needs what, and I'll teach those kids that stuff. For Mr. Stark, these portions of his job do not jive with the reasons that he became or wants to be a teacher. Another example of this is bathroom duty. As mentioned earlier, bathrooms at this school are locked at almost all times, and teachers must physically unlock them for students to use them. Further, Mr. Stark and his fellow 
teachers are often assigned to bathroom duty, where they stand outside of the bathroom to ensure that students aren't using the space to skip, smoke, or do any number of other forbidden activities. These duties and many more that comprise the bureaucratic, or paperwork, aspect of the career do not appeal to Mr. Stark, as they don’t for many teachers. However, they tend to make Mr. Stark physically upset, so much so that he is willing to voice those opinions to his students and his administration. At one point earlier in his career, he became so exasperated with the amount of testing in his school that he confronted his principal about it. He also regularly tells the students that he does not agree with the amount of testing they have to do, but that he has no choice in the matter when administering standardized tests. In fact, he told me that testing and data feel so counterintuitive that "Since I got to this school and started teaching I, my disgust for standardized testing has only increased, and it continues to do so, so much that it kind of feels like it's ruining my love of teaching a lot of the time".

Mr. Stark uses discussion in the classroom on a fairly regular basis to combat the notion of standardized testing and promote a facet of teaching that he does love. It is even, for him, a way to balance out the rote notion of factuality that is employed in testing - discussion does not keep the same constraints of standardization, nor does it have to rely on students having a specific incumbent knowledge about a myriad of subjects. Discussion in Mr. Stark's class, unlike standardized testing, often centered around one central idea or piece of literature. Students came into the circle with the knowledge of having read or not read what they were discussing, but were also encouraged to draw on personal knowledge and beliefs systems when speaking. Mr. Stark describes his goal for literature discussions below: 
Ashley: You opened the door of literature circle discussions [with your Honors class]. How do they fit into this? Because still discussion, but a different type of discussion. Why do you use them?

Mr. Stark: I use them because when I was in school, and when we would read books, we had to read a book and write a paper on it. I didn't learn anything from that. I hated reading books in high school. I was assigned 1984. Ask me if I read it. No, I didn't. Because I didn't want to read this whole book over two weeks, write a paper about it on something that I didn't understand, so I feel like the discussion number one, helps them to understand what's going on in the book. Then number two, all these diverse opinions, like when you say something that I kind of understand, I'm like "oh my god, that reminds me of this". Then we are now making mass connections. Everybody has different connections they're making. Everybody reads the book in a different way. Again, diverse perspectives and the way somebody who has immigrants in their family, versus somebody who has never had to struggle against racism, they're going to interpret books really differently. I think that's really cool. I'm a white dude. Your recorder can't tell. I'm very white. But they open me up to things I never thought of, never had to know what it's like to struggle in the ghetto. I've been poor, but I didn't have to fear I was going to be shot. That's pretty crazy. I think it's important to know how other people experience books, too.

Mr. Stark reveals a number of his beliefs about himself, the role of discussion in his classroom, and his students in the statement above. He has made mention on multiple occasions that he compares his own way of learning to what he asks his students to do. 
Mr. Stark did not consider himself a traditional student in that he could sit still, complete work quietly, and learn at his best through memorization and regurgitation. For Mr. Stark, he learned best when he was given alternative, often creative outlets to showcase his understanding. In that turn, he strives to provide his students with those opportunities as well, and discussion falls under this umbrella (Mr. Stark was never given the opportunity to discuss literature when he was in high school).

In Mr. Stark's classroom, he believes that discussion provides students with an outlet to gain more understanding about what they have read, an opportunity to hear different perspectives, and a way to collaborate on making connections between the novel and each other. Further, Mr. Stark believes that he learns both from and about his students in the process - one of Mr. Stark's many goals as a teacher is to get to know his students on a personal level, and discussion provides him with one such occasion to do so.

While it may seem from the description above that Mr. Stark is the model of a confident, energetic teacher who is using his classroom to fight the man, this is not always the case. Rather, Mr. Stark has many different tensions that occur for him in his career, a number of which he discussed with me. Some of these tensions are evident in the very way that Mr. Stark speaks - he would often make statements that he was nervous about what I might ask him or whether he was saying the "right" thing, as evidenced in our conversation below:

Mr. Stark: ...maybe that answered your question a little. I don't know. I don't know what I'm doing in here. 
Ashley: Now wait a second. You go from telling me exactly what you want them to do to now you have no idea what you're doing. How do you make that leap? Mr. Stark: I try not to define myself or put myself in a category. Ashley: Do you feel like I'm asking you to define yourself? Mr. Stark: I feel like your questions lead to wanting...this isn't bad. I kind of like it. I really like this exploration of what I think, but I don't know if I'm saying something right. Am I doing something bad as a teacher?

Ashley: What is right?

Mr. Stark: See, that's a great question, too.

Ashley: What is right?

Mr. Stark: I don't know.

This conversation highlights the contradictions, or dichotomies, that Mr. Stark used to speak about himself on a fairly regular basis. He would often vacillate between a certain confidence of what he was saying, doing, and being to a notion that he was an imposter blindly finding his way through the darkness of his field. This trickled into all aspects of his person - he would frequently question the things that he did in his classroom and, if they really bothered him, he would approach the people involved and seek to find a resolution to the issue. An example of this would be from Ethan above, whom Mr. Stark wrote to on Remind101 to explain his actions in the classroom on a specific day, highlighted in the next chapter. This is a highly unusual route for a teacher to take in response to a classroom occurrence, but Mr. Stark believed that it was an innovative and private way to seek a resolution, which usually occurred. Most teachers, for fear of a disbandment of authority, might stand by their decisions and move on from the decision 
outwardly, even if their behavior plagued them inwardly. It is also important to note that students would use Remind101 to text Mr. Stark seeking advice about personal or home issues they might be having, as well as the standard homework questions. Once again, a mutual understanding was in place of reciprocity.

It is in these moments where Mr. Stark questions himself, even alters his behavior from what he might have originally considered doing or saying, where I found a collision between his discourse of teacher self and the figured world of education he actively tries to fight against. In these moments, Mr. Stark sought to fit his discourse of teacher self neatly into the educational world that he feels at odds with. For example, while Mr. Stark made it clear that he felt the key players created hindrances for him as a teacher, there was an exception to the rule when it came to his own administration at his current school. He shared that his administration is supportive of him doing something different in his classroom. This included him "jumping on desks and being weird, so long as I'm not hurting anyone". Once again, Mr. Stark revisited his self-description of weird, but in this case it comes with the deeper meaning of administrative support. He furthered this idea by noting, "being weird works, and I love that my school is so okay with that". He made it very clear that he does not believe all of his ways of being would be as accepted in other schools. In fact, his own administration surprised him by this acceptance: "I never would have imagined that I could do the things I do or say and it would work as well as it does". He also shared that his administration allows him to try things that aren't always in line with school-sanctioned policies. Mr. Stark stated, "That's how my administration works with me, and that's awesome, but other teachers are afraid to do that stuff too". 
This collision of worlds is furthered by the validation that Mr. Stark feels within his career. This validation came from administration, as seen above, but also from students and parents. Parent validation comes in the form of kids talking about him outside of school. Mr. Stark had a parent respond positively to a phrase he uses regularly in his classroom; he shared, "it's nice to see that just because I do things a little differently that parents aren't freaking out'. This may speak to the openness that Mr. Stark feels is present in Marville but wasn't present in Smith County, his home community. While Mr. Stark stands by his Discourse of teacher self, he still consistently looks for moments of acceptance from others. Student validation for Mr. Stark occurs, for example, when he hears that he is their favorite teacher, even when they hate the class. He even directly shared, “That's my validation. I know it's working”. However, this validation does not come without its own challenges as Mr. Stark negotiates what it means for his understanding of himself as a teacher, as evidenced below:

Mr. Stark: I just don't want to...I'm trying to find that line in being a good teacher that gets the kids to open their minds and I just told them I don't want them to impose their beliefs on other people. I don't necessarily want to impose my beliefs on them either.

Ashley: Is that hard?

Mr. Stark: Yeah. Where does my beliefs end, teaching start? Ashley: Do you think your beliefs inform your teaching? Mr. Stark: Oh sure. I'm not exceptionally religious or anything like that, but I believe in people, and that's what I try to teach. 
Ashley: I noticed today that there were points in the conversation where it looked like you were physically having such a hard time not stepping in.

Mr. Stark: I just want to protect everyone.

Ashley: Is that fair?

Mr. Stark: No, you're right. I put my head in my shirt like a turtle.

Ashley: What caused those moments for you and why?

Mr. Stark: I knew somebody was going to be upset by it.

This specific moment of contrition happened during a circle discussion about the current political state of the nation (Donald Trump had just been elected president) and highlights the tensions that are present for Mr. Stark in his classroom. While he prides himself on being a teacher who provides students with a real-life, free thinking, not your typical educational experience, there were moments when talk got even too contentious for him. In these moments, such as that above, he would later express that he responded in a way he wished he wouldn't — for example, stopping talk of one student, thereby silencing him or her, to spare the perceived feelings or response of another. He even notes above that he is straddling a line between being a "good" teacher and still encouraging students to think outside of the box. I highlight this moment, centered on a circle discussion in his classroom, to note the collision of worlds at play for Mr. Stark. While his discourse of teacher self wants to promote one way of doing, being, and believing in his classroom, he still struggles with what that means in relation to providing his students with what he believes to be a status quo educational experience in which everyone else believes he is "doing his job". 


\section{Conclusion}

In this chapter, I provided brief contextual profiles of the community, the focal students and teacher of this study from my time spent in Mr. Stark's classroom. These impressions are in no way complete representations of who those above are, and should not be treated as such. Further, as identities are consistently performed as people try on, discard, accept, or reject them, I treat these impressions in a similar fashion: they are both performed through discourse and understood from my perspective. However, I also believe that these impressions provide a colloquial context from which to draw as I analyze talk from this classroom below. In chapter 5, I seek to analyze how both students and teacher perform the identities described above across different classroom contexts of discussion. Particularly, I will focus on talk from whole class discussion, literature circle discussion, and political circle discussion. Further, I will analyze the ways in which these moments of discussion develop critical (political) talk, encourage perspective taking, and

promote voice and agency. These contexts were chosen for a number of reasons including Mr. Stark's level of participation in the discussion; multiple focal students participating in the explored moments of discussion; and the ways in which these moments deviated from "typical" discussion that I observed during my time in Mr. Stark's classroom. 


\section{CHAPTER 5}

\section{AN ANALYSIS OF CLASSROOM DISCUSSION ACROSS CONTEXTS}

In the previous chapter, I provide contextual profiles of Mr. Stark and some of his students. I acknowledge that these profiles were created through my lens of understanding, and therefore do not completely or wholly capture each participant. Rather, I analyze the ways in which Mr. Stark and his students have spoken to me about who they are, who they want to be, and how they want to be understood. In this chapter, I seek to analyze the ways in which these identity performances I explore in chapter 4 shape classroom discussions across contexts; particularly, I will analyze both whole class discussion and circle discussion. Within this analysis, I will explore how students develop critical (political) talk and disagreement (all discussion contexts), engage in perspective taking (literature circle discussion and political circle discussion), and gain (or lose) voice and agency (all discussion contexts). Further, I seek to explore how both student and teacher identity performances interact with each other, specifically looking at Mr. Stark's role in conversation. I began by choosing examples that I felt were significant in considering how students identity performances, analyzed in chapter 4 , shaped discussion within this classroom. That being said, each of these examples are also moments in which multiple focal students were participating. Further, I contend that all of these examples 
have moments of disagreement, perspective taking, and power, agency, and voice; however, I highlight some more obviously than others as I move through these moments of discussion. For the purposes of this study, whole class discussions are constituted by times that Mr. Stark was choosing to address the entire class on a topic and inviting students into the conversation to respond to what he was saying. I characterize these as whole class discussions because the nature of talk was not one-way, such as Mr. Stark lecturing at students with no opportunity for them to engage in talk. I characterize literature circle discussions as those where students were participating in fishbowl discussions ${ }^{1}$ to talk about literature, which in the case of the talk analyzed below was two pieces of fiction, a short story and a novel. Finally, I characterize a political circle discussion as one in which students were given the opportunity to participate in a fishbowl discussion with talk surrounding the recent election, political topics (such as immigration), and their thoughts on the country's future.

To begin, I will analyze two occurrences of whole class discussion where Mr. Stark is directing talk; in these examples, I will focus specifically on the ways in which critical talk, and one student's perspective was shut down, as well as how this moment contributed to the silencing of this student's voice. These examples took place approximately two months apart from one another. The first example is a whole class discussion to introduce a unit on argument in the classroom, and the second is a whole class discussion that occurred one week before the 2016 presidential election. I will follow this by analyzing two instances of literature circle discussions where Mr. Stark is

\footnotetext{
${ }^{1}$ Fishbowl discussions occur when an outer circle of students looks in on an inner circle of students engaged in conversation (see Smagorinsky, 2008). During this study, students in the outer circle used TodaysMeet technology to engage in concurrent digital conversations. Transcripts of these conversations were not included in the analysis.
} 
both in and out of discussion. In these examples, I will analyze how disagreement occurs for the first time, as well as how students begin to engage in perspective taking. These examples took place approximately one month apart from one another. The first example is from the very first-time students ever participated in a literature circle discussion, and was considered a "practice" circle for them. The second literature circle discussion was the final discussion that students participated in over Lord of the Flies, approximately two weeks before the 2016 presidential election. Finally, I analyze a political circle discussion in which Mr. Stark does not participate through talk at all. This political circle discussion was conducted one day after the 2016 presidential election, and one week after the whole class political discussion noted above. In these moments of discussion, I will analyze how critical (political) talk and disagreement develop, as well as how students problematize perspective taking and silence each other.

\section{Whole Class Discussion}

In this analysis, I characterize whole class discussion as conversation that is inviting toward every possible participant in the classroom, but not delineated by whether each of those participants is active, meaning that as with many types of classroom discussion, there is not necessarily a requirement for speaking. Whole class discussion is often teacher led and, as explored in earlier chapters, characteristic of a repetitive I-R-E model of talk. In Mr. Stark's classroom, whole class discussion was infrequent in that in my observations, I rarely saw what I would characterize as discussion. More often than not, when any function of conversation occurred that was whole class directed, Mr. Stark would use the time to provide a short lecture on any given topic, followed by directions and student work time. This is typical of traditional classrooms where teacher knowledge 
is imparted upon students who are expected to bank that knowledge for future use. These moves may also be characteristic of Mr. Stark's understanding of the figured world of education, where he feels pressure to "fit in" and teach towards a test. However, one whole class conversation during my observations moved toward a direction of discussion that was not completely monologic or authoritatively situated; rather, Mr. Stark seemed to be seeking to create dialogic discussion among students, but tensions move conversation back toward Mr. Stark leading discussion. I highlight the first moment of conversation below as an example of what whole class discussion normally looked like while I was there, followed by whole class discussion that is characteristic of the first moment of critical talk in the classroom and the silencing of student voice. The following excerpt, from a whole class discussion in Mr. Stark's classroom to introduce students to mood and tone, is characteristically typical of what this discussion context normally looked like:

Mr. Stark: So tone is the way you think about the topic on which you're speaking, mood is the way you feel about a topic that you're reading or listening to. So, let's say [this guy] comes up to this girl and says oh my god you are the most beautiful person I've ever seen on this planet. I would love to take your hand and be with you until the end of time. You just make me feel like I'm floating ((pause)) I'm flying even. If I could I would give you the entire world. And then, the girl realizes OH MY GOD who is this creepy guy that just came up to me. I've never seen him before. This is Starbucks. Go $\downarrow$ away. Now, how did that, what he said to her, though $\uparrow$ sweet, what would his tone be? Let's start there.

Student: Creeped out. 
Mr. Stark: No his TONE, the way HE feels?

Katherine: Embarrassed.

Mr. Stark: Nah, he doesn't feel that way he went up to her and told her how much he liked her.

Ethan: Don't—wouldn't that be mood cause that's how he feels?

Mr. Stark: Nonono, tone is the way he thinks about what he's speaking about. Ethan: Oh, okay.

Mr. Stark: So tone is about the author or speaker=

Ethan: So he has a romantic tone!

Mr. Stark: =Exactly. Romantic tone so pretty sweet, really nice, it's positive, but that girl 's never seen him, how is she going to feel about this?

Katherine: Creeped [out.

Mr. Stark: [Creeped out, there's your $\downarrow$ mood.

In this example, Mr. Stark draws on both humor and a real-world example, two ways in which he often enacts his identity in the classroom, in order to ask an initiating question (lines 1-9). At this point, students had been given rote definitions for both tone and mood, which they had written down in their notebooks. This conversation illustrates Mr. Stark's use of questioning to reinforce concepts that he wants students to know-those which they will see on a standardized test later this year. In this example, he asked what he believed to be a known-answer question, however students did not respond with what he believed to be the expected answer. When students began throwing out potential responses to his question, he immediately and negatively (no) evaluated their response and once again tried to restate the question: "No his TONE, the way he FEELS" (line 11). 
Ethan's question, “[W]ouldn't that be mood cause that's how he feels?" (line 15) points to his understanding that Mr. Stark is looking for an ideal response, and when Mr. Stark rephrases the original definition, Ethan excitedly responds with what he believes to be the correct answer. In doing so, he receives positive evaluation from Mr. Stark (line 20).

Whole class discussion in this fashion typically involved one word evaluative responses from Mr. Stark, but many conversations would include evaluative language of the colloquial sort (i.e. "Bangin"; “Awesome”; “Woo Feelings!”). While this conversation may suggest little room for agency or open-ended talk, it served a specific purpose for Mr. Stark. Mr. Stark's teacher discourse sits at opposition between who he wants to be as a teacher and what he believes is expected of him based on his figured world of education. For Mr. Stark, this type of I-R-E driven whole class discussion served as a way for him to follow the traditional model of ingraining students with knowledge he knows they will later be tested on (i.e. tone and mood). A later whole class discussion spoke to the ways in which Mr. Stark sought to perform his "teacher I want to be" identity by attempting to allow students to have open discussion about a contentious subject: the most recent presidential election.

During class the day after the 2016 presidential election, Mr. Stark had initiated a whole class discussion about the current political state inviting students to participate by sharing their thinking, primarily because he had heard snippets of conversation from students across his courses. Donald Trump was elected less than twenty-four hours before this conversation, and with a high population of immigrant refugees and minorities in the school, tensions were high. Some students were fearful of what might happen given Trump's rhetoric, while others from the many blue-collar families in Marville lauded the 
appointment of a president who promised to shake things up. Ethan was one such student, and, as he often did, became a quick leader of this conversation with the rest of the class. Ethan began by presenting himself as an "expert" on the subject, stating that "Hillary Clinton would've actually won by the popular vote". Below in the exchange between Ethan and Mr. Stark, Ethan performs his perceived identity of the "smart one" in class that fellow students can look up to by providing "facts" that he knows about the election:

1. Mr. Stark: So if we went on $\uparrow$ popular vote, Hillary Clinton would have won

2. the election.

3. Ethan: By 2.3 percentage points.

4. Mr. Stark: It was one-it was super close.

5. Ethan: And the::n Donald Trump landslided her in the electoral vote.

6. Mr. Stark: Because he pulled some states they didn’t expect him to... $\downarrow$ like

7. Pennsylvania.

8. Ethan: Well, because they said if he didn't pull some of the states they

9. expected him to like Mitt Romney did, and Mitt Romney lost like Nevada and 10. Iowa. He said if he pulled those they would help him out and I guess he pulled 11. them.

12. Mr. Stark: Now what we're talking about are things that should be talked 13. about in a history class, electoral votes and that kind of stuff. That's not what 14. I want to talk about. I want to talk more about your thoughts, feelings and 15. worries.

Both Ethan and Mr. Stark perform identities through this conversation based upon their own beliefs about themselves in this classroom. As Ethan stated in chapter 4, he believes 
that his classmates perceive him as one of the smartest kids in the room, and he therefore seeks to prove his expertise through his knowledge about the election. Interestingly, like the knowledge he has about his future military/medical career, he is not completely accurate. Clinton actually won the popular vote by 2.1 percentage points. Moreover, Trump did win Iowa but Clinton won Nevada. Ethan seems to question his own expertise in this statement by cushioning his assertion with "I guess" (line 10). Mr. Stark's response to Ethan is characteristic of a whole class discussion that is predominantly teacher led. Mr. Stark has a specific direction that he wants the conversation to go, and it is clear in his response to Ethan that what Ethan is saying does not fulfill that. Not only does Mr. Stark seem to want to quickly move on from Ethan's knowledge about the election, however right or wrong, he also states that this conversation belongs in another classroom (lines 12-15). What surprised me about this reaction is that before the conversation seen above, a student had interjected Mr. Stark to ask him what the popular vote was, indicating that there may be a lack of knowledge about U.S. elections in general.

The exchange above follows Mr. Stark's dichotomous nature of understanding himself in that he wants to promote a classroom where talk is free, but he stifled the conversation here when it did not promote his agenda. Further, it is important to note that he does believe his agenda as helpful for students, but in talk uses the phrase "what I want to talk about" as a marker of future conversation direction. This points toward a whole class discussion that is highly teacher directed, thereby silencing further conversation about the intricacies of voting, a topic in which all students are not knowledgeable. He then went on to direct the conversation by saying, "I want everyone 
to feel comfortable with sharing how they feel, but here's where our debate is going to go, or our conversation for the next ten minutes or however long it's going to go". Again, Mr. Stark is controlling the conversation direction — while this happened throughout the semester with his guiding rules for circle discussions, this was the first time throughout my observations that I had ever seen Mr. Stark put a caveat on whole class discussion. He sought at this point to tightly constrain talk about politics, which may be because it is a subject that routinely causes tempers to flare. In doing so, however, he may silence students in myriad ways, including not only from sharing their own beliefs about situations but also from sharing information that they have but aren't sure is completely accurate. An example of this comes from his next conversation with Ethan. Mr. Stark was aware before this whole class discussion that Ethan was a Donald Trump supporter. Ethan would share his political opinions regularly with both Mr. Stark and other students, and many of his political understandings or beliefs were shaped by right-wing media and members of his own household. In this next exchange, Mr. Stark reticently calls on Ethan to share something:

16. Mr. Stark: $\uparrow Y e:: s ?$

17. Ethan: They have to ((pause)) you know how they have to fund their 18. campaigns? And like=

19. Mr. Stark: Is this about like your concerns for the future? I want this to be 20. about what's gonna happen.

Once again, it seems that Mr. Stark has decided where he wants the conversation to go, and he does not believe that Ethan's comments are on that path. Further, Mr. Stark's intonation changed when calling upon Ethan (line 16), which could indicate that 
he had already decided Ethan's comments may not fall in line with his perceived objectives for this conversation — namely to share thoughts, fears, and concerns for the future. Because Ethan's comments were what Mr. Stark considered invalid (as Ethan continued, he spoke in broad terms about both sides of the presidency), he is quick to shut down any further comments that Ethan might make (lines 19-20).

Mr. Stark also used this moment to "get real" with his students by sharing his own vote saying, "before we continue, I voted for an independent party, I voted for neither of them because I knew Donald Trump would take this state anyway. I voted for Jill Stein, not that I support all of her policies, but I just...didn't want to support either of them.” In this moment, Mr. Stark enacted the rapport he seeks to create with students by sharing something very personal with them. This was not the first time that he had shared personal information with them; however here he shares his political beliefs. The concept of whether teachers should or should not disclose their political beliefs is highly complicated, and for teachers should be a decision made as teachers consider their pedagogical goals. For Mr. Stark, the utterance above may be a way for him to further perform his "keeping it real" relationship with students. Further, he may have shared this information so that students would not believe that he favored one candidate over another in this conversation, yet he had shared with me on a number of occasions his disgust for Donald Trump. Although he says he didn't want to support either of them, as if to let students know that he is not biased in the conversation, it was clear throughout the rest of the conversation that he had great disdain for Trump. He used a disparaging voice when representing Trump's base (the same voice that he used when speaking about the rednecks from his hometown in Smith County) and their perceived conversations about 
Trump's policies stating, "We love—we don't want any immigrants, get 'em OUT!". This talk move speaks to the literal performative qualities that Mr. Stark embodies in the classroom. He routinely performs his "weirdness" through special voices, physical proximity, and physical movement, as discussed in chapter 4 . However, this move both performs his weirdness and asserts a broad stereotype/opinion about Donald Trump's constituents, which is one fallacy Mr. Stark spends a majority of this whole class discussion trying to disengage students from. Further, this utterance may speak back to the ways in which Mr. Stark is trying to escape the narrow mindedness he feels is an embodiment of growing up in Smith County. By providing students with the opportunity to openly discuss their political beliefs, Mr. Stark is both promoting and constraining an opening of world views in his classroom. As stated before, he values an openness of talk in his classroom, yet at the same time feels constrained by his figured world of education - this can be seen in the following exchange with Ethan, which was the catalyst for the political circle discussion analyzed later in this chapter.

As the conversation continued, students tried to gain agency through talk, but Mr. Stark continued to hold the reigns, as seen below:

21. Ethan: Well they had, they had evidence that Hillary Clinton was getting=

22. Mr. Stark: *From the Clinton Foundation*

23. Ethan: $=\mathrm{N}:: 0$

24. Mr. Stark: That's what you're talking about.

25. Ethan: $=\mathrm{N}:: 0$

26. Mr. Stark: $\uparrow$ Yeah

27. (class laughs) 
28. Ethan: I was GONNA say that they had evidence that Hillary Clinton was

29. getting money from Muslim companies, and Muslim like organizations to

30. fund her presidency because she likes foreign dignitaries she likes being

31. with foreign policies and stuff like that.

32. Mr. Stark: Now, you said two things that I want you to think about. You said

33. 个they have been saying, you didn't tell me who they are and you also said

34. Muslin organizations, but you didn't tell me who those organizations are.

35. Ethan: I don't [know

36. Katherine: [Like Syria $=$

37. Mr. Stark: Now that's fine [but this is exactly what I'm talking about. This exchange reifies the ways in which Ethan, Katherine, and Taylor commonly perform identities through talk in this classroom. This exchange begins with Ethan once gain asserting his intelligence by attempting to share information that he knows about the election (line 21). However, at this point in the conversation, Mr. Stark has already rejected Ethan's statements a number of times and therefore does not even provide Ethan the opportunity to make his statement. Rather, he cuts Ethan off almost immediately to assert not only his belief that he knows what Ethan will say, but also his dominance as the leader in the conversation (line 22). Ethan is clearly frustrated with Mr. Stark's interruption, and exaggeratedly says "no" multiple times, drawing out the word as if to silence Mr. Stark's rebuttal (lines 23, 25). As Mr. Stark continues to interrupt him, the entire class begins giggling at the exchange, which could be due to their understanding that Mr. Stark's interruption is an enactment of his teacher self, making a statement in a "funny" voice in order to use humor to subjugate his irritation (line 26). For Ethan, this 
seems to prompt him to exaggerate his use of GONNA (line 28), as if to respond to Mr. Stark's interruption by increasing his volume to assert both himself and his utterance. Rather than give students the opportunity to respond to Ethan's statement and bring in not only multiple perspectives but also other knowledge, Mr. Stark immediately corrects Ethan for his use of language, particularly his broad use of generalities (lines 32-34). The conversation continues below:

38. Katherine: ((to Ethan)) [I know what you're talking about.

39. Mr. Stark: This is obviously a pretty candid conversation but, when we do

40. discuss this stuff in the future [I want you to know exactly who you're

41. talking about.

42. Taylor: ((to Mr. Stark)) [You need to know WHO WHAT WHEN WHERE

43. HOW and WHY.

44. Ethan: They never gave any real names for it, they-they never=

45. Mr. Stark: If you can't find it [then it's not, it's not valid.

46. Katherine: [It's been-

47. Mr. Stark: Like we can't use it as an actual discussion.

48. Student: Katherine [says she knows.

49. Ethan: [Well because they had like reporters, like, I don't know it was-it

50. wasn't the New York Times it was like a newspaper article or something like

51. that? And they never, they never leaked the name of the companies, they

52. wouldn't say who they were.

53. Katherine: The — what are the major places? Like Syria?

54. Ethan: $\uparrow$ Yeah and companies in Syria. So, a lot of people were afraid that if 
55. she got president they would need favors and their favors would involve

56. them being allowed in the country [which would cause terrorism. So, a lot of

57. people were scared.

58. Katherine: ((to Ethan)) [Terrorism.

59. Taylor: How do you know that though that it would cause terrorism?

60. Mr. Stark: THANK YOU! 个Taylor brings up a good [point.

61. Ethan: [WELL, I'm just $\downarrow$ saying.

62. Mr. Stark: Now, hold $\uparrow u p$ !

At this point in the discussion, Katherine tells Ethan in an aside, "I know what you're talking about" (line 38). In this moment, Katherine is endorsing Ethan's statement with her own, a talk move that could promote peer to peer discussion but is silenced by Mr. Stark's overlapping statement in which he tries to make clear that he expects students to "know exactly who they are talking about" (line 38). Interestingly, Mr. Stark describes what is currently ensuing as "candid conversation" which he delineates from how he expects future discussions to go. Candid conversation could be thought of as open, sincere, straightforward talk; however, it is clear that Mr. Stark still seeks to put caveats on the conversation at hand through his repeated silencing of Ethan and directive talk. This may be due to Mr. Stark's fears about the subject matter, which he later elaborated on: "that's the danger of a conversation like this, these kids are going to get their ideas out, and they could be hated on because of those ideas, and I don't want that to happen." This statement also speaks to Mr. Stark's desire to protect the feelings of his students, which may fall under the larger construct of the importance of forming relationships with his students. Mr. Stark's responses to Ethan at this point in the conversation worked in 
two ways: he silenced both Ethan and Katherine's comments while simultaneously protecting students, a way in which he seeks to promote himself as teacher (line 47).

As Mr. Stark is speaking, Katherine, who considers herself an assertive leader of the classroom, good friends with Ethan, and based on my observations is often the most outspoken female during structured talk such as this, attempts to support both Ethan and his previous statement with her own (line 46). This occurs simultaneously as Ethan tries to further explain his own statement (line 44), but Mr. Stark swiftly cuts him off to make his own point about the way in which discussion should occur (lines 45-47). He once again uses Ethan's talk as an example of what not to do in this type of discussionnamely he does not want students to assert their opinions without facts to back them up. Something of interest to note is that Mr. Stark speaks to the students about biases in the media but also states that students should and can use media as a factual basis for which to back up their statements.

As conversation continued with Ethan trying to endorse his knowledge and Katherine simultaneously attempting to support Ethan's statement, Taylor enters the conversation to suggest that the 5 W's would be a good way to explain information in this conversation (lines 42-43). Here, Taylor seems to be "doing school" with her comment on a classic, commonly taught descriptive structure; however, her statement functions in a number of other ways. As described in chapter 4, Taylor sees herself as someone who is well-liked by everyone in her school life, including both peers and teachers. In this moment Taylor may have been performing the role of good student in order to continue to situate herself as a well-liked student by Mr. Stark. Further, Taylor likes to project herself as the confident, knowledgeable other in discussion. She prides herself on being a 
high performer and hard worker in the classroom. By responding with the $5 \mathrm{~W}$ 's, she is able to situate herself as knowledgeable of school-based practices. Yet, she does so in such a way that she seems to be responding to Mr. Stark rather than Ethan's comment, as if she is searching for teacher acceptance in this moment that she has said the "right" thing.

While Taylor responds to Mr. Stark, Ethan also continues to try to explain his previous point, but Mr. Stark maintains his silencing efforts. Katherine once again tries to endorse Ethan's statement but is also abruptly cut off (line 46). Interestingly, a student who is not the focus of this study chimes in to state "Katherine says she knows" in an effort to bring in a third validation of student talk occurring (line 48). This student may understand that Mr. Stark's silencing efforts were not allowing for Katherine or Ethan to further explain themselves. This student's support for Katherine and Ethan may have also triggered a silencing of Mr. Stark, because he stops talking and allows for Katherine and Ethan to have an exchange. As Ethan explains that he does not actually have the information that Mr. Stark is looking for based on what he read, Katherine seeks to support him by continually asking him questions that may lead to the information she believes Mr. Stark wants. In this way, Katherine works as a broker of language between Mr. Stark and Ethan. Ethan seems to feel more agency in the conversation at this point, raising his voice to begin making his point (lines 54-57). However, Taylor steps back into the conversation, playing the role of Mr. Stark as she asks a question that is much in line with the statements and questions Mr. Stark has been making up to this point. Taylor once again takes on the good student role but also challenges Ethan in this moment, much like Mr. Stark has been (line 59). While Mr. Stark ignores Ethan's previous statement, he 
responds to Taylor with praise (line 60), signaling that he may value her questioning technique over Ethan's information, which he has devalued the entire conversation. Ethan seems frustrated at this point as he loudly comes back with "I'm just saying" (line 61). In this conversation, Mr. Stark and Taylor have both challenged Ethan's performed identity of "smartest kid in class", and it seems by the end of the conversation that Ethan has been silenced to the point that he no longer feels agentically capable of sharing the knowledge he thought he had. Remarkably, while Ethan makes multiple statements about what "they" (others) were saying about the election, these statements were taken as his opinion by Taylor, who asks how he would know terrorism was caused, not how the writers of the story would.

Towards the end of the discussion, students had been giving their opinions for some time about different political topics such as the building of a wall between the United States and Mexico; assertions in the media that Hillary Clinton was taking money from terrorist organizations; and the state of welfare in the nation. As seen above, Ethan has been driving much of the conversation, with Mr. Stark repeatedly responding to him that he could not make the statements he did without factual information to back them up. Below, is Ethan's final statement, which brought the conversation to an abrupt halt:

63. Mr. Stark: You're the last thing, and then I want to say some things to wrap 64. this up.

65. Ethan: She said about how it would cause more poverty and stuff, if you take 66. away the welfare system, but a lot of the people on welfare are like high 67. school dropouts and people who don't have jobs= 68. Mr. Stark: STOP 
69. Katherine: [That's a pretty big accusation]

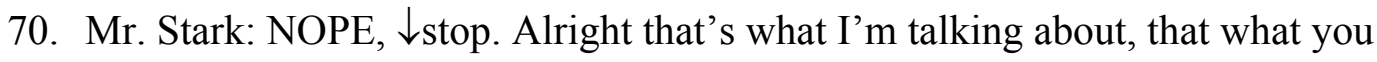

71. just said, su::per opinion, unless you have a fact you can't say something like

72. that. Because you don't know. You don’t know that at $\uparrow$ all. And while I will

73. give you the opportunity to look these things up when we form arguments

74. later=put your phone up=that's not what you're doing right now to throw that

75. because as you see you just offended someone.

Ethan chooses to make an admittedly broad and stereotyped assertion in this conversation about those who are on welfare (lines 65-67), an assertion that may come from his family's own political beliefs, but could also come from the familiarity of his own or others' experiences on welfare. Further, this was the only point in conversation where Ethan's statements seemed to change from another's perspective to his own perspective, i.e. he takes ownership over the idea. However, most markedly this statement may have been a performed, projected understanding of Ethan's own identity as it relates to work ethic. As stated in chapter 4, work ethic is something that Ethan grapples with, and so his statement here may speak to what he believes can be a result of not having work ethic: dropping out of high school and not being able to hold down a job, a reality that many of Ethan's own family members face. In summation, this statement could have been one in which Ethan's own identity struggles and his beliefs about politics collide. However, Mr. Stark immediately stops Ethan even before he finishes his statement (line 68). Mr. Stark not only makes a number of assumptions about Ethan, but also rejected and then shut down Ethan's assertion based on his own identity (Mr. Stark had shared with me that his family could have been on a welfare program but his mom 
worked multiple jobs) in this interactional context. Mr. Stark strives to create a classroom where talk is open, yet when talk became too real in the sense that a student made a highly inflammatory statement he immediately shut down both student led talk and the student himself, thereby silencing him in the discussion. Further, Katherine tries to step in and take on the teacher role by questioning Ethan's statement (line 69), which may have promoted discussion to continue between the students, but Mr. Stark interjects during her statement as well, thereby also silencing her. He continues on by asserting that Ethan doesn't know whether this is actually the case and telling him that he can't make a statement like that (lines 70-75).

When I asked Mr. Stark about this interaction later he said the following, "I felt bad stopping [Ethan] knowing what he was going to say. I knew it, not because I can read minds, but because I know Ethan as a person. I know how he likes to push buttons. That's why I had to put very specific rules up [during the circle discussion]. But I thought about it after I did it, and I sent him a message on Remind to apologize and said, 'dude, I didn't mean to shut you down. Here's why I did it." This was not the first time that Mr. Stark had reached out to Ethan on Remind after class to explain his behavior, which speaks to one of the ways he performs his understanding of the role of teacher by believing he needs to consistently make sure students know why they are reprimanded, silenced, etc. I should also note that he uses Remind to expand on other things: "It's not always what I did. It's maybe I should have said something to this kid for saying what he said.” Mr. Stark's confliction in silencing Ethan was almost immediately evident after this occurrence, and Ethan's reaction was quite obvious as well. He spent the remainder of class disrupting other students who were working and did not do anything assigned that 
day. Mr. Stark's use of Remind to talk to students speaks to a number of ways in which his identity is presented to students. He is provided with a way to atypically use an educational platform, it is a way for him to show that he cares about his students, and it is a way for him to seek out the validation that he wants as a teacher. As seen in chapter 4 , Mr. Stark vacillates between believing that he is doing teacher right and feeling like an imposter. By reaching out to students in this way, he is able to seek out reassurance that he has "done the right thing" or attempt to repair any wrongdoings he feels has occurred in his classroom. He explained his thinking by stating, “...yes, there are times I go home and think wow, I should have done something differently. If I can't send the kid a message, I will try to address it the next day. I write those things down before I write my lessons down because just like I want them to be aware of other people's perspectives, sometimes I have to realize I have to be aware of theirs too and no I don't know why Ethan is upset when he comes into my class. I want to, but I also don't want to pry into his life if he's not willing to open up to me. I guess it's like give and take.” In this statement, Mr. Stark does seem to recognize that there are other forces in Ethan's life that may shape not only his participation in the classroom, but also his talk. His consistent self-reflection about talk in his classroom speaks to his promotion of himself as the type of teacher he seeks to be (one who values multiple perspectives and student connections).

As mentioned earlier, whole class discussion in Mr. Stark's class was quite rare. During most of my observations, what little discussion that did occur at the whole class level functioned as the norm presented above: students were given information and then asked questions that were immediately evaluated. This information was usually test related material, and was preceded by a short lecture from Mr. Stark. This status quo of 
whole class discussion may lead to a better understanding of why Mr. Stark began the political discussion analyzed above with the intention of having an open-ended conversation only to find that he was primarily both corralling and silencing conversation when he felt it became inflammatory or contentious. Further, the ways in which these participants performed their identities within whole class discussion not only dictated the talk but also the interactions between one another. In the next section, I will analyze literature circle discussions, another context of talk in this classroom, but one in which Mr. Stark is both in and out of conversation.

\section{Literature Circle Discussion}

None of Mr. Stark's students had ever participated in literature circle discussions prior to entering his classroom. When I asked the focal students to describe their previous experiences with literature in their English classes, they would often talk about individually completing worksheets that contained comprehension questions about a novel they were reading. However, this was not Mr. Stark's first time conducting literature circle discussions in his classroom. Discussion was taught as a learning component during his teacher program and was something that he had utilized in his classroom ever since his first year. When I asked Mr. Stark what his goals were for literature circle discussions as an important component of students' learning in his classroom, he shared the following:

[Literature circles] make them think. Like, I could ask them comprehension questions like every other class has ever done, and I made them do for homework when they read Lord of the Flies. You show me that you can read words on a page, but you don't show me you can do anything with those ideas, or incorporate 
them into your own life. I mean, that's why we read books, we don't ... I mean, yeah, sometimes to escape ...

Mr. Stark alludes here to one goal he has for literature circle discussions, which is to gauge student understanding from the standpoint of his own belief that there should be real world application in his class. Further, literature circle discussions give students an opportunity that they don't get in other classes and, as many students mentioned they never got, which is to talk about what they are reading. As mentioned before, Mr. Stark also uses literature circle discussions to promote students' speaking and listening skills, which serves a two-fold purpose for him. From a "good teacher" perspective, it fits into Mr. Stark's figured world of education in that it is a required component of his curriculum. From Mr. Stark's perspective of the teacher that he wants to be, literature circle discussions allow him to create a space where he seeks to promote student to student talk, as well as the appreciation of multiple perspectives. With all of Mr. Stark's beliefs about the benefits of literature circle discussions, he does not believe that they are always a positive, beneficial experience. He alludes to that in the conversation below: Ashley: You mentioned that with comprehension worksheets, you can tell them it's right or wrong. Is there a right or wrong way for students to be in a literature circle discussion?

Mr. Stark: I mean yeah, there's definitely the wrong way, but it has nothing to do with the content of the book.

Ashley: What's the wrong way?

Mr. Stark: The behavior, right? Like you can't tell someone they're ... I mean, if they're like clearly wrong like, "Her name is not Jane, it's Katniss," yeah, you can 
tell someone they're wrong there, but you can't tell someone that their opinion is wrong or their life experience is wrong. You can't tell someone they're stupid because they think something differently than you do. I think if anything, it really teaches them how to handle a conversation in the real world.

Ashley: How do you mitigate those kinds of things happening in your circles, in your classroom?

Mr. Stark: I prepare as best I can, but they're going to happen anyway. First, I'll have rules, so we'll go over expectations. We practice this, so on like small scale, and then we go big scale and see what happens. It's a science experiment, like how you test anything. We had to figure out cyanide was poisonous somehow, so like somebody ate it.

For Mr. Stark, there is a tension that arises when student talk becomes contentious, which was seen in the previous section during whole class conversation on politics. This tension is also present in literature circles when Mr. Stark feels that students are being disrespectful of one another on a personal level. However, he repeatedly uses the word "wrong" above in talking about the ways in which students shouldn't contribute to circles. Mr. Stark may be speaking here of students insulting one another's life experiences and out of school knowledge that they bring into the circle, but he also makes an interesting point about how talk is shaped by others. Mr. Stark may seek to create an open classroom for talk, but at the same time he also seeks to only have talk that is, by his understanding, sensitive, appropriate, and productive. When talk does not fit these guidelines and places Mr. Stark into a zone of discomfort he often stifles it, which was 
seen above in the political conversation with Ethan. This can have powerful ramifications on the ways in which students perform their identities through discussion.

Further, Mr. Stark is very intentional that students should follow specific rules of discourse in literature circle discussions by posting them each time; however, this does differ from what students know to be rules of whole class discussion. Below, Mr. Stark discusses how talk might be connected between whole class and literature circles.

Ashley: You know you said you have these rules in place about how you want students to speak in literature circle discussion. Do you think that that's just kind of like part of the literature circle discussion like, "What happens in lit circle discussion stays in lit circle discussion."?

Mr. Stark: No way.

Ashley: Or, do you think that that speaks to what's going on in your classroom in a larger capacity?

Mr. Stark: Yeah, I mean we talk to people every day, like a literature circle is just a really easy way to give everybody a common thing to discuss and have a conversation about...it gives us a way to learn to talk to each other, learn to bounce our ideas off of one another, build on other ideas, like accept the fact that maybe our ideas aren't as good as other people's, or maybe they are and we just haven't polished it enough. Then once they leave the literature circle, like they know that I'm not going to let them talk trash about a kid anyway. Like you know how to have a conversation with someone, you know how to listen to someone when they're speaking and actually evaluate what they're saying rather than 
saying, "Nope," before you've figured it out, respecting each other. I feel like it's all stuff that's applicable to life.

From my observations and speaking with Mr. Stark, these rules for literature circle discussions were never explicitly brought over into whole class discussions. Rather, it seemed that Mr. Stark thought the carryover would occur naturally, which he indicates above. Mr. Stark did have rules about being respectful and other universal ideas posted in the classroom, but these rules seemed just that: highly universal and not talk specific. While some could argue that if these rules were universal they would be applied to talk, being diligent about talk norms is common practice, often referred to as accountable talk. Mr. Stark promotes these talk rules each time discussion occurs, changing them only slightly for the political discussion, which is seen in the next section. For Mr. Stark, a primary goal for the way in which students participate in discussion would be that these talk skills carry over not only into other discussions in his classroom, but also into their larger ways of talking in the world.

During the literature circle discussions analyzed below, students are reading Lord of the Flies, a teacher selected text for its theme of savagery versus civilization. Mr. Stark chose this novel because he believed that it fit into the overarching theme that he wanted to explore that year, which was what happens when society changes or falls apart? $\mathrm{He}$ also wanted to begin a sequence of novels with what he felt was easiest, gradually moving the students from LOTF to Hunger Games and, finally, 1984. Interestingly, most students shared with me that they did not like the novel, mainly because of its unfamiliar language. Many also felt they could not relate to the novel. I had also mentioned to Mr. Stark that I wondered why he chose Lord of the Flies because it is actually normally 
taught before $10^{\text {th }}$ grade, although like any literary text, that's negotiable. He said the following about the sequence: "let's give them a lower level Lord of the Flies book, and we'll see what ideas we can come up with. Next we're reading Hunger Games. That's sure as hell not 10th grade. Then we're going to get into 1984 . It's a gradual, let's try this book this out. Let's read a book that I know you're familiar with and you can see some ideas in it. Then let's read this one that we should read, and those ideas from both of them are definitely in this one." Mr. Stark's choices might be thematically related, but they also speak once again to the dichotomy that exists between being the teacher he wants to be and fitting into his perceived figured world of education. Once again, these worlds collide as he chooses books that have both literary merit and widespread popularity. He even states that 1984 was chosen because students "should" read it, which may speak to the highly regarded nature of this book and its place in high school English curriculum. Interestingly like LOTF, students also pushed back against his choice of Hunger Games. Most complained that they had read the book multiple times, but Mr. Stark continually asked them to try to read and discuss from a thematic lens. Mr. Stark was unperturbed by their complaints. In fact he shared:

"Let them tell me they didn't like it. I don't believe them. There's no way they would've been as passionate as they were in the circle if they didn't like the book. Kids tell me all the time they don't like the stuff I teach. Who does? What kid wants to come to school to learn pronouns and commas? None. When you get to have a discussion, I think that's what they like. They like that they get to have an opinion about something. That's cool. That's so cool. Let them fight to the death over whose side is better." 
When I asked students, many agreed with Mr. Stark's statements above, except they shared with me that even though they didn't like the material, what they did enjoy was the opportunity to disagree with their classmates, though their understandings of what disagreement was differed from one another. However, most students seemed to be in agreement that this happened in circles when students would disagree with and push back on one another; analyzed below, this was not a marker of the circles from the beginning.

When students first began participating in literature circle discussions in Mr. Stark's classroom, they would often follow the I-R-E pattern of talk that had been most likely modeled for them throughout their educational careers. As stated above, this pattern was also quite common during whole class discussion in Mr. Stark's classroom as well. Mr. Stark was very aware of the development, or lack thereof, of talk in the literature circle discussions, and this development seemed to dictate his level of involvement in the circle. For all intents and purposes, I would describe Mr. Stark's talk participation as both in and out, rather than the all in talk or leader of discussion that was seen in the whole class discussion above. While Mr. Stark sought to create dynamic, dialogic discussions amongst students in the circle, it was also clear that he wrestled with silence (a component of circles that is not necessarily negative) and would often intervene at these points to get students "back on track". It was in these moments that Mr. Stark might also push his own agenda, which often coincided with starter questions that he displayed on the board, although students were also asked to bring their own questions into the circle. It is also important to note that Mr. Stark had students practice being in literature circle discussions twice, with unrelated material, before they actually began 
participating in circles related to the novels they were reading. Literature circle discussion rules were:

- Ask questions

- Discuss ideas of text

- Provide thoughts/opinions

- Build on others' ideas

- Provide textual evidence

- Provide relative personal experience

- Encourage others

- BE POLITE

These rules were prominently displayed and repeated by Mr. Stark prior to each circle. Interestingly, many of these rules are markers of dialogic discussion, including uptake, understanding that there are multiple understandings, and encouragement of others' ideas. For Mr. Stark, they speak to his beliefs about who he wants to be as a teacher in the classroom and what he wants students to gain from being in his classroom. Many of these rules, and Mr. Stark's use of literature circle discussions, stem from his belief that students should learn there are multiple perspectives in the world and that not everyone will agree with those perspectives. Although Mr. Stark strives to construct this type of classroom space, tensions naturally arose throughout conversation contexts-literature circle discussions were not an exception.

As mentioned before, no students had participated in literature circle discussions, or any type of circle discussions before Mr. Stark's class. Below is a typical example of what student discussion looked like during the first few circles as students were 
acclimating to what this type of discussion might look, feel, and sound like. Students are in their first literature circle discussion based on the short piece "The Censors" (Valenzuela, 1988):

1. Katherine: I mean, I'm in that position right now [living far from a significant

2. other], not countries but states.

3. Steven: ((to Katherine) $) *$ So what would you die for?*

4. Katherine: I mean, I don't know=

5. Emily: She wasn't put in that $\uparrow$ position!

6. Katherine: $=I ' m$ not in that position.

7. Mr. Stark: ((to Katherine)) Now, place yourself there.

8. Katherine: If I was to be put in that position yeah, probably.

9. Mr. Stark: There we go. Now, $\uparrow$ why? Why is love so powerful?

This exchange highlights how students began talking with one another during their first literature circle discussion. In this exchange, Katherine is answering a previous question from Mai about long distance relationships (line 1). After Katherine's utterance, Steven immediately changes the subject by introducing a new question (line 3). There is no uptake of Katherine's previous statement and, while the question was directed at Katherine, Steven does not seem to acknowledge her previous statement. Katherine's initial statement is one of confidence: her boyfriend is much older, Katherine visits him frequently, and so therefore she can position herself as an authority on long distance love. Further, Katherine often performs an adult identity in the classroom, promoting herself as someone who is much older and life knowledgeable than her classmates. However, Katherine seems reticent to answer Steven's question, which may be due to its intense 
and personal nature. As she begins to waiver, Emily also steps in at this point, almost protecting Katherine, and counters Steven's question. When Katherine, who usually performs the identity of a leader and is quick to confidently throw out her ideas, becomes flustered Emily seems to take on Katherine's usual role by challenging Steven, something that she shared in chapter 4 she does not do with her tablemates (and friends) (line 5). However, in later circles this becomes a pattern in Emily's performed identity within the circle. At this point in the conversation, Mr. Stark immediately interjects (he is sitting outside of the circle) and takes up Steven's question, asking Katherine to “place herself there" (line 7). Mr. Stark seemed to appreciate the open-ended and personal nature of Steven's question, and he expected students to respond. When Katherine hesitated, Mr. Stark challenged her and she gave a reticent, yet sincere response. While there is not necessarily a "right" or "wrong” answer to this question, Mr. Stark validates Katherine's response and raises another open-ended question (line 9). In this example, Mr. Stark may have been modeling for students both what he believes to be the "right" type of question for circle discussions, but also the ways in which students could build on one another's ideas, both of which come out of the rules he provided.

These exchanges were very common in the first few circles. Students seemed restrained when asked personal questions, and would often jump from subject to subject with little uptake of one another's statements. Further, Mr. Stark would strategically step in not only when silence occurred, but also when he wanted to push students in a specific direction. In the exchange above, which came from students' first literature circle discussion, Mr. Stark seemed to focus more on students doing a good job and figuring out how to participate their best in the circle. He was mainly concerned that students may not 
take the circle discussion seriously. As students progressed into discussions focused on the class novel, Mr. Stark's emphasis seemed to change in that he intentionally promoted text to self and text to world connections, rather than only considering function over format. Further, as students spent more time in literature circle discussions, the conversation shifted from a repeated question-answer pattern to a more dialogic form; I will unpack an example of this shift below. Moments of disagreement that occurred in the circle were most remarkable in that almost every focal student emphasized these as both climactic and definitive markers of a productive literature circle discussion. Additionally, these moments of disagreement were catalysts for students' identity performances as they sought to participate (or not participate) in discussion. In the following exchange, students are in their second literature circle discussion from Lord of the Flies. During this discussion, Mr. Stark chooses to sit inside the literature circle with students. It's important to note that Emily, Taylor, and Ethan are the only three focal students in this circle. Immediately from the beginning, Ethan takes on a leadership role in the circle, asking the first two questions in succession. The following exchange shows the first moment in a circle in which students disagreed with one another:

1. Emily: Do you think if they=

2. Ethan: Because ((throws hands toward Emily to speak))

3. Emily: =Do you think if they come back together Ralph and Jack will

4. eventually start working together like split the leadership or do you think

5. they'll just fight?

6. Manuela: Honestly, no, I think like=

7. Ethan: One will $\uparrow$ have to be the leader, one will have [take over. 
8. Manuela: [I think Jack is too big headed $=$

9. Ethan: His ego?

10. Manuela: Yeah after he got to Piggy he just thinks he should be on top he 11. should be the leader.

12. Ethan: His ego is killing him because he's trying to drive forward everything

13. whereas Ralph is more laid back so he can take a step back and look where

14. everything is going okay and then when he sees something wrong, that's

15. when he steps in.

16. Emily: I honestly think that's where the problem is with Jack cause Jack's

17. just like if it's not my way I don't [want it.

18. Ethan: ((shakes head yes)) He's blinded.

19. Emily: Ralph tries to keep everything civilized and organized=

20. Taylor: ((to Emily)) And like other people's opinions too like the [inaudible]

21. he likes knowing what other people are thinking how they want their

22. "community" to be.

23. ((Ethan audibly sighs.))

24. Emily: That's why they ((moves two fingers up and down as if to show 25. discord)).

The conversation above was one of the first moments in literature circle that any students disagreed with one another, and Ethan got audibly excited. Ethan, Emily, and Taylor all participate in this circle by performing identities that were discussed in chapter 4. However, Emily also rejects a described part of herself through participation. Ethan perceived himself as the leader of this circle from the beginning, and he takes on that role 
by asking a number of questions but also by interacting with his classmates in particular ways, such as giving Emily the floor when they both try to speak at the same time (line 2). Further, Emily, who shared that she normally takes a back seat in conversation because she feels that when she does talk she is often overlooked, became agentic by asking a number of questions in the circle, including the question above, advocating for her speaking rights (line 3-5). When Manuela begins to dominate conversation, Ethan continually inserts his talk into her utterances by interjecting her or echoing what she is saying, which could be a way for him to hold his privileged position as conversation leader (lines 6-15). The conversation continues below:

26. Ethan: I know this doesn't have anything to do with the text or anything but

27. in the Persian war with the Greeks, uh the Spartans, the Spartans and a group 28. of farmers, they don't get along at all but the Spartans have 300 men against 29. an army of 100,000 Persians. And they had to work with a bunch of farmers 30. and fighters had to come together to beat an army of $100,000 \mathrm{men}$. So, food 31. ((holds out one hand to the side)) fighting ((holds out other hand to opposite 32. side)) they had to work together ((brings hands together)) to win so, they

33. have to...

34. Manuela: But what happens after, like say they win, are they just back to 35. their old ways?

36. Ethan: I mean you can but they still couldn't do it by them-- $\uparrow$ neither one 37. could do it by themselves. Ralph is not going to be able to get through the 38. storm without Jack. Jack is not going to be able to get through the storm 39. without Ralph. 
40. Manuela: Yeah but after the storm, they're just going to separate again.

41. Emily: What are they getting Ethan?

42. Ethan: $\uparrow$ Survival!

43. Taylor: I guess I agree with you Ethan because like it's like balancing them

44. out like savage ((holds one hand palm up by head)) civilization ((holds

45. opposite hand palm up by waist)) they both need each other ((moves hands

46. side by side in middle)).

47. Emily: Yeah, and they have these certain traits that the other one needs.

48. Manuela: But what happened after the storm? They'll go back to it.

49. Ethan: As long as they got through the storm. They've gotta get through the

50. storm first.

51. Manuela: Yeah, Exactly.

One of the most interesting points of this conversation occurs when Ethan brings in the example of the Spartans and Persians fighting one another. Yet again in a possible attempt to perform the "smartest kid in the class" identity, Ethan is misinformed about what he is sharing (lines 26-33). Most particularly, the 300 Spartans, who were Leonidas' men, worked with a total army of over 4,000 men to defeat the Persians; it was only after many of the Greeks from the main army retreated that the 300 Spartans, 700 Thespians, and Leonidas attempted to defeat the over 20,000 man Persian army, but they actually failed. The battle ended with the Persians beheading Leonidas' corpse. However, regardless of the misinformation this is a moment of agency for Ethan in the conversation. Not only is he able to share knowledge that he believes he has but his classmates do not, he is also one of the first students to make a connection in the circle to 
another text. Ethan's statement may also be a reflection of his beliefs about work ethic. Here, Ethan argues about working together to solve a problem, and is endorsing the belief that problems can be solved when parties who may not agree with one another can put aside their differences. This is a challenge for Ethan in school, because he shared with me that he does not always put forth the work he knows he can when he doesn't feel compelled for the cause.

It is here that Manuela pushes back on Ethan's statement, one of the first times it has happened in these literature circle discussions (lines 34-35). Like the whole class discussion explored above, Ethan seems to yet again get frustrated when he does not feel that he is being heard (lines 36-39). Manuela's statement actually serves a two-fold purpose of challenging Ethan and changing the direction of the conversation. While Ethan tries to make a specific point about the challenge of working with people who are different from you (a challenge that he feels in school), Manuela seems to be pushing back on him specifically about the aftermath of that challenge. At this point, Taylor interjects in agreement with Ethan, which may be her way of brokering a truce between them and projecting her own "well-liked by everyone" identity on the situation (lines 4346). Emily, in a position of comfort with Taylor her tablemate, also steps in to provide support for Ethan (line 47). Ethan then seems to articulate both Manuela's and his point about challenging situations, and the disagreement comes to a close (lines 49-50). Yet moments later, another comment is made in disagreement with Ethan, and he gets visibly excited that it happens as do Taylor and Emily, seen below:

52. Ethan: But you survive the storm, THEN you can think about what happens 53. but you gotta survive the storm first. 
54. ((conversation continues briefly))

55. Ethan: *yes, finally* ((in response to another student disagreeing with him))

56. Taylor: Good [job.

57. Emily: [Finally somebody disagrees!

58. Ethan: This is what I've been WAITING FOR, oh yeah hold on this is what

59. I've been waiting for. Ok, so you disagree=

60. Taylor: Wait!

61. ((everyone talks at once))

Many of the other students in the circle expressed similar excitement, through sound and body language (leaning forward, pumping fists). Ethan's excitement at disagreement in the circle may hinge upon his own self-understanding. When I asked him why he was enthusiastic about the disagreement, he said the following:

I like participating in them with the people who talk because I like to argue. If you have a point and I have a point and I think I'm right, I'm going to do everything I can to prove to you that I'm right, even if you think I'm wrong. Even if everybody else thinks I'm wrong. I think I'm right, so I'm going to do whatever it takes to prove to you that I'm right until I get solid, hardcore evidence that I'm wrong.

Ethan's perseverance in discussion has been examined twice in this chapter, specifically in thinking about how Ethan gets frustrated when he feels that he is not being heard. In Ethan's case, not being heard happens when he asserts himself as a knowledgeable source only to be misunderstood by others. In both cases, Ethan continued to push back when his statements were rejected by both Mr. Stark and Manuela above. Ethan was almost always 
confident when using talk as a tool in Mr. Stark's classroom. He was eager to assert his opinions and viewpoints into conversation. On the flip side, Ethan rarely completed written work. Discussion was a basis for Ethan to not only perform his identity as knowledgeable, but also a way for him to embody work ethic through his leadership qualities in discussion. Mr. Stark echoed Ethan's own understandings of himself saying, “He's really passionate about what he does. He's super thoughtful, but he just ... He doesn't want to do the [written] work". This passion comes through as he seeks to prove himself through discussion.

In the next session, I will explore a circle discussion that was focused on politics. During this discussion, Mr. Stark does not participate in any way, therefore only student voice drives the conversation. Further, I will explore how disagreement evolves during this type of discussion.

\section{Political Circle Discussion}

One of the final circle discussions that I saw in Mr. Stark's class was a two-fold anomaly: it was the first circle that Mr. Stark did not intervene in any way, and it was not centered around literature. Rather, this circle was a political discussion, with Mr. Stark's goal to give students the opportunity to discuss not only their political views but also their feelings on the current political climate (President Trump had just been elected). This circle stemmed from a conversation that had happened the previous week in whole class discussion, analyzed above. After the previous conversation became somewhat inflamed, Mr. Stark and I debriefed afterward. When I asked him why he stopped the conversation he said, “I don't know, that's bad isn't it?". He shared with me that he is always fearful that students are going to get their feelings hurt in his class. However, he 
then immediately told me that he also believed that by stopping the conversation he was stifling student voice in his classroom, even if it was for the sake of another student's feelings. Out of these divergent understandings, he decided he wanted to give his students the opportunity to talk about politics in a circle discussion (similar to the literature circles seen earlier in this chapter), but ONLY after they had done research about their views. He also decided that he would engage in risk taking by not intervening in in any way, shape, or form (this is the first time that Mr. Stark did not speak to students while inside the circle). Only students would drive this conversation. Before students entered the circle, Mr. Stark gave them the following discussion rules:

- Be respectful

- Understand that your perspective is not the only one

- Discuss the issues and how they impact us as people

- Try to stay away from "politics" (my side versus your side)

- DON'T GET ANGRY WHEN SOMEONE DISAGREES WITH YOU

Some of these are rules that students had seen in previous circle conversations; others, like the rule of trying to "stay away from "politics", stemmed from the very beginning of Mr. Stark's idea to have this circle discussion: the whole class discussion analyzed above. I highlight this conversation below to show a discourse context without Mr. Stark's presence and the ways in which his students perform identities within this circle as they talk about political topics. In the first circle, Katherine, Ethan, Taylor, Emily, Jorge, and Kassie are all participants. Mr. Stark projected the following questions for students to consider, which he said were based on interests that students had shared with him in the past week. 
- What are your personal fears/concerns about the next four years?

- What can WE do to ensure our country thrives?

- How are women supposed to feel with a President who has made such rude comments towards them?

- Is it fair for a president to eliminate previously made laws that he/she doesn't agree with? (Roe v. Wade-abortion)

- Should ONE person be able to eliminate progress made in areas like LGBT rights?

- Is it fair for one group of people to impose their beliefs on another group of people?

While some of these questions are quite open-ended in nature, others seem to speak to a stance that Mr. Stark already has taken within politics; therefore, even though he is not participating in this discussion through talk, as a teacher he still shapes the discussion through his production of questions. While these questions were projected, they were not immediately addressed. Conversation began with brief talk around whether a war would begin under Trump's leadership, and progressed from that. I highlight the conversation below to explore the ways in which participants situated themselves at the beginning of this discussion on politics. Some students immediately performed identities that seemed to promote participation structures similar those in other discourse contexts, while other participants performed identities in contradiction to the ways in which they have participated in talk previously.

1. Katherine: Yeah, aside from all the negative stuff, specifically that social

2. media has posted, did anybody else ever pay attention what he could do for us 


\section{3. [ $\uparrow$ positively?}

4. Jorge: [ ((shaking head affirmative)) Yeah okay there ya go.

5. Katherine: Because I feel like this...

6. Taylor: In like a biased perspective do you, in order to have trust in your

7. president...like I don't support Trump or Hillary so I'm being TOTALLY

8. biased with this but you have to at least give him a chance to show what they

9. can prove or what they can do good $\uparrow$ or bad.

10. Katherine: ((looking down)) A lot of people are scared because he doesn't

11. have any politician, any kind of experience other than the fact that he's a

12. businessman.

In whole class discussion previous to this conversation, Katherine had shared that she was pro-Trump because her mother was voting for him, even though she wasn't sure if that was how she felt. Further, she shared that she wasn't sure how else she could make a political choice because she felt entirely uninformed in the process. In this case, she incites talk with a poignant and directed question that she knew went against the status quo (lines 1-3). Only a handful of students at this point had expressed pro-Trump views - one of whom was Ethan. Many other students had blatantly stated they were proHillary or had said they wouldn't choose either candidate, as Mr. Stark shared was his own voting choice (he voted for Jill Stein). Katherine positions herself as a dominant lead in the conversation, as well as someone who isn't afraid of conflict, by asking this question. Katherine considers herself aggressive, and would often perform this identity within classroom discussions, as seen in other conversations in this chapter. Jorge provides affirmation to her response, most likely because he hopes that it will open up 
conversation beyond a rehashing of previous occurrences, which was not the case (line 4). Taylor then performs her "good student" identity by stating a caveat of being biased, most likely in response to one of Mr. Stark's directives to try to have a factual conversation (lines 6-9). Further, she weaves her own lack of support for either candidate into the conversation, a talk move that she may hope keeps her both really nice to and well-liked by everyone, which she shared in chapter 4 is how she believes she is perceived by others. Overall, Taylor is in fact bolstering Katherine's statement, but she does so in a way that situates herself in opposition from Katherine; Katherine asks a direct, pointed question while Taylor takes an indirect (and ironically non-biased) path to ask the same question. This may have caused Katherine to reconsider the value-laden statement she said previously, because her next statement seems to imply a possible negative consequence of Trump's election (lines 10-12). The conversation continues below:

13. Jorge: And because of what he said before. [He hasn't said some good stuff.

14. Katherine: [Yeah.

15. Katherine: Okay but neither has $\uparrow$ Hillary!

16. Jorge: Yeah, I was going to get to that. We shouldn't judge somebody, they

17. say some stupid stuff.

18. Ethan: No one cared about what he said until he ran for [president.

19. Jorge: ((thumbing at Ethan)) [Yeah, right!

20. Katherine: [Exactly see!

21. Jorge: We're bringing up irrelevant [stuff.

22. Manuela: *[No one cared because he wasn't becoming the president of our 
23. country. [He was just one of those rich men.*

24. Jorge: [Right, he's the, he's gonna be the —or he is the leader of the

25. [country now.

26. Ethan: ((to Jorge)) [And so NOW ten years ago counts for something because

27. he said one thing?

28. Jorge: I mean, I'm not trying to say nothing I'm just ...

29. Manuela: And deleted emails counts for something? That was just about her

30. daughter's wedding?

31. Emily: Ooohhhhhh.

At this point in the conversation, Jorge subtly built off Katherine's statement to add more evidence of possible negative outcomes of Trump's election: his routinely inflammatory talk (line 13). This is also a performance of identity for Jorge in that he is promoting an alternative to the current discourse, a frequent talk move for him, and also making the conversation more global with a moralistic statement about judgment. However, Katherine may have taken Jorge's statement as attacking, because she immediately came back with, "but neither has Hilary" (line 15), signaling a reversion back to her original pro-Trump statement. Jorge, who routinely sees himself as a mediator and not as someone who is ready for a fight, immediately agrees with Katherine, adding that he was "getting to that" (lines 16-17). It was clear that Ethan had been waiting for a point to join the conversation (line 18). He had shared with Mr. Stark that he was reticent to attend class at all today, if only because he knew conversation would get impassioned and he didn't want to insult anyone, per his RemindMe conversation with Mr. Stark. However, as politics is a topic that Ethan is clearly passionate about, he quickly joins the discussion 
by seeking to bolster evidence for Trump's inflammatory language use, which Katherine and Jorge both agree with. At this point, Katherine, Jorge, and Ethan, who are all established leaders in discussion, are driving conversation.

As conversation continued, Manuela quietly inserted herself into the discussion to make a point against Ethan's earlier comment about Trump's previous talk (lines 22-23). As in previous discussions analyzed above, Manuela disagrees with Ethan but does so by building off of his statement through a subtle contradiction, rather than blatantly disputing his point or stating her disagreement. Jorge, who has been in agreement with most statements up to this point, also shares agreement with Manuela by developing her statement, insinuating that it matters now because "he is the leader of the country" (lines 24-25). Ethan, who is a known Trump supporter, tries to push the disagreement further with a common debate among politics at large: what actions matter and for how long? Further, he uses his own knowledge of a common rebuttal to Trump's language use (lines 26-27). However, Ethan's retort to Jorge made him take a step back in conversation, which could be because Ethan had raised his voice at this point and moved into Jorge's personal space (they were sitting right next to one another in the circle) or because Jorge felt that the conversation was reaching a point of tension that he felt unready to deal with. Manuela, nevertheless, continues to push back on Ethan's statement, referencing Hillary Clinton's email scandal from the election (lines 29-30). At this point, Ethan's argumentative stance seems to embolden Manuela as a participant in the circle, which may be due to her knowledge of Ethan's staunch support of Trump or her own disparaging political beliefs. Her statement is followed by an "oohhhh" from Emily (line 31), signaling an "in your face" or "she got you back" understanding (line 30). While 
Emily has normally taken a leadership role in circle discussions up to this point, she too may be feeling the tensions that are arising from the conversation. For Emily, when tensions like these occur in discussion, such as at her table with her friends, she often chooses to either stay out of the conversation completely or project her own nervousness through deflective talk, which may be occurring here.

Emily's utterance looks to antagonize Ethan, because he responds to Manuela by asking her for proof, seen below:

32. Ethan: Can you prove 'em, did we see the emails though?

33. Manuela: Well they say that it wasn't [the only thing that was...

34. Jorge: [They [say but what is it? They can't be proved because...

35. Ethan: [THEY SAY, exactly, they can't prove-they're $\uparrow$ deleted, THEY

36. CAN'T SEE IT!

37. Manuela: [Okay, but there's video footage. There's video footage-

38. Katherine: [Remember to not be attacking.

39. Emily: [Stick to the election $\downarrow$ guys.

40. Jorge: Alright, alright, alright. Back to the point of us and our country

41. because of...

42. Katherine: Her emails.

43. Jorge: Her emails and what people said.

44. Taylor: That's her mistakes okay? It's over and done with. It's mistakes.

45. Emily: *Do y'all delete text messages?*

46. ((circle laughs))

47. Jorge: Right, ya'll [said some stuff]? Everybody's said some silly stuff 
48. before.

Ethan's statement in the above exchange asking Manuela for proof is critical in that it speaks to the ways in which Ethan's talk about welfare was handled by Mr. Stark in whole class conversation (line 32). When Ethan made a sweeping statement, Mr. Stark told him he must have proof before stating something so broad. At first glance, it may seem that Ethan is merely modeling talk based on previous discussions; however, I would argue that Ethan is also performing his identity as knowledgeable other in this situation, as the next few utterances point out. This statement was a way for Ethan to build to a critical piece of evidence to support his view: that many of the emails in question were deleted by Hillary Clinton and therefore are contents unknown. Manuela seems to respond how Ethan expected, by using "they", which further speaks to his participation in whole class discussion with Mr. Stark. As soon as she makes her statement, both Ethan and Jorge respond similarly, talking over one another and disparaging her use of "they" (lines 34-36). However, as Jorge seems ready to bring evidence about why proving the contents of Clinton's emails would prove fruitless, Ethan, who is physically excited and has raised his voice at this point, uses Manuela's own language against her, practically yelling “They can't see it” (lines 35-36).

This was the first of many points of hostility in the conversation, and as tensions rise Katherine performs her leader identity by reminding Ethan that he should not attack another student in the circle (line 38). Her statement may speak to Mr. Stark's rule of not getting angry when someone disagrees with you, however she is also performing her mom and adult identities. Her utterance was stated in a caring affect and it also completely redirected conversation, which is similar to the ways in which Mr. Stark's 
statements operated when he was participatory in a circle. Emily also chimes in to bolster Katherine's statement, but she may also feel reassured by Katherine's identity performance as her mom identity was often performed during their group work (line 39). Additionally, Jorge resumes his leadership role and tries to revert conversation back to a more democratic level of engagement (lines 40-41). Interestingly, Katherine seems to try to direct the conversation back toward Clinton's email scandal (line 42), but at this point Taylor enters the discussion seeking to shut down this strand of conversation. Taylor's phrase, "That's her mistakes okay? It's over and done with. It's mistakes" (line 44) could be a projection of her own performed identity that reputation means everything. For Taylor, being well-liked and known as nice are the most important qualities she possesses, and her statement here performs these identities as she seeks to end the disagreement, thereby keeping everyone friendly with one another.

As this moment in the conversation comes to a close, Emily makes a subtle yet brilliant connection between the conversation and her classmates by asking, "do ya'll delete text messages" (line 45)? It seems that once tensions were alleviated (albeit for a short period of time) in the conversation, Emily once again felt that she had voice in the circle discussion. As the whole circle laughs, a laugh of recognition and agreement, Jorge capitalizes on Emily's statement by revoicing her question, thereby supporting and recognizing Emily's contribution to the conversation (lines 47-48).

As the discussion progressed, students focused on the topic of abortion, and the conversation was exclusively driven by Katherine, Taylor, and Jorge, with no other participants speaking. However, Katherine became frustrated with the lack of participation and introduced the following question, "How do you feel about a president 
who recently, not in the past, he's made negative or derogatory comments towards both sexes and all kinds of different activities that are included and races?" Students begin to grapple with this question below:

49. Manuela: Well I think you know since Trump he preached about you know

50. how Mexicans are rapists and all Hispanics, they're nothing and...I'm

51. American. I was born in America. My mom's white and my dad's Cuban but I

52. still get these racist $\uparrow$ remarks. Like that's always going to happen but I feel

53. like he becomes president, there's going to be a LOT more hate. They're not

54. going to be afraid anymore. I feel like it's not going to be enforced you know.

55. Jorge: It's going to be more open. Since the president can say it, [anybody

56. else can say it. He wants to deport everybody, we can say whatever we want.

57. ((at this point in the conversation, Ethan raises his hand up by his head to

58. signal he wants to say something; as soon as Manuela begins speaking again,

59. he smiles to signal his frustration and begins looking down and pursing his

60. lips))

61. Manuela: [And for the families, their parents are getting deported. A lot of

62. people from Mexico or whatever, they're making money in America, sending

63. it back to their families because they can't afford it there. So they come here

64. to make better, not everyone's a criminal.

65. Emily: [*And also...((to Katherine)) oh sorry. ((chanting)) Ethan! Ethan!*

66. Katherine: [((chanting)) Ethan! Ethan! SAY WHAT YOU”RE GONNA

67. SAY. You got all flustered and stuff, speak.

68. Emily: $\uparrow$ No, what'd you say? 
69. Katherine: You obviously had an opinion. If it was important at the time then

70. you should say it.

Manuela is the first to answer Katherine's question by sharing a way in which she feels personally affected by Trump's narrative against immigrants (lines 49-54). This is the first point in the conversation that a student has shared their beliefs coupled with the personal. Jorge, who identifies as Mexican American, builds off Manuela's point with his own: that the president, as a leader, will influence more people to support more stringent immigration policies (lines 55-56). Manuela also continues her point by alluding to a belief that immigrants should not be stereotyped (lines 61-64). This is actually a strong point for the discussion, but it is overshadowed by Ethan's behavior. As Manuela and Jorge are talking, Ethan is physically getting more excited. He is looking back and forth between Manuela and Jorge with a slight smile on his lips, as if he has the perfect rebuttal, and when Jorge, who is seated next to him, speaks he raises his hand up by his head to signal he wants to say something. However, as soon as Manuela begins speaking again, he smiles to signal his frustration and begins looking down and pursing his lips. This is a moment where Ethan's beliefs about disagreement are highly physicalized. As discussed earlier, Ethan shared with me that often times "I think I'm right, so I'm going to do whatever it takes to prove to you that I'm right until I get solid, hardcore evidence that I'm wrong." At this moment in discussion, it was clear that Ethan strongly felt he could provide a point to the contrary of Manuela and Jorge, but he was also frustrated that, for the first time in a circle discussion, he was going unnoticed.

Further, there is also a dichotomy in this moment between Ethan wanting to prove he's right but also not wanting to hurt his classmates' feelings. As Mr. Stark said, "He 
knows he thinks differently than other kids." However, even though Manuela and Jorge didn't notice Ethan's frustration, Katherine does. In fact, when Emily tries to enter the conversation, Katherine catches her attention and points toward Ethan, thereby silencing Emily in the process (line 65). Once again, Emily performs her deferred identity that is frequently seen when she works in small groups with Katherine. Similarly, Katherine performs her mom identity and pushes Ethan to speak (lines 66-67). This is an interesting moment of tension because Katherine is once more becoming a broker for Ethan as he seeks to prove himself in discussion as well as performing her leader identity of encouraging those silenced to speak. Yet, in doing so she momentarily takes away any agency that Emily would have had as a knowledgeable speaker in that moment, and may be one reason that Emily stayed mostly silent throughout the rest of the conversation, only chiming in to backup Katherine's command for Ethan to speak (line 68). The conversation continues below:

71. Ethan: Did anyone notice when Trump started running for president, he

72. did say all these derogatory things towards Mexicans and other minority

73. races but then he started $\uparrow$ losing in the $\uparrow$ polls and his advisors were like,

74. "You can't go around saying this because you need these people to help you

75. win this job." [He changed the way he spoke and he WON. [[Because he

76. changed the way he $\downarrow$ spoke.

77. Katherine: [Also it's the-

78. Katherine: [[Yeah he changed the way he spoke, not the [way he thought.

79. Manuela: [Yeah he changed the way he spoke and the way he [is to] the

80. actual people who can make him become president. But the people at these 
81. rallies, he's still preaching to them, like these derogatory things.

82. Taylor: Remember it's not popular vote. [Hilary would have won if it was.

83. Ethan: [Exactly so he's saying all this to...but everybody who watches the

84. elect-everybody who watches his debates and watches his rallies, electoral

85. college members watch that too. So they hear $\downarrow$ exactly what he's saying.

86. They don't get a private conversation, he says it to everyone. So if he says

87. something racist to Mexicans ((gestures with his hand toward Manuela)), or

88. blacks or females, everyone hears it. And yes, at the beginning of his elect-

89. the electoral campaign, he did say a lot of mean things to women, Mexicans,

90. blacks, anybody who wasn't white and male, he said racist things to because

91. that's how he felt and he started $\downarrow$ losing. He saw that the way he thought and

92. the way he spoke wasn't going to win him presidency. So he changed it.

93. Katherine: No [he didn't talk about...

94. Kassie: *No strategy though.*

95. Ethan: [He used HIS strategy.

Ethan begins his rebuttal by speaking slowly, as if he is carefully choosing his words. His pro-Trump statement not only enforces his stance as a supporter, but also seeks to get others to reconsider their views. However, Ethan is so entrenched in his own political stance and proving his point that he seems to brush over Manuela's and Jorge's statements about the vitriol of Trump's language, instead choosing to point out that he won because he changed his language. Further, Ethan uses the phrase "did anyone notice" which could be an additional way for him to assert a performed "smart" identity, as if to give information he believes no one else has (lines 71-76). He uses a similar 
phrase, "has anyone ever thought about", later in the discussion. As he speaks, Katherine tries to interject twice, performing her self-described aggressive identity, but also seemingly trying to regain control as a leader (lines 77-78). Intriguingly, Katherine was the one to promote Ethan's right to speak, and yet when she disagrees with what he says she is immediate in trying to share her own opinion, thereby virtually cutting Ethan off in the process. She makes an intriguing counterpoint about thoughts versus words, and Manuela bolsters her statement by revoicing and expanding upon it (lines 79-81). Taylor also steps back into the conversation here to perform her good student identity by sharing factual knowledge about the election, "remember it's not popular vote" (line 82). Her statement seems to serve only to sustain Ethan's beliefs about Trump's win, because he continues seeking to win the disagreement by trying to provide more evidence for his own thinking. At this point, Ethan may feel he does not have a voice, as seen earlier in this chapter in other facets of discussion. While Ethan shared with me that he enjoys arguing as well as being a leader in discussions, his frustration is evident when he is not able to immediately convince his classmates to follow his beliefs. He begins to raise his voice, use physical movement as he is speaking, and falter his words (lines 83-92). Kassie chooses this moment, one of only two, to quietly insert herself into the discussion with the statement "no strategy though" (line 94). As discussed in chapter 4, Kassie considers herself a "sponge" and she often performs this identity in the classroom, soaking up what her classmates are saying rather than speaking out herself. Kassie's seemingly strategic silence up until this point, and soft-spoken statement, made her words that much more jolting. While her statement seems almost incomplete, as if she might have more to say on the topic, none of her classmates encourage her to continue, and 
Ethan immediately silences her by his next statement (line 95). The conversation continues below:

96. Katherine: [((leaned forward in seat, looking at Ethan, pointing towards the

97. ground while articulating words)) Okay and now that he's president that does

98. not stop him from saying anything and doing anything that he wants. [Not

99. only that, but almost the whole House is Republicans. [[HE'S NOT

100. DEALING WITH WHAT OBAMA DEALT WITH. [[[((now pointing

101. directly at Ethan)) Obama was a Democrat, so almost everything that he

102. tried to do got shut down by Republicans. Now he doesn't have that

103. problem.

104. Jorge: [Right, right.

105. Ethan: [[You're right, it is.

106. Ethan: [[[You're right. That is true.

107. Ethan: But there's also amendments in laws where-

108. Katherine: Arrggghhh (noise of frustration) It obviously doesn't matter it

109. still doesn't stop him from saying and thinking about it in the first place.[I'M

110. A TRUMP SUPPORTER BUT THAT'S STILL WRONG.

111. Taylor: ((sing-song)) Sa::lted ((moves hands as if sprinkling salt).

112. ((Ethan and others laugh))

113. Manuela: [It's like—-for him, it's like you wouldn't cuss or do all these

114. things in front of your parents right? But with your friends or with like...I

115. have a hard way of explaining things but, you said the electoral college, they

116. watch that. He shut his mouth, that doesn't mean he doesn't stop feeling 
117. those, after he becomes president maybe he can $\uparrow$ enforce those, because he 118. don't have all those people to shut him down. [You're talking about the past 119. but this is the present.

120. Kassie:[He did it to get into office and once he gets into office he can still 121. express those [things.

At this point in the discussion Katherine, who has tried to interject at multiple points while Ethan is speaking, also begins to physically show her frustration. She leans up in her seat and begins pointing at the ground as if to reinforce each of the words that she is saying. Katherine, like Ethan, seeks to get her point across at all costs. After the circle, she shared with me the following: "I'm a very argumentative person anyway, so if you're going to put me in a circle, basically a circle to argue with someone as to why my point of view is right and yours isn't, I'm [going to] argue and I'm going to make you think I'm right whether I'm right or not." She embodies this statement as she begins to shout at Ethan about Trump's ease of decision making versus Obama's difficulties (lines 96-103). In response, Ethan seems to take a step back from his performed "smart leader" identity and willingly acknowledges that Katherine's point is true, deferring to her knowledge in the process (lines 105-106). This is the only time in any discussion I observed where Ethan openly agreed with another classmate who was making a point in dissent of his own, and therefore briefly rejecting the identity he usually performs. However, when she is done speaking, he immediately picks back up where he left off to state more "evidence" for his own view (line 107). Katherine verbally expresses her frustration (she would often make noises when she felt this way), cuts Ethan off, and yells, "I'm a Trump supporter but that's still wrong" (lines 108-110). 
I characterize this moment based on my understanding of Ethan and Katherine's relationship with one another. While not discussed previously, Ethan and Katherine had dated one another in the $9^{\text {th }}$ grade, and were still very close friends. They would often have side conversations in class, were physical with one another (hugging, playing with each other's hair, etc.), and were vocal about their deep level of friendship. Knowing that, Katherine actually works as a broker for Ethan in this moment. At this point in the conversation, no one has agreed with Ethan, and no one else has even said anything that was pro-Trump. Katherine's statement of supporting Trump is a performance of her "mom" identity in that she is taking care of Ethan in the moment. She may even feel sorry for him. Therefore, while she is simultaneously disagreeing with his statement, she is supporting his person. Katherine's statement serves to bolster Ethan's credibility specifically as a Trump supporter, even if she feels that his view is incorrect. The immediate silence that follows is most likely due to Katherine's raised voice, rather than what she has said. However, Taylor, who seeks to soften moments of tension, cuts the silence with the statement "salted", an equivalent to "you got burned" or "you got told" (line 111). Her statement serves to break the silence (and tension) with laughter, including Ethan's, but this is also a step away from her usual performance of well-liked student, in that Taylor rarely participated in discussion other than to do school. Once this tension seems to dissipate, Kassie chooses to enter the conversation again, revoicing Katherine's statement from earlier (line 120-121. However, her statement goes unnoticed as Manuela speaks at the same time (lines 113-119). In her attempt to further elaborate on the disagreement at hand, she also gives voice to Ethan's statements. Ethan, however, 
seems to yet again reject what Manuela is saying and tries to perform his knowledgeable identity, beginning with the phrase "and has anyone thought about" below:

122. Ethan: And has anyone ever thought about maybe he can't do all of those

123. things ((multiple students speaking)) [he has a right and there is a way but

124. he can't do it all.

125. Katherine: Now he has the right to do it!

126. Jorge: [ I... ((laughing))

127. Manuela: [He's not going to build a wall and make Mexico [pay for it

128. obviously.

129. Katherine: [((puts hand out into circle in stopping motion)) LET HIM

130. SPEAK! LET HIM SPEAK! ((referencing Jorge))

131. Jorge: Okay I want to blow up the world. [You can say that right? You can

132. say it but...

133. ((students talking))

134. Ethan: SHHHHH.

135. ((multiple students state "circle is over"))

136. Emily: Our circle's over. We were arguing!

137. Katherine: Yeah it got really intense those last five minutes.

Jorge, who has been sitting silently but participating through physical reactions, such as shaking his head, smiling, and laughing, tries to speak but gets cut off by Manuela, who is attempting to respond to Ethan's statement (lines 127-128). At this moment, Katherine aggressively puts up her hand in a stopping motion and begins yelling "let him speak", a performed leader/mom identity in which she controls the circle (lines 129-130). But, as 
Jorge begins to make his point (lines 131-132), seemingly performing his philosopher identity through a subtle metaphor, the students begin talking over him about the circle being over (their timer had gone off some minutes ago) despite Ethan's support to try to quiet them down (line 134). Jorge is silenced in the process.

Mr. Stark and I immediately debriefed this discussion after class. He was visibly uncomfortable when voices were raised or when students made inflammatory statements; he elaborates on this below:

Ashley: I noticed today that there were points in the conversation where it looked like you were physically having such a hard time not stepping in.

Mr. Stark: I just want to protect everyone.

Ashley: Is that fair?

Mr. Stark: No you're right. I put my head in my shirt like a turtle.

Ashley: What caused those moments for you and why?

Mr. Stark: I knew somebody was going to be upset by it.

Ashley: Do you think that's the case now that we're done?

Mr. Stark: Yeah, because I know, and that's the danger of a conversation like this, these kids are going to get their ideas out, and they could be hated on because of those ideas, and I don't want that to happen. I didn't want anybody to have lasting animosity based on something else that was said.

The physicality in which Mr. Stark responds to students is not unusual. As explored in chapter 4, Mr. Stark often uses physical response as a literal performance of identity in the classroom. In this case, he was performing a protective identity, similar to when he stopped whole class discussion after Ethan made his comment about welfare. This 
harkens back to a point of tension that is present for Mr. Stark in his classroom: wanting to provide students with a community that has open and dialogic talk, while at the same time feeling he must censor that talk when it becomes too contentious. This dichotomy will be discussed further in chapter 6 . Mr. Stark vacillates between wanting students to promote and accept multiple perspectives, but also wanting to step in when he deems those perspectives as hostile, disruptive, or against the type of narrative he seeks to promote in his classroom. This notion is further complicated by Mr. Stark's belief in his students' own agency, or lack thereof, when coming to their political beliefs systems. He shared, "I think right now they're 15, maybe 16. When I was 15 and 16, I didn't know what I believed. I don't think they necessarily do either. Right now, they're at the point in their lives where they parrot things. They hear this on the news, but I guess it's adults, too." So, Mr. Stark may also be projecting the ways in which he developed his own belief system at their age onto his understanding of his students. This identity marker of his students as "parrots" seems to be at odds with his goals of offering students the chance to talk about their beliefs in a circle discussion where he is not present. Further, the whole notion of a highly contentious circle discussion in which he has no control most likely brings up identity tensions for him of the teacher he wants to be, denoted by giving students this very opportunity, and his figured world of education, in which he believes teacher control, censorship, and narrow content expectations are deemed acceptable.

\section{Considering Critical Moments of Talk}

I chose each of the excerpts above because they comprise critical moments of my time spent in Mr. Stark's classroom as I consider how identity performances shape classroom discussion. In whole class discussion, I provide an example of most "typical" 
discussions I observed, followed by an example of a discussion in which Mr. Stark seems to begin working toward a more dialogic stance on talk. However, as tensions rise and conversation begins to become incendiary, Mr. Stark, who is leading this discussion, quickly shuts it down. Next, I provide two examples of literature circle discussions in which Mr. Stark is both in and out of conversation. In the first, students are participating in a literature circle for the very first time, while in the second, students have completed five literature circle discussions. This second example highlights a point in which students first disagree with one another in a circle discussion, a critical moment in a move toward dialogic discussion. Finally, I provide an example of a political circle discussion in which Mr. Stark is not a participant at all. While the previous examples show students slowly entering into, and exploring, disagreement with one another, this final political circle is almost completely comprised of students only disagreeing with one another. In each of these contexts, students, and Mr. Stark's, identity performances are explored as they negotiate their participation roles in discussion with one another. These identity performances are contextualized in chapter 4 , where I provide brief, not fixed, profiles of both students and teachers.

These critical moments of talk highlight a number of considerations in moving to discussion in chapter 6. First, Mr. Stark and his students perform a number of identities across these discourse contexts; therefore, I will discuss how these identity performances constitute the ways in which they interact with each other, promote themselves in this classroom, and seek to shape, even briefly, who they are within a specific moment. Second, in Mr. Stark's goal to promote dialogic discussion, I will discuss how disagreement pushes or denies multiple perspectives, shapes classroom discussion, and 
promotes or suppresses identity performances. Third, as talk is characterized by moments of disagreement throughout this chapter, I will discuss the teacher's role in relation to student censorship during discussion, specifically considering how both teacher and student navigate critical talk as it relates to classroom discussion and learning. Through a consideration of these points, I aim to contribute to a growing body of literature that promotes the use of classroom discussion as a tool that encourages a consideration of multiple perspectives (Applebee, Langer, Nystrand, and Gamoran, 2003; Sherry, 2014), provides students an opportunity for voice in the classroom (Daniels, 2002; Hall, 2016), and develops controversial talk (Hess \& McAvoy, 2009; Sherry, 2014). 


\section{CHAPTER 6}

\section{DISCUSSION AND CONCLUSION}

I began spending time in Mr. Stark’s classroom at Marville High School during the Spring of 2016. However, my introduction to Mr. Stark occurred before I even began my doctoral work as I was brought on to analyze data from his classroom within a previous study. I contend here, once again, that I come to this study with a researcher lens that is shaped by my own identities, understandings, and experiences. I am a White female who grew up in an upper middle-class family in a small Illinois town. My parents have been married for 34 years. I attended a K-8 school and then a moderately diverse high school. I am a second-generation college student in my family, and I will not be the

first in my family to earn an advanced (terminal) degree. In contrast, Mr. Stark is a White male teacher who is younger than me. His parents divorced when he was in elementary school. He grew up in a working-class family and was the first in his family to earn a college degree. The high school that he attended was in a rural Appalachian county and was characteristically lacking in diversity. Mr. Stark's students have also grown up in a working-class community; however, their community belongs to a large, urban city, and Marville High School is diverse. All of the focal students in this study come from divorced or single parent households and will be first generation college students. I 
highlight these contrasts to acknowledge that this study, and my understandings of the focal teacher and his students, are shaped by these experiences, just as the teacher and focal students' experiences shape the ways in which I observed their identity performances in the classroom. In addition, these contrasts are reasons why I chose to spend time in Mr. Stark's classroom. When I began my study in Mr. Stark's classroom, I was interested in the following questions:

1) How do identity performances shape the ways in which students and their teacher participate in discussion?

2) How do these identity performances mediate the development of critical talk during classroom discussions?

These questions were molded by the uniqueness I feel that Mr. Stark possess as a teacher. They were also shaped by the school and its focal students, including the ways in which students are tracked, the fact that many students at Marville will be first generation college students, and the understanding that these students have minimal experience with discussion as a classroom tool. In this chapter I will discuss how identity performances shape each of these components of classroom talk, just as in the broader sense I believe that identity performances are shaping the culture of this classroom in relation to discussion. Further, I will discuss the ways in which I hope to contribute to a growing body of literature that promotes classroom discussion as a tool that can engage students in multiple perspectives, provide students an opportunity for voice in the classroom, and develop students' controversial talk. I will also expand on the ways in which classroom discussion can limit each of these outcomes, as is necessary when considering the complicated nature of discourse. 


\section{Identity Performances}

In order to better understand how Mr. Stark and his students were performing identities during classroom discourse, I analyzed talk in three different contexts: whole class discussion, literature circle discussion, and political circle discussion. I chose these contexts for a number of reasons. First, each of these comprise contexts that I observed that were different from one another in terms of the ways in which talk occurred. Second, Mr. Stark's role in each of these contexts varied: in whole class discussion, he was leading talk; in literature circle discussions, he was both a participant and nonparticipant; and in the political circle discussion he was a nonparticipant, where he did not intervene in talk in any way. Finally, talk looked different in each of these contexts, where students were vacillating from I-R-E patterns to budding dialogism to controversial disagreement. These identity performances shape the ways in which discourse occurred in Mr. Stark's classroom, and so I begin with a brief overview of these performances before discussing how they contribute to the discussion constructs of multiple performances, voice, and controversial talk.

As Mr. Stark and his students participated in discussion, they performed identities that sought to agentically convey, through talk, who they are and what they believe in that particular moment (Holland et al., 2003; Moore \& Cunningham, 2006). Mr. Stark’s participation level was very different in each of these discussion contexts, and therefore so were his identity performances. In chapter 4, I contextually profiled Mr. Stark and the focal students, analyzing how they spoke about who they are, who they want to be, and how they believe (or want) others to perceive them. I then explored the ways in which these identities were performed through discourse. As both students and teacher 
participated in discourse, they performed identities that both reinforced and challenged their understandings of themselves. Ethan and Katherine, who both consider themselves leaders in the classroom, were almost always participating as leaders in discussion. Ethan would often perform his "smartest kid in the class" identity, seeking to share knowledge that he thought was privileged; this identity performance sometimes trumped his goal of being discussion leader. However, Ethan's performed identity was also silenced in a number of places as he shared knowledge that was political or argumentative. Katherine's performed leadership identity often meant she would take on her "mom" role, asserting her "aggressive" identity to shape discussion. She also performed her "mom" identity to become a broker (Perry, 2009) for other students as they talked, namely Ethan. Additionally, Jorge performed a leadership identity in discussion; however, this seemed to be a secondary intention for him, as he often would step out of this role to subtly challenge any other leaders, performing his identity of working against the status quo. $\mathrm{He}$ also attempted to perform his "philosopher" identity during circle discussion, but was often silenced.

Across discussion contexts, Taylor performed her "good student" identity by modeling teacher talk and "doing school". Emily was the most unique participant in discussion. She both performed and rejected her identity of "not the brightest crayon", vacillating between asserting herself through talk or hanging back as she would during table conversation with her friends. Finally, Mr. Stark's identity performances also varied across contexts. During whole class discussion, he took on the role of teacher as talk leader, whereby performing an identity that seemed to align with his figured world of education. He also frequently shut down talk when tensions would arise, which speaks to 
his performed identity of protector of his students. During literature circles, Mr. Stark was both in and out of the conversation, performing his "figured world of education" identity but also seeking to move conversation to a more dialogic form, something that he shared was important to him in his classroom. While Mr. Stark did not speak during the political discussion, his still performed his identity through physical movements- - this was especially the case when talk got argumentative, a tension for him in his move toward a more dialogic classroom. Each of these identity performances through discourse shaped the ways in which talk was occurring during any given discussion context. Further, these identity performances shaped the ways in which both students and teacher developed critical (political talk) and disagreement, engaged in perspective taking, and took up or were denied voice and agency in the classroom, which I will consider below.

\section{Political Talk and Disagreement}

The most salient findings of this study came through analyzing the ways in which political talk and disagreement developed within this classroom. Across each of the discussion contexts (whole class, literature circle, and political circle), both students and Mr. Stark were grappling with an exploration of how disagreement played a role in classroom discussion. Mr. Stark's performed identities shaped the ways in which disagreement did or did not occur as he sought to provide students with the opportunity to move toward a more dialogic form of discussion. These performed identity tensions between the teacher Mr. Stark wants to be and his figured world of education dictated how conversation developed. For example, in whole class discussion, Mr. Stark opened up conversation about politics, namely due to the recent presidential election, and was enacting his performed "teacher I want to be" identity, providing students with space to 
talk about highly personal and charged topics. Further, he shared his own political beliefs, something that is often contested in classroom spaces (Hess \& McAvoy, 2015). However, as Ethan began to make statements that did not align with Mr. Stark's goals of the conversation (Dong, 2008), and were either controversial or caused perceived tension, Mr. Stark's performed identity shifted into his figured world of education (and protector of students) causing him to immediately shut down conversation (Fecho et. al., 2005). This was one of the first moments of political polarization I observed in Mr. Stark's classroom-Ethan's pro-Trump views were most certainly in the minority within this classroom, and he was quite vocal about espousing them. Mr. Stark's response spoke to his own reticence for students to foray into discussion that might get uncomfortable (Zhang et al., 2016). As Hess and McAvoy point out, "Some teachers avoid topics that may be particularly heated in the community, while other educators decide to avoid political controversy altogether" (p. 8). Mr. Stark did not go into this discussion with the intention of avoiding the topic; quite the opposite, he broached the subject with the intent to allay fears of his students, many of whom felt personally victimized by recent rhetoric in the country. However, when he anticipated forthcoming discomfort from other students based on Ethan's statement about those on welfare, he took away Ethan's power as a speaker and silenced in the process (Hinchman \& Young, 2001). This is a common reaction as Sherry (2014) notes that "the nature of these positions, which sometimes include intolerant, ill-informed, and potentially offensive ideas, might seem to call for more direct intervention on the part of the teacher" (p. 156). As discussed previously, Mr. Stark tried to rectify this silencing by talking to Ethan afterward, but Ethan still shared that he was reticent to speak in the later circle discussion because he did not want to hurt 
anyone's feelings (Rogers, 2002). This occurrence brings to light the complicated nature of critical (political talk) in the classroom. While Mr. Stark set out to allow students to talk about topics they disagreed on, and topics that were already polarized based on the state of the nation and the views of his students, he also may have bred more distrust between himself and Ethan in order to protect other students from Ethan's controversial statements. This example highlights one of Hess and McAvoy's (2015) key findings: "political polarization affects what teachers do and are able to do in their classrooms" ( $\mathrm{p}$. 81). At a point in which polarization is at an all-time high, Mr. Stark's performed identity during discussion vacillated between the teacher he wants to be and his figured world of education. These performed identities are polarized in and of themselves as Mr. Stark constructs his own worldview of his classroom and the ways in which discussion takes place within it. Further, Mr. Stark's shutting down of conversation in this moment aligns with previous studies that have shown that teachers are reticent to introduce discussion around topics that may feel risky to them (Dong, 2008; Hess \& McAvoy, 2009; Zhang et al., 2016).

Further, as students began to participate in literature circle discussion (and discussion for the very first time), they explored what disagreement might look like in this context, as was the case with their talk around Lord of the Flies (Golding, 1954). The talk analyzed in the previous chapter was the first time that students disagreed with one another, and further the first time students vocalized their delight in that disagreement. While Ethan performed his knowledgeable identity with his Spartans example, Manuela chose to push back on his statement by disagreeing with what he said. She did this multiple times, however neither she nor Ethan seemed to concede the others' points, 
which researchers note is a common occurrence when students are first beginning to learn how to disagree with one another during discussion (Bickmore \& Parker, 2014; Hall, 2016). However, it's also important to note that this might be productive tension as students learn to share a talk space with one another (Hall, 2016). Emily also briefly entered at this point in conversation, seemingly as a broker (Perry, 2009) between Manuela and Ethan's disparaging statements. However, what's most interesting about this section of talk is that Ethan doesn't seem to view Manuela's statements as explicitly disagreeable, and got excited only at the end when another student uses the phrase "I disagree with you because" before inserting her viewpoint. This portion of discussion illustrates the importance of students learning what constructive disagreement with one another looks like as they move toward dialogically oriented discussion (Bickmore \& Parker, 2014; Sherry, 2014). While disagreement has often been shunned by teachers as a negative outcome in the classroom, as students learn to both agree and disagree with one another, they are also learning how to construct shared meanings and interpretations about the world around them (Sherry, 2014; Sutherland, 2007). While the dialogue above is most certainly moving students in the direction of more dialogically oriented talk, it is clear that a better understanding of talk moves, and of what it means to be a participant within this type of discussion, may have led to students seeing each other's disagreements, uptake of conceding points, and construction of broader worldviews (Carbone, 2010; Glenn \& Ginsberg, 2016; Malloy et al., 2015).

Finally, as students moved into the political circle discussion, in which Mr. Stark was not a participant, their conversation about highly personal issues, and fears about the state of the nation, quickly bred disagreement. Whereas disagreement slowly built over 
time during the literature circle discussions, students' propinquity with political issues, some of which they were living in their daily lives, caused disagreement to appear immediately as they talked about a broad range of contentious topics (Bickmore \& Parker, 2014). This passion seemed to exaggerate and heighten students' performed identities as they sought to "prove" their beliefs to others (Bickmore \& Parker, 2014; Hall, 2016). Katherine performed her mom identity to give Ethan voice in the conversation, but she also performed her aggressive identity to argue with Ethan as he made statements to exonerate President Trump. Ethan stayed exceptionally quiet at the beginning of the conversation, to the point that it became physically noticeable he wanted to step in; this could have been a performed identity in and of itself as Ethan proved his smart kid identity through physical response that characterized his frustration and dismissal. However, when Katherine brought him into the conversation, he took up a performed leadership identity as he sought to combat (and did not seem to consider) others' opinions. Jorge performed a leadership identity seeking to promote others' ideas or push back against them. Yet, he was silenced when he began to philosophize and try to metaphorically respond to the question (Hall, 2016). Emily, who gained agency as a speaker during literature circle discussions, seemed to go back to her performed "not the brightest crayon" identity, choosing only to speak when endorsing others' statements (Hall, 2016). Each of these performances shaped the ways in which disagreement developed during the political circle discussion.

As much research has shown, the development of critical talk and disagreement in this classroom was not without its challenges for both students and teacher (Bickmore \& Parker, 2014; Dong, 2008; Sherry, 2014; Zhang et al., 2016). Further, political talk, as a 
subset of critical talk was still developing in this classroom as students learned how to promote competing viewpoints, listen to others' stances, and speak about impassioned topics (Hess \& McAvoy, 2009; Rogers, 2002; Sherry, 2014).

\section{Perspective Taking}

Mr. Stark's goal when using discussion in his classroom was to encourage multiple perspectives. In fact, he spoke to me about perspective taking almost every time I interviewed him, stating that it was important for students to learn that theirs is not the only perspective in the world. Many researchers note that one of the ways that dialogic discussion functions in the classroom is to encourage multiple perspectives (Carbone, 2010; Dong, 2008; Glenn \& Ginsburg, 2016; Gritter, 2012). Yet, this encouragement can be complicated by a number of factors, including the ways in which participants perform identities through talk. For example, during whole class discussion centered on the political climate of the country, Mr. Stark tried to open up conversation so that he might address students' fears and concerns about the state of the nation. However, when Ethan made statements that could have been perceived as controversial, Mr. Stark first silenced him, despite other students' attempts to give him voice, and then when his comments continued, immediately stopped the conversation. In this moment, Ethan's perspective was not one that was encouraged and he was denied voice because Mr. Stark was concerned he might hurt another student's feelings and therefore invoked a power differential to end talk (Hinchman \& Young, 2001). However, it's also important to note that Ethan's perspective was not the status quo and therefore, in this moment Ethan performed what Sutherland (2007) refers to as an identity of resistance. As a Trump supporter, Ethan was definitely in the minority within the class, and most certainly not 
aligned with Mr. Stark, who voted for an independent candidate. By denying Ethan's comments, multiple perspectives weren't fostered but rather constrained. Later, Mr. Stark recognized this and attempted to talk privately with Ethan about it, but this still made Ethan reticent to participate in the political circle discussion. He knew that his perspective was not a popular one, and he had also been silenced by the teacher in front of his peers, which may have made him feel that his perspective, while in the minority, wasn't valued at all. In addition, students were also responsible for denying multiple perspectives during the circle discussions. While oftentimes students would give their own viewpoints on topics, these viewpoints were never pushed further or able to gain traction through uptake, which is the opposite of what Hall (2016) described as sharing talk space. In many cases, students would simply respond evaluatively before moving on to insert their own viewpoint. An example of this occurred when Ethan audibly sighed during the literature circle discussion, merely waiting to perform his knowledgeable identity, and inserted a comment that does not seem to follow with the conversation at hand. At this point, while Ethan may not have been denying multiple perspective taking, he was certainly not working to develop it. In this moment, Ethan sought to dominate the discussion by building on his own cultural model of knowledge as leader (Thein, 2009).

On the other hand, when Mr. Stark seemed to encourage talk to move beyond a standard I-R-E pattern toward dialogism, students began to take on the role of encouraging multiple perspectives themselves (Zhang et al., 2016). During literature circle discussion, Katherine frequently performed her "mom" identity, and this was often to encourage others to join the conversation or continue their talking points. While this was an embodiment of Katherine's identity, it also served to promote perspective taking 
as students may have felt empowered to speak or continue to speak. The most notable moment of this may have occurred when Ethan wanted to speak in the political discussion but did not feel recognized to do so. Katherine pushed on Ethan to speak, even getting Emily to join in, until he shared his perspective. This talk move was powerful because Ethan was, at this point, already reticent to speak in terms of the topic. Ethan shared his beliefs and, while disagreement ensued, was able to voice a perspective that may have gone unstated. Jorge also frequently encouraged multiple perspectives through his performed identity of disturbing the status quo, namely because Jorge believes there are many ways to look at something. While Jorge was not always successful, such as the end of the political conversation when he attempted to perform his philosophical identity to counter a point, he often would encourage other students' statements to promote alternative perspectives. In these moments, Jorge was actively working against Pace's (2006) notion of adopting dominant discourses in discussion. He performed this identity a number of times during the political circle discussion. In addition, while Taylor often performed her good student identity, there were a number of these moments that seemed to develop perspective taking, such as her role during whole class discussion of reminding Ethan to consider where his sources came from.

During the early literature circle discussion, Mr. Stark also encouraged students to share their perspectives. When he pushed back on Katherine to answer Steven's question, he then built upon her statement using an open-ended question to encourage discussion. This modeling of talk may be indicative of Mr. Stark's goal of moving discussion to a more dialogic form in his classroom, and one that is well noted in the literature for its successes (Sherry, 2014) and its challenges (Dong, 2008). Further, during the later 
literature discussion, the students seem to take up this talk move (Sherry, 2014) as they push back on Ethan's comparison of the LOTF storm scene and his Spartans example. Manuela pushed back on Ethan's perspective while Taylor, as stated above, built on his thinking by first agreeing and then inserting her own, somewhat aligned perspective. These emergent talk moves were characteristic of a more dialogic form of discussion and showed students moving away from their previous circle discussion pattern of question, answer, evaluation, repeat (Rogers, 2002).

\section{Power, Agency, And Voice}

Finally, I contend that the use of discussion in Mr. Stark's classroom heavily shaped the ways in which both students and teacher wielded power, developed voice and gained agency through discourse. The tensions between the identity performances of the teacher Mr. Stark wants to be and his figured world of education were prevalent throughout these moments of discussion, and seemed to shape the ways in which Mr. Stark gained agency and wielded power through the use of this technique. One of Mr. Stark's goals for his classroom was that students would come to understand, and appreciate, that their perspective was not the only one in the world. He hoped that this would shape the ways in which they would talk and interact with others as they became adults. Mr. Stark's enactment of discussion in the classroom spoke to this process as he sought to give students the space and place to have a voice where they otherwise might not, and to have agency as speakers within his classroom. However, his performed identity tensions served to both develop and restrain both voice and agency across the different discussion contexts (Hartman, 2016; Sloan, 2006). For example, in whole class discussion, Mr. Stark opened up conversation with the intention of giving students the 
opportunity to voice their fears and concerns about the state of the election in the U.S. Yet, when students tried to voice these, especially Ethan, Mr. Stark silenced his voicing for fear of repercussions.

In literature circle discussions, Mr. Stark performed an identity that encouraged multiple perspectives by pushing back on Katherine to answer Steven's question, whereby providing space for her voice to be heard where it might otherwise have been looked over. Finally, in the political circle discussion, Mr. Stark chose to not participate at all in hopes that students would have a free space, devoid of his input, to voice their opinions on highly personal topics. Yet, for any student that observed Mr. Stark's physical response to the conversation, his performed figured world of education identity was apparent as he cringed and, at one point, pulled his shirt up over his head "like a turtle". Through these performed identity tensions, Mr. Stark seemed to move from one extreme to the other as he sought to provide students with the space and place to voice their perspectives. These vacillations are well-noted in the literature as teachers wrestle with their own power and management of critical talk in the classrooms and their ongoing identity work (Bickmore \& Parker, 2014; Hinchman \& Young, 2001; Newell, Tallman, \& Letcher, 2009; Sloan, 2006).

Yet, Mr. Stark did seem to gain agency as a teacher in the classroom through his promotion of discussion. He engaged in risk taking by allowing his students to engage in political talk not once but twice, despite his reservations and performed figured world of education identity (Hartman, 2016). These results may not have been what he hoped for: during whole class discussion, he regretted shutting down Ethan's perspective and during the political circle discussion he was concerned that because students were "yelling" 
someone might have gotten their feelings hurt or may stay upset for quite some time. However, I contend that these were agentic moments for Mr. Stark because, while vacillating between his own performed identity tensions, he provided students with a timely and authentic opportunity to discuss personal and concerning topics that would directly affect all of their futures (Clarke, 2006; Thein, 2009). Further, he made it clear that bringing political discussion into his classroom was something that he was uncomfortable with; this is not to say that agency always comes with discomfort, but that agentic moments may sometimes be borne out of situations that breed the unfamiliar (Hess \& McAvoy, 2009).

Each of these discussion contexts provided space for students to develop voice (or be silenced) and gain (or lose) agency. As mentioned previously, during whole class discussion Ethan tried to voice his views on the election by performing his knowledgeable identity. However, when he made controversial statements (such as his comment about welfare), Mr. Stark silenced his voice, even when other students sought to bolster his agency by brokering for him (Hinchman \& Young, 2001). Because of this silencing, Ethan was reticent to speak in future political talks, and took quite some time to voice his opinions during the political circle discussion. In spite of this, when Katherine and Emily encouraged Ethan to share during the political circle, he gained agency through their encouragement and voiced his opinions, but did not seem to contend others' in the process (Glenn \& Ginsberg, 2016; Pace, 2006). In this moment Ethan had voice and performed his leader identity, as he seemed to in both circle discussions, but did not use that voice or leadership to encourage or consider others' perspectives. In this case, his voice may have been limiting others' moments to develop voice as well (Hall, 
2016). Katherine also performed a leadership identity in circle discussions, but she would sometimes use her voice and position to promote others' talk, as she did when brokering for Ethan during whole class discussion. She did the same when performing her mom identity in the political circle discussion, encouraging Ethan to talk when he was reticent. However, Katherine's aggressive identity also came out when she was a leader in discussions, which may have caused her to silence other voices in the process (Hall, 2016). The most salient example of this is when she is encouraging Ethan to talk. She simultaneously seeks to give Ethan voice while denying Emily the same opportunity, silencing her when she seeks to add to the discussion (Hinchman \& Young, 2001).

Emily, most interestingly, may have gained the most agency during the literature circle discussion, but that agency was tempered by the political nature of talk and Katherine silencing her above. As Emily shared with me, she considers herself "not the brightest crayon" and often hangs back during small table and whole class discussion, letting those more dominant (like Katherine) lead (see chapter 4) (Rogers, 2002). However, during the literature circle discussion, Emily frequently took on more of a leadership role, answering her classmates' questions and providing her own thought provoking statements. Further, where Emily would normally hang back in conversation, she was routinely one of the first to speak during literature circle discussions. These moments for Emily are aligned with current literature that suggests discussion can have a positive impact on student voice (Nachowitz, 2015; Malloy et al., 2015). Conversely, Emily's agentic moments were complicated during the political circle discussion. Emily's moments of hanging back were often dictated by her unwillingness to "rock the boat" and, like past research notes she may have been hesitant to voice a response that did not 
reinforce the dominant discourse of the discussion (Pace, 2006; Rogers, 2002). Because the political circle led to much disagreement over impassioned views, she may have hung back based solely on the subject matter and the power that was tied to competing performed leader identities (Hinchman \& Young, 2001). While Emily did insert herself into conversation a few times at the beginning, even making an interesting point connecting texting to Clinton's email scandal, and thereby performing an identity of resistance (Sutherland, 2007) by challenging the dominant discourse, when disagreement heightened, she became much quieter. Unfortunately, her lack of voice was only intensified when Katherine silenced her, to allow Ethan to speak, at her first attempt to enter herself into the discussion, which seems to fit the cultural model of the girls' friendship and table relationship (Thein, 2009). From that point on, her agency seemed stifled and her voice suppressed. It was at this point that she reverted back to her performed not the brightest crayon identity that she shared she embodies with Katherine and her other group members. It may be important to note here that Jorge was also silenced by his classmates at the end of the political circle discussion, but this may have been largely due to structure. The students' timer had gone off, signaling an end to their circle, and they had spoken past it for a few minutes. As Jorge began to speak, students were restless and looking to Mr. Stark for guidance on whether they should continue. For this reason, it's hard to say whether this was a stifled agentic moment for Jorge, or simply bad timing.

\section{Future Directions for Research}

This research suggests that providing students with a space to take up critical (in this case political) talk is crucial in order for students to attempt to engage in perspective 
taking, collaborative disagreement, and voiced, agentic moments of talk (Bickmore \& Parker, 2014; Carbone, 2010; Glenn \& Ginsberg, 2016; Nachowitz, 2015). As Beach, Thein, and Parks (2008) assert "In an increasingly diverse society, adolescents need not only to acquire tolerance for diverse perspectives but also to learn to critique the institutional forces perpetuating racism, class inequality, and sexism that work against openness to diversity" (p. 28). However, it also contends that there are a number of complications in doing so, including how this type of discussion develops, whether talk can move beyond non-collaboration into a co-construction of views, and who gets heard and when. I contend that both teachers and students performed identities that shaped discussion across contexts in this classroom, however, the conversations around politics were unplanned, reactive, and occurred only within one week of each other. Future research in this area might consider the ways in which both teachers and students work to develop critical discussion in the classroom proactively and over a longer period of time, paying special attention to how performed identities shape this development. Further, future research should consider how political discussion develops outside of the social studies classroom, which is well researched by Hess and McAvoy (2015) as teachers across other disciplines take part in this type work.

Another implication of this research is that disagreement, especially during political discussion, did not always breed a space for multiple perspectives to be heard, but rather had students participating in non-collaborative disagreement as they sought to prove their views to one another, resulting in the silencing of voices and unheard perspectives (Hall, 2016; Rogers, 2002). Future research may explore how classrooms move disagreement beyond non-collaboration into a space where students can use 
conflicting perspectives to co-construct views with one another, paying special attention to the ways in which both students and teacher develop listening skills.

In this research, there were moments in which students were able to gain voice and agency through discussion, these were often stifled by a perpetuation of leader identity performances or gained only by those that performed identities in which that might naturally occur (Hall, 2016; Hinchman \& Young, 2001). Future research might observe how the promotion of unheard perspectives occurs in the classroom, paying special attention to those moments when students discard their performed leadership identities to "give the floor" to someone else. Additionally, future research may also explore the ways in which teachers support the development of voice and agency in their classrooms by providing other spaces of discussion (small group, online) for students to talk about their fears and concerns, a timely and important area of discussion with the state of our nation.

A final area of research that deserves further study is a better understanding of the identity tensions that teachers face in their daily practices, including how those tensions arise, how teachers respond to those tensions, and how those tensions are managed through discourse (Fecho et al., 2005; Sloan, 2006; Zhang et al., 2016).While this study looked at how one teacher navigates these tensions, future research may examine how and when other teachers feel competing discourses as they vacillate between the teacher they want to be in the classroom and the teacher they believe belongs in the world of education. Moreover, while this study focuses on political talk, future studies may examine how teachers navigate these identity tensions to overcome their fears and concerns when talk gets risky in their classrooms in response to other critical topics 
including racism, stereotypes, and gender biases. Finally, future studies could research how teachers' identity tensions shape classroom practices beyond discussion.

\section{Implications for Classroom Teaching}

This study suggests that providing students with a classroom space to discuss critical topics, even when they foster disagreement or contentious viewpoints, is necessary as students learn to engage in perspective taking and a broadening of worldviews. Discussion that promotes an opportunity for students to talk about critical topics may promote an increase of student voice across the classroom and an increased sense of agency. To that end, the following instructional strategies may assist teachers as they navigate through the risk taking involved in this type of talk.

\section{Modeling of Talk}

Sherry (2014) writes about the importance of teachers' modeling talk as a strategy to engage in dialogic discussion. However, the modeling of talk strategies is often attached specifically to circle discussions, sometimes called Socratic seminars, rather than classroom discourse in the broadest sense. While many teachers create norms to guide their classroom management, norms specifically for talk seem to be developed less commonly. By applying talk strategies and the modeling of talk to daily discourse practices across contexts, and making those strategies transparent, teachers can encourage dialogic discussion in a more universal fashion.

\section{Encouraging Silenced or Alternative Perspectives}

Bickmore and Parker (2015) write about the importance of teacher encouragement for students who have been previously silenced or bring perspectives into the classroom that are not dominant. First, teachers' modeling of talk moves may include strategies that 
encourage perspective taking, such as uptake (Applebee et al.,2003) which may lead to students ensuring that all voices are heard during discussion. Providing students with the opportunity to examine silenced and alternative perspectives beyond the classroom, in relation to critical topics, may cause them to become more critically aware of, and question, the world around them. Further, Wortham asserts that students' and teachers' identities are positioned by political texts. Providing students with the additional opportunity to critically question political topics may give them agency as they become voting members of a democratic society. As Hess and McAvoy (2015) state, "Being informed and concerned about particular issues and political outcomes is an important starting point for engagement, and teachers in the political classroom ought to encourage students to care about the outcome of current issues" (p. 79).

\section{Allowing Students to Take Ownership of Discussion}

Students should be given the opportunity to take ownership of classroom discussion, whereby the teacher becomes a facilitator, rather than a leader of this type of work. Dong (2008) notes that when teachers are too focused on their own agenda, or for students to "get it right" when it comes to discussion, they end up silencing voices and denying perspectives in the process. By giving students the floor during discussion and shifting from a preconceived agenda, students can develop agency as facilitators of the process. Further, Daniels (2002) notes that students should be partners in developing the ways in which their discussion performances will be assessed in the classroom.

\section{Preparing and Allowing Students to Engage in Political Talk and Disagreement}

Hess and McAvoy's (2014) research notes the importance of preparing students to engage in political talk and disagreement. They write, "Mastering the ability to talk 
across political and ideological differences helps create an informed citizenry--an essential component of a democratic society--by teaching students to weigh evidence, consider competing views, form an opinion, articulate that opinion, and respond to those who disagree" (p. 5). As students learn to engage in political talk, talk modeling, encouragement of perspectives (especially those that are alternative to the status quo), and an increase in student agency through ownership of discussion are especially imperative for students to engage in the components of a democratic society listed above. By taking up strategies to encourage student participation in political talk, teachers can initiate the first step in young people viewing one another as political equals.

\section{Considering Identities Performances in the Classroom}

Finally, teachers should take into consideration the many identities being performed in their classrooms by both students and themselves in relation to classroom learning. When developing a classroom in which dialogic discussion is privileged, teachers must consider the ways in which talk is shaped by the identities that populate it. Moore and Cunningham (2006) contend that authentic dialogues occur when "people do not analyze others' specific isolated qualities; they accept each other's entire selves. They have high regard for whatever they and others have to offer. They share a sense of caring, commitment, and responsibility. When the voices contributing to inner conversations are dialogic, they are respected and consulted diligently" (p. 137). Becoming more cognizant of the ways in which people are shaped by the many different qualities they inhabit, which then in turn shape the ways in which participants participate in and respond to others during classroom discussion, may lead to a more holistic understanding of how dialogic discussion develops over time. 


\section{Limitations}

Below, I list several limitations for this study. As with any research, this study has a number of limitations, but I highlight the most pertinent below.

1. This qualitative research study is grounded in the unique context of the school, the classroom, and the experiences of the participants. I see the purpose of this qualitative research study as seeking to build on current research through an ethnographic lens by immersing myself into the locally bound experiences of these participants within this classroom. Therefore, this research is about these participants' unique experiences and performed identities within this specific classroom, and does not speak to any large-scale generalizations about performed identities across classrooms.

2. I was only able to immerse myself in this classroom for approximately 4 months. Although, I had conducted previous research with Mr. Stark as well. However, I did not get to spend any type of extended time within this classroom or beyond it. Further, I was not able to observe the focal students or Mr. Stark in any other setting but this classroom. Any information about these students' or Mr. Stark's lived experiences beyond the classroom came from my interviews with them. The data collected were used to develop a limited, local perspective of my time spent with these students and Mr. Stark. It does not presuppose that these findings are summative of Mr. Stark and his students' identities or lived experiences.

3. This study used a primary lens of identity performances to better understand how discussion is shaped by, and does shape, classroom culture. However, this study did not take into account other factors that may shape discussion and classroom 
culture, including gender, race, or academic histories. Studies that foreground how each of these components may also shape discussion are warranted but not in the purview of this study.

4. During this study, I was only privy to discussions that occurred while I was present in the classroom. Therefore, I do not seek to make generalizations about the nature of Mr. Stark's classroom discussion in general, but rather only make assertions based on my observations. Further, it should be noted that classroom discussion is constantly evolving, as are the identities that participants perform during discussion, and so neither should be looked at as stagnant or fixed. I also contend that the political discussion was borne out of highly unique circumstances, which may have made this conversation that much less generalizable.

5. Finally, I reiterate that I was a White female observing in a White male's classroom with students from diverse backgrounds. Further, these students were from socioeconomic stances that were exceptionally different from any that I have known growing up in an upper middle-class family. While I developed a relationship with Mr. Stark, he and his students may have felt the need to perform identities or respond during interviews in certain ways due to my role as a White woman and researcher from a large university.

\section{Final Thoughts}

Spending time at Marville High School, and particularly in Mr. Stark's classroom, helped me to understand that classroom discussion isn't something that just happens, but rather is an intricate web of discourse that is continually shaped by the participants who 
inhabit it. Further, as I considered the ways in which performed identities were at play as students and their teacher learned both through and in discussion, I realized the nuances that must be considered when cultivating a dialogically oriented classroom. In this classroom, discussion was both planned and unplanned, two extremes that must be considered as teachers take up these practices in an effort to provide students with this learning opportunity. As someone who was, and is, indoctrinated into a belief that discussion is instrumental for classroom learning, a consideration of the tensions that $\mathrm{Mr}$. Stark faced, and the ways in which students were positioned, silenced, emboldened, and agentically shaped has caused me to reconsider how I will invite future teachers into this practice.

To harken back to the quotes at the beginning of this study, I contend that this is my interpretation of Mr. Stark and his students, but one of many truths. This interpretation is shaped by my own discourse practices, and while it is my truth, it may not be Mr. Stark's or his students' truth. However, I believe that is the beauty of this qualitative work, and why it speaks back to the research questions I sought to answer in this study. In believing that dialogic discussion is beginning to form in Mr. Stark's classroom, I then also believe that there are many people, interpretations, and truths shaping that discussion, with a consideration for them all. For, as Bakhtin writes, "Truth is not born nor is it to be found inside the head of an individual person, it is born between people collectively searching for truth, in the process of their dialogic interaction" (1984, p. 110).

Further, I performed my own identities throughout my time in Mr. Stark's classroom, and these identities were shaped by the ways in which I participated in 
discourse with Mr. Stark and his students. My time in Mr. Stark's classroom allowed me to take up the nuanced discourse of researcher, but this discourse was constantly at tension with others as I negotiated who I was in that space. It was through the discourse of research that I took up my own performed identities within this classroom, and these performed identities were in turn shaped by the many performed identities of the participants within it.

When I left Mr. Stark's classroom, I asked his students to write down for me what they thought other teachers might learn from him. I was curious as to what they would say. Some of their responses were that teachers could learn:

- to be more open with their students

- it's good to be silly sometimes

- to influence people to share their feelings on what they believe

- to understand that each student is different and learns different

- to be patient and understand students who aren't really outspoken

I firmly believe that each of these points above harkens back to the work done here.

However, it also speaks to the broader implications of the work that Mr. Stark is doing in his classroom.

The last time I interviewed Mr. Stark, he shared with me a Maya Angelou quote that is the mantra he teaches by. I end with it below: "If you are always trying to be normal, you will never know how amazing you can be." 


\section{REFERENCES}

Agee, J. (2006). What kind of teacher will I be? Creating spaces for beginning teachers' imagined roles. English Education, 38(3), 194-219.

Alexie, S. (2009). Absolute true diary of a part-time Indian. New York, NY: Little, Brown Books.

Alsup, J. (2005). Teacher identity discourses: Negotiating personal and professional spaces. New York, NY: Routledge.

Anderson, L.H. (1999). Speak. New York, NY: Square Fish.

Applebee, A.N., Langer, J.A., Nystrand, M., \& Gamoran, A. (2003). Discussion-based approaches to developing understanding: Classroom instruction and student performance in middle and high school English. American Educational Research Journal, 40(3), 685-730.

Bakhtin, M.M. (1982). The dialogic imagination: Four essays. Austin: University of Texas.

Bakhtin, M.M. (1986). Speech genres and other late essays. Austin: University of Texas.

Bean, T.W., \& Moni, K. (2003). Developing students' critical literacy: Exploring identity construction in young adult fiction. Journal of Adolescent \& Adult Literacy, 46(8), 638-648.

Bickmore, K., \& Parker, C. (2014). Constructive conflict talk in classrooms: Divergent approaches to addressing divergent perspectives. Theory \& Research in Social 
Education, 42(3), 291-335.

Boyd, M.P. \& Markarian, W.C. (2015). Dialogic teaching and dialogic stance: Moving beyond interaction form. Research in the Teaching of English, 49(3), 272-296.

Cain, S. \& Laird, M. (2011). The fundamental 5: The formula for quality instruction. North Charleston, SC: CreateSpace Independent.

Carbone, P.M. (2010). Using commonplace books to help students develop multiple perspectives. English Journal, 99(6), 63-69.

Cazden, C.B., \& Beck, S.W. (2003). Classroom discourse. In A.C. Graesser, M.A. Grensbacher, \& S.R. Goldman, (Eds.). The handbook of discourse processes (165197). Mahwah, NJ: Erhlbaum.

Chisholm, J.S. \& Loretto A.J. (2016). Tensioning interpretive authority during dialogic discussions of literature. L1- Educational Studies in Language and Literature, 16, $1-32$.

Chisholm, J.S., \& Olinger, A.R. (2017). "She's definitely the artist one": How learner identities mediate multimodal composing. Research in the Teaching of English, 52(2), 122-155.

Chisholm, J.S. \& Shelton, A.L. (2016). Backchanneling technology: Transforming students' participation during discussions of If I Grow Up. The ALAN Review, 43(3), 22-34.

Clarke, L. (2006). Power through voicing others: Girls' positioning of boys in literature circle discussions. Journal of Literacy Research, 38(1), 53-79. 
Collins, S. (2008). The hunger games. New York, NY: Scholastic.

Compton-Lilly, C. (2006). Identity, childhood culture, and literacy learning: A case study. Journal of Early Childhood Literacy, 6(1), 57-76.

Cook, J.S. (2009). "Coming into my own as a teacher": Identity, disequilibrium, and the first year of teaching. New Educator, 5(4), 274-292.

Cisneros, S. (1984). The House on Mango Street. New York, NY: Vintage.

Daniels, H. (2002). Literature circles: Voice and choice in book clubs and reading groups. Portland, Maine: Stenhouse.

Dong, Y.R. (2008). Productive tensions: Student teachers' handling of sociocognitive conflicts during the classroom discussion. English Education, 40(3), 231-255.

Early, J.S., \& Shagoury, R. (2010). Learning from the lived experiences of new language arts teachers working in diverse urban schools. Teaching and Teacher Education: An International Journal of Research and Studies, 26(4), 1049-1058.

Emerson, R.M., Fretz, R.I., \& Shaw, L.L. (2011). Writing ethnographic fieldnotes $\left(2^{\text {nd }}\right.$ ed.). Chicago, Illinois: University of Chicago.

Faircloth, B.S. (2009). Making the most of adolescence: Harnessing the search for identity to understand classroom belonging. Journal of Adolescent Research, 24(3), 321-348.

Faircloth, B.S. (2012). "Wearing a mask" vs. connecting identity with learning. Contemporary Educational Psychology, 37(3), 186-194.

Fecho, B., Graham, P., \& Hudson-Ross, S. (2005). Appreciating the wobble: Teacher 
research, professional development, and figured worlds. English Education, 37(3), 174-199.

Flores, M.A., \& Day, C. (2006). Contexts which shape and reshape new teachers' identities: A multi-perspective study. Teaching \& Teacher Education: An International Journal Of Research And Studies, 22(2), 219-232.

Flowerdew, J., \& Wang, S. H. (2015). Identity in academic discourse. Annual Review of Applied Linguistics, 35, 81-99.

Galda, L., \& Beach, R. (2001). Response to literature as a cultural activity. Reading Research Quarterly, 36(1), 64-73.

Gee, J. (2001). Identity as an analytic lens for research in education. Review of Research in Education, 25, (2000-2001), 99-125.

Gee, J. (2006). Self-fashioning and shape-shifting: Language, identity, and social class. In D.E. Alvermann, K.A. Hinchman, D.W. Moore, S.F. Phelps, \& D.R. Waff, (Eds.), Reconceptualizing the literacies in adolescents' lives, 165-186.

Gee, J. (2014). An introduction to discourse analysis: Theory and method. New York, NY: Routledge.

Gritter, K. (2012). Permeable textual discussion in tracked language arts classrooms. Research in the Teaching of English, 46(3), 232-259.

Glenn, W.J. \& Ginsberg, R. (2016). Resisting readers' identity (re)construction across English and young adult literature course contexts. Research in the Teaching of English, 51(1), 84-105.

Golding, W. (1954). Lord of the flies. London, UK: Faber and Faber. 
Hall, L.A. (2016). "I don’t really have anything good to say": Examining how one teacher worked to shape middle school students' talk about texts. Research in the Teaching of English, 51(1), 60-83.

Hall, L. (2012). The role of reading identities and reading abilities in students' discussions about texts and comprehension strategies. Journal of Literacy Research. 44(3), 239-272.

Hartman, S.V. (2016). Cultivating teacher agency: How teachers persist in the face of school mandates. English Journal, 106(2), 16-21.

Hess, D.E., \& McAvoy, (2014). The political classroom. New York, NY: Routledge.

Hinchman, K., \& Chandler-Olcott, K. (2006). Literacies through youth's eyes: Lessons in representations and hybridity. In Alvermann, D.E., Hinchman, K.A., Moore, D.W., Phelps, S.F., \& Waff, D.R. (Eds.), Reconceptualizing the literacies in adolescents' lives, 231-254.

Hinchman, K., \& Young, J.P. (2001). Speaking but not being heard: Two adolescents negotiate classroom talk about text. Journal of Literacy Research, 33(2), 243268.

Holland, D.C., Lachicotte Jr., W., Skinner, D., \& Cain, C. (2001). Identity and agency in cultural worlds. Cambridge, MA: Harvard University.

Holland, D., \& Lave, J. (2001). History in person: An introduction. In D. Holland \& J. Lave (Eds.), History in person: Enduring struggles, contentious practice, intimate identities (pp. 3-36). Santa Fe: NM, School of American Research Press. 
Juzwik, M.M., Nystrand, M., Kelly, S., \& Sherry, M.B. (2008). Oral narrative genres as dialogic resources for classroom literature study: A contextualized case study of conversational narrative discussion. American Educational Research Journal, 45(4), 1111-1154.

Kreber, C. (2010). Academics' teacher identities, authenticity and pedagogy. Studies in Higher Education, 35(2), 171-194.

Leander, K.M., \& Sheehy, M. (2004). Spatializing literacy research and practice. New York NY: Peter Lang.

LeCompte, M.D., \& Schensul, J.J. (2010). Designing and conducting ethnographic research. Walnut Creek, CA: Rowman Altamira.

Lewis, C. (1997). The social drama of literature discussions in a fifth/sixth-grade classroom. Research in the Teaching of English, 31(2), 163-204.

Lewis, C. (2001). Literacy practices as social acts. Mahwah, NJ: Lawrence Earlbaum.

Lewis, C., Encisco, P., \& Moje, E. (2007). Reframing sociocultural research on literacy. Mahwah, NJ: Lawrence Erlbaum.

Lewis, C., \& del Valle, A. (2008). Literacy and identity: Implications for research and practice. In L. Christenbury, R. Bomer, \& P. Smagorinsky, (Eds.), Handbook of adolescent literacy research (pp. 307-322). New York, NY: Guilford Press.

Malloy, J.A., Rogers, A. M., \& Cridland-Hughes, S. (2015). Keeping the mic on: Emboldening voices through discussion-based inquiry. English Journal, 105(2), 64-69.

Maloch, B., \& Bomer, R. (2012). Developing discussion. Language Arts, 90(2), 129-137. 
Marquez, G.G. (2007). Love in the time of cholera. New York, NY: Vintage.

Miller, S.M., Knips, M.A., \& Goss, S. (2013). Changing the game of literature with authentic assessment: The promise of multimodal composing. English Journal, 103(1), 88-94.

Moje, E., Luke, A., Davies, B., and Street, B. (2009). Literacy and identity: Examining the metaphors in history and contemporary research. Reading Research Quarterly. 44(4): 415-437.

Moore, D. W., \& Cunningham, J. W. (2006). Adolescent agency and literacy. In D.E. Alvermann, K.A. Hinchman, D.W. Moore, S.F. Phelps, \& D.R. Waff, (Eds.), Reconceptualizing the literacies in adolescents' lives, 129-146.

Nachowitz, M. (2015). How Sara got her voice back: The importance of tentativeness. English Journal, 105(1), 35-41.

Newell, G. E., Tallman, L., \& Letcher, M. (2009). A longitudinal study of consequential transitions in the teaching of literature. Research in the Teaching of English, 44(1), 89-126.

Nystrand, M., \& Gamoran, A. (1990). Student engagement: When recitation becomes conversation. In Waxman, H. \& Walberg, H. (Eds.), Contemporary research on teaching for the national society for the study of education, (pp. 1-28). Richmond, CA: McCutchan.

O'Connor, K.E. (2008). "You choose to care": Teachers, emotions and professional identity. Teaching And Teacher Education: An International Journal Of Research and Studies, 24(1), 117-126. 
Pace, B.G. (2006). Between response and interpretation: Ideological becoming and literacy events in critical readings of literature. Journal Of Adolescent \& Adult Literacy, 49(7), 584-594.

Pearce, J., \& Morrison, C. (2011). Teacher identity and early career resilience: Exploring the links. Australian Journal of Teacher Education, 36(1), 48-59.

Perry, K. (2009). Genre, contexts, and literacy practices: Literacy brokering among Sudanese refugee families. Reading Research Quarterly, 44(3), 256-276.

Pope, D.C. (2003). Doing school: How we are creating a generation of stressed-out, materialistic, and miseducated students. New Haven, CT: Yale University.

Rogers, R. (2002). "That's what you're here for, you're suppose to tell us": Teaching and learning critical literacy. Journal of Adolescent \& Adult Literacy, 45(8), 772-787.

Rowling, J.K. (1999). Harry Potter and the sorcerer's stone. New York, NY: Scholastic.

Rumenapp, J. C. (2016). Analyzing discourse analysis: Teachers' views of classroom discourse and student identity. Linguistics and Education, 35, 26-36.

Saldaña, J. (2015). The Coding Manual for Qualitative Researchers. Washington, D.C.: Sage.

Schappe, J.F. (2015). "Looking back I can see" literate tensions and changes: A veteran teacher's cross-analysis of his literate life. English Education, 47(3), 204-244.

Schieble, M. (2012). Critical conversations on Whiteness with young adult literature. Journal of Adolescent \& Adult Literacy, 56(3), 212-221.

Schieble, M., Vetter, A., \& Meacham, M. (2015). A discourse analytic approach to video analysis of teaching: Aligning desired identities with practice. Journal of Teacher 
Education, 66(3), 245-260.

Sherry, M.B. (2014). Indirect challenges and provocative paraphrases: Using cultural conflict-talk practices to promote students' dialogic participation in whole-class discussions. Research in the Teaching of English, 49(2), 141.

Skerrett, A. (2009). Biographical orientations to secondary English teaching within a mosaic context of diversity. English Education, 41(3), 281-303.

Skerrett, A. (2012). "We hatched in this class": Repositioning of identity in and beyond a reading classroom. High School Journal, 95(3), 62-75.

Sloan, K. (2006). Teacher identity and agency in school worlds: Beyond the all-good/all-bad discourse on accountability-explicit curriculum policies. Curriculum Inquiry, 36(2), 119-152.

Smagorinsky, P. (2008). Teaching English by design: How to create and carry out instructional units. Portsmouth, NH: Heinemann.

Smith, K. (2008). Becoming an "honours student": The interplay of literacies and identities in a high-track class. Journal Of Curriculum Studies, 40(4), 481-507.

Spector, K. (2010). Classroom provocateurs and ethical classroom practice. Changing English: Studies in Culture \& Education, 17(4), 363-373.

Sunstein, B.S., \& Chiseri-Strater, E. (2011). Fieldworking: Reading and writing research. New York, NY: Macmillan.

Sutherland. L.M. (2007). Black adolescent girls' use of literacy practices to negotiate boundaries of ascribed identity. Journal of Literacy Research. 37(3), 365-406. 
Thein, A.H. (2009). Identifying the history and logic of negative, ambivalent, and positive responses to literature: A case-study analysis of cultural models. Journal of Literacy Research. 41, 273-316.

Thein, A.H., Guise, M., \& Sloan, D.L. (2011). Problematizing literature circles as forums for discussion of multicultural and political texts. Journal of Adolescent \& Adult Literacy, 55(1), 15-24.

Thein, A.H., Guise, M., \& Sloan, D.L. (2012). Exploring the significance of social class identity performance in the English classroom: A case study analysis of a literature circle discussion. English Education, 44(3), 215-253.

Thein, A.H., Guise, M., \& Sloan, D.L. (2015). Examining emotional rules in the English classroom: A critical discourse analysis of one student's literary responses in two academic contexts. Research in the Teaching of English, 49(3), 200.

Valenzuela, L. (1988). The censors. Willimantic, CT: Curbstone Press.

Van Allsburg, C. (2015). The mysteries of Harris Burdick. New York, NY: Houghlin Mifflin Harcourt.

Vetter, A. (2010). Positioning students as readers and writers through talk in a high school English classroom. English Education, 43(1), 33-64.

Vygotsky, L.S. (1978). Mind and society. Cambridge, MA: Harvard University.

Wortham, S. (2006). Learning identity: The joint emergence of social identification and academic learning. Cambridge, MA: University Press.

Wortham, S. (2001). Teachers and students as novelists: Ethical positioning in literature discussions. Journal of Adolescent \& Adult Literacy, 45(2), 126-137. 
Zhang, J., Niu, C., Munawar, S., \& Anderson, R.C. (2016). What makes a more proficient discussion group in English language learners' classrooms? Influence of teacher talk and student backgrounds. Research in the Teaching of English, 51(2), $183-208$. 


\section{Appendix A: Teacher Interview Protocol}

\section{Interview 1}

I. Background Information
a. Teacher as learner
b. Teacher in preparation program
c. Teacher in classroom
d. Teacher outside of classroom

II. Class context
a. Tracking
b. Students
c. Goals for year
d. Current curriculum plans

\section{Interview 2}

I. Specific Students
a. Classroom work
b. Goals
c. Changes as year progresses

\section{Interview 3-5}

I. Progress throughout the year
a. Changes in curriculum
b. Relationship to students
c. Relationship to administration

II. Attitudes toward literacy learning
a. Progress made
b. Hindrances
c. Student examples 


\section{Appendix B: Student Interview Protocol}

\section{Interview 1}

1. How do you feel about English class?

2. What do you do in Mr. Stark's classroom?

3. How would you describe Mr. Stark as a teacher?

4. How do you see Mr. Stark compared to other teachers?

5. Tell me about your favorite moment in Mr. Stark's classroom so far.

\section{Interview 2}

I. Time as student in Mr. Stark's classroom

a. How have you changed

b. How have you learned

c. Favorite moment now

d. How does your learning in this classroom compare to past/current classes

II. Mr. Stark throughout the year

a. Did Mr. Stark change as a teacher?

b. How did work in classroom help with literacy learning

c. What will you miss the most

d. What else do you want to tell me 


\section{CURRICULUM VITAE}

Ashley Shelton Arnold, Ph.D.

Curriculum and Instruction, Literacy Education

College of Education and Human Development

Department of Middle and Secondary Education

University of Louisville

Louisville, Kentucky | 40292

ashley.shelton@louisville.edu | 852-3041

\section{EDUCATION}

University of Louisville, Louisville KY

Ph.D. in Curriculum and Instruction, Literacy Education

Dissertation: "It Teaches Them How to Handle a Conversation in the Real

World": An Analysis of How Identity Performances Shape Classroom Discussions

Committee: Dr. James Chisholm (chair), Dr. Penny Howell (co-chair),

Dr. Lori Norton-Meier, and Dr. Andrea Olinger

Murray State University

Alternative Certification

London Metropolitan University

M.A. in English

Southern Illinois University Edwardsville

B.A. in English, B.S. in Biological Sciences

\section{PUBLICATIONS}

Chisholm, J.S., Shelton, A.L., \& Sheffield, C.C. (2017). Mediating emotive empathy with informational text: Three middle school students' think-aloud protocols of Gettysburg: The Graphic Novel. Journal of Adolescent and Adult Literacy, 61(3), 289298.

Sheffield, C.C. \& Shelton, A. L. (2017). Power, authority, guides: Slavery in Mammoth Cave. Middle Level Learning, 58, 2-14. 
Howell, P.B., Sheffield, C.C., Shelton, A., \& Vujaklija, A.R. (2017). Backchannel discussions during classroom observations: Connecting theory and practice in real time. Middle School Journal, 48(2), 24-30.

Chisholm, J.S. \& Shelton, A.L. (2016). Backchanneling technology: Transforming students' participation during discussions of If I Grow Up. The ALAN Review, 43(3), 2234.

Chisholm, J.S., Whitmore, K.F., Shelton, A.L., McGrath, I.V. (2016). Moving interpretations: Using drama-based arts strategies to deepen learning about The Diary of a Young Girl. English Journal, 105(5): 35-41.

\section{UNDER REVIEW/IN PREPARATION}

Shelton Arnold, A., \& Chisholm, J.S. (in preparation). Introduction to multimodal literacy in the $21^{\text {st }}$ century. In C.C. Sheffield, From a cacophony of information to a symphony of meaning: Embracing multimodal literacy within Social Studies education. Silver Spring, MD: National Council for the Social Studies.

Shelton, A.L., Sheffield, C.C., \& Chisholm, J.S. (in preparation). From image to inference: Three eighth grade students' meaning making with an informational historythemed graphic novel.

Shelton, A.L. (in preparation). "There's no limitation to imagination": Multimodally composed artifacts and identity play.

Shelton, A.L. (in preparation). Writing as a superpower: Negotiating emotion in composing academic texts.

\section{EVALUATION REPORTS}

Chisholm, J.S., Whitmore, K.F., Shelton, A., McGrath, I., \& Ousley, C. (May, 2015). Anne Frank: Bearing Witness. Executive Summary and Evaluation Report submitted to Jeffrey Jamner, Senior Director, School Programs, The Kentucky Center for the Performing Arts.

\section{PRESENTATIONS}

Sheffield, C.C., Chisholm, J.S., \& Shelton, A.L. (accepted). Caring for the past: Mobilizing emotive empathy with an informational graphic novel. Paper accepted for the 2017 College and University Faculty Assembly Conference: San Francisco, CA.

Sheffield, C.C., Shelton, A.L. \& Chisholm, J.S., (February, 2017). Eighth-grade 
students' meaning making with an informational history-themed graphic novel. Paper presented at the 2017 International Society for the Social Studies Conference. Orlando, FL.

Shelton, A.L. (November, 2016). “There's no limitation to imagination": Multimodally composed artifacts and identity play. Paper presented at the L. Ramon Veal Research Roundtable of the Annual Meeting of the National Council of Teachers of English, Atlanta, GA.

Chisholm, J.S., Sheffield, C.C., \& Shelton, A.L. (November, 2016). Mobilizing emotive empathy with informational text: Three middle school students' think-aloud protocols of Gettysburg: The Graphic Novel. Presentation at the Literacy Research Association Conference. Nashville, TN.

Chisholm, J.S., Whitmore, K.F., Shelton, A.L., \& Baize, J.P. (November, 2016). Visual, embodied, and empathetic literacies: Research methods to understand how adolescents see, become, and feel challenging texts. Presentation at the Literacy Research Association Conference. Nashville, TN.

Whitmore, K. F., Chisholm, J. S., Joiner, K., Whitaker, F., Shelton, A., \& McGrath, I. (November, 2016). Using arts-based strategies to teach The Diary of A Young Girl. Presentation at the Annual Meeting of the National Council of Teachers of English, Atlanta, GA.

Sheffield, C.C., Howell, P.B. \& Shelton, A.L. (April, 2016). Tablet-mediated embedded classroom observations in early teacher preparation. Presentation at the Professional Development School National Conference, Orlando, FL.

Sheffield, C.C. \& Shelton, A.L. (February, 2016). "Dude, the pictures actually help!" Middle grades student engagement with and perception of history-themed graphic novels. Presentation at the International Society for the Social Studies Conference, Orlando, FL.

Sheffield, C.C., Howell, P.B. \& Shelton, A.L. (November, 2015). Tablet-mediated synchronous course-embedded classroom observation in early teacher preparation experiences. Presentation at College and University Faculty Assembly of the National Council for the Social Studies Conference. New Orleans, LA.

Shelton, A.L. (October, 2015). "I'm me": One teacher's negotiation of self through talk. Presentation at the Grounded Theory Institute Seminar. Mill Valley, CA.

Howell, P.B., Sheffield, C.C., Shelton, A.L., \& Vujaklija, A. (March, 2015). Moving past just sitting in the back: tablet-mediated synchronous classroom observations in teacher preparation. Presentation at the society for information technology and teacher education annual conference. Las Vegas, NV. 
Chisholm, J.S., Whitmore, K.F., McGrath, I.V., \& Shelton, A.L. (February, 2015). Using arts-based literacies to develop, embody, and transmediate empathy in middle grades ELA classrooms. Presentation at Journal of Language and Literacy Education at University of Georgia Winter Conference. Athens, Georgia.

\title{
REGIONAL, STATE, \& LOCAL
}

Shelton, A.L. (March 2016). An introduction to grounded theory. Presentation at University of Louisville, ELFH 606: Program Evaluation. Louisville, KY. (Invited).

Shelton, A. L., \& Thornburgh, W. R. (February, 2015). Building bridges: Literacy in the science classroom. Presentation at the Hoosier Association of Science Teachers, Inc. Conference. Indianapolis, IN.

Thornburgh, W. R. \& Shelton, A. L. (November, 2014). Science, technology, and literacy...oh my! Presentation at the Kentucky Science Teachers Association Conference. Lexington, $\mathrm{KY}$.

\section{TEACHING EXPERIENCE}

\section{University of Louisville}

Department of Middle and Secondary Education

\section{Instructor}

Courses Taught:

Reading and Writing Across the Curriculum

Exploring Teaching P-12

Advanced Reading Methods (online, M.Ed. program)

General Methods (spring 2018)

Public Schools in America (spring 2018)

Graduate Research \& Teaching Assistant

2014-2017

Teaching Assistant:

English Methods

Courses Taught:

Teaching Adolescent Readers

English Capstone Seminar

Reading and Writing Across the Curriculum

\author{
West Kentucky Community and Technical College \\ Department of English \\ Part Time Faculty \\ Courses Taught: \\ Writing I (face-to-face \& online)
}

2012-2014 
Writing II (face-to-face \& online)

Shawnee Community College

Department of English

Part Time Faculty

$2011-2013$

Courses Taught:

Basics of College Reading and Writing

Fundamentals of College Writing

English Composition I

English Composition II

St. Mary High School, Paducah, Kentucky

2012-2014

Secondary English Teacher

\section{GRANTS \& AWARDS}

School of Interdisciplinary and Graduate Studies Student Spotlight

CEHD Research and Faculty Development Grant $(\$ 1,468)$

2015

School of Interdisciplinary and Graduate Studies Grant Writing Academy 2015

PROFESSIONAL SERVICE (UNIVERSITY OF LOUISVILLE)

You've Got the Write One Summer Enrichment Camp

2018

Co-Director

Teach Kentucky

2017

Transcript Reviewer

B.S. Program Advisor

2017

Research Fund Committee, Graduate Student Council

2016-2017

Member

Middle and Secondary Education Representative

2015-2017

Graduate Student Council

You've Got the Write One Summer Enrichment Camp

2016, 2017

Writing Specialist

You've Got the Write One Summer Enrichment Camp

Lead Teacher 
Paul Weber Award Selection Committee

Member

Spring Research Conference

2014-2015

Site Co-Chair

\section{PROFESSIONAL EXPERIENCE}

Summerbridge Louisville

2016, 2017

(invited)

Leader, Professional Development

Literacy Research Association Conference

2015, 2016

Reviewer

Anne Frank: Bearing Witness Project

Jewish Heritage Fund for Excellence

2015

Co-Evaluator

Middle and Secondary Education

2015-2017

Recruitment Coordinator

\section{PROFESSIONAL ASSOCIATIONS}

National Council of Teachers of English

- Assembly on Literature for Adolescents

Literacy Research Association

International Literacy Association 